SMART WALL PLUG DESIGN FOR THE DC HOUSE PROJECT

\author{
A Thesis \\ Presented to \\ The Faculty of California Polytechnic State University, \\ San Luis Obispo \\ In Partial Fulfillment \\ Of the Requirements for the Degree of \\ Master of Science in Electrical Engineering
}

By

Edward Constant Sibal

December 2012 
(C) 2012

Edward Constant Sibal

ALL RIGHTS RESERVED 


\section{COMMITTEE MEMBERSHIP}

TITLE:

SMART WALL PLUG DESIGN FOR THE DC HOUSE PROJECT

AUTHOR: $\quad$ Edward Constant Sibal

DATE SUBMITTED: December 2012

COMMITTEE CHAIR: Dr. Taufik, Professor

COMMITTEE MEMBER: Dr. Ahmad Nafisi, Professor

COMMITTEE MEMBER: Dr. Xiao-Hua (Helen) Yu, Professor 


\title{
ABSTRACT \\ SMART WALL PLUG DESIGN FOR THE DC HOUSE PROJECT
}

\author{
Edward Constant Sibal
}

The DC House project at Cal Poly State University faces a challenge of supplying DC voltage to household appliances. Each appliance in the DC House constitutes a DC load that has a unique voltage and power rating, hence the need to develop a smart DC wall plug that will automatically adjust to the operating voltage required by any DC load. This thesis entails a proof of concept design of the smart DC wall plug which can automatically detect an appliance's voltage rating. The design employs a dc-dc converter in conjunction with a microcontroller to sense load current to properly adjust the required load voltage. Hardware implementation to demonstrate the functionality of the smart wall plug was developed. Results performed on several dc loads show that the smart wall plug is able to adjust to the required load voltage within an acceptable range. An algorithm to improve the accuracy was attempted and presented along with the results. Further recommendations to improve the current design will also be discussed. 


\section{ACKNOWLEDGMENTS}

I would like to personally thank my mother, Daisy, for believing in me that I can make my dreams happen. Through personal and economic hardships with my mother, I want to dedicate all my hard work to her. I also want to thank my Mama Lita, Papa Martin, and Brian Horton for financially supporting me through college. I would like to thank my sister Simmonne, extended family, and friends for the physical and emotional support through my college experience. Lastly, I would like to acknowledge my Thesis Advisor, Taufik, for

inspiring me to use my passion in Engineering to help others and leading me the path to success. My success would not be possible without these people. 


\section{TABLE OF CONTENTS}

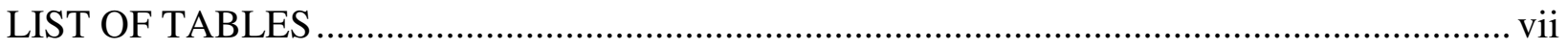

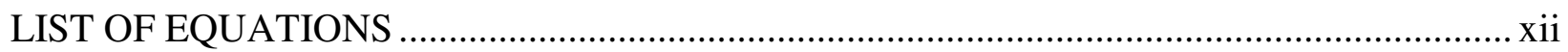

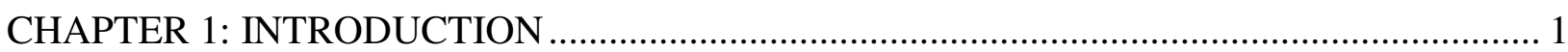

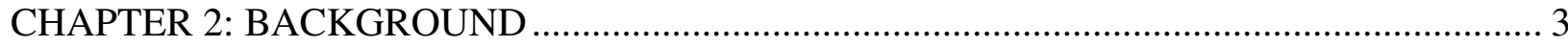

2.1 - The Motivation for a DC House ............................................................................. 3

2.2 - The Proposal for a DC System in Houses \& Buildings ............................................... 3

2.3 - The Proposal for a DC System for Data Centers .................................................. 4

2.4 - The Proposal for Electrical Plugs and Outlets for the DC System............................... 5

2.5 - Phase 1 for the Wall Outlet Plug for the DC House Project .......................................... 7

CHAPTER 3: DESIGN CONSTRAINTS \& REQUIREMENTS ........................................ 9

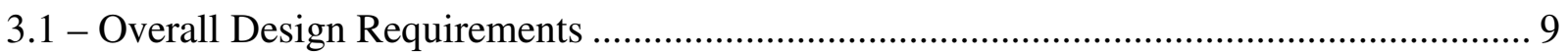

3.2 - Output Voltages Constraints ................................................................................ 10

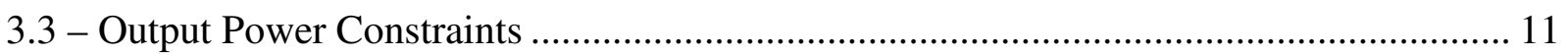

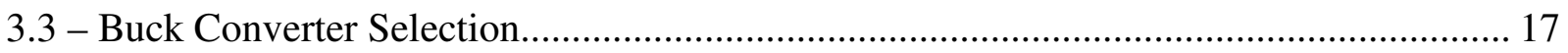

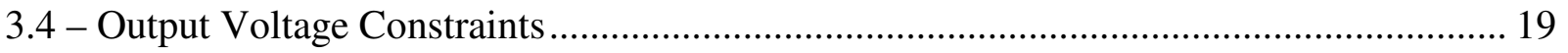

3.5 - Microcontroller Selection: The Arduino Uno .............................................................. 22

3.6 - Digital Potentiometer Selection: AD5206........................................................... 24

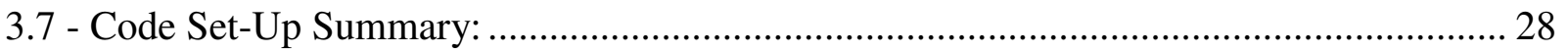

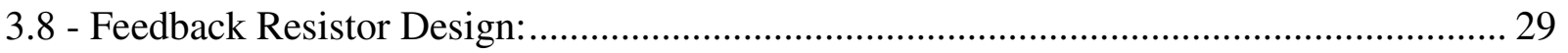

CHAPTER 4: DEVELOPMENT \& TESTING .................................................................... 33

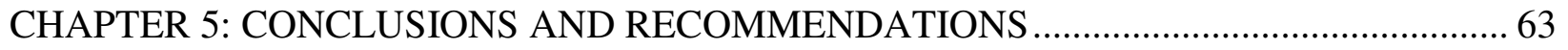

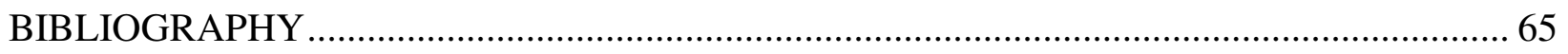

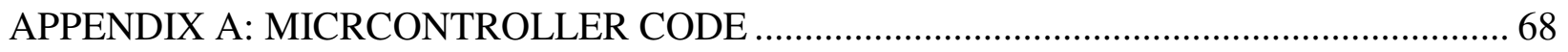

APPENDIX B: FLOWCHARTS FOR METHOD \#1, \#2, \#3, \& \#4 ....................................... 78 


\section{LIST OF TABLES}

Table 3-1: Initial Design for Output Voltage \& Power Ratings ..................................................... 12

Table 3-2: Cell Phone Charger Voltage \& Power Ratings ............................................................. 12

Table 3-3: Tablet Voltage \& Power Ratings.................................................................................. 12

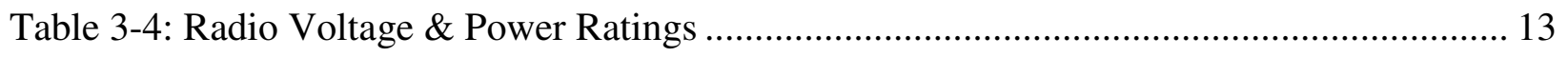

Table 3-5: DC Fan Voltage \& Power Ratings ...................................................................... 13

Table 3-6: DC TV Voltage \& Power Ratings .............................................................................. 13

Table 3-7: DC Refrigerators Voltage \& Power Ratings .............................................................. 14

Table 3-8: Laptop Charger Voltage \& Power Ratings............................................................... 14

Table 3-9: Vmax, Vmin, Vtyp ratings for each appliance .......................................................... 15

Table 3-10: DC Wall Outlet Possible Design Requirements Layout ........................................... 21

Table 3-11: Final Design Requirements for the DC Wall Outlet .................................................. 21

Table 3-12: Output Resistance Values when $V_{B}=0 \mathrm{~V}$ and Terminal $A=$ Open Circuited [26] 25

Table 3-13: Output Resistance Values when $\mathrm{V}_{\mathrm{A}}=0 \mathrm{~V}$ and Terminal $\mathrm{B}=$ Tied to Wiper $\mathrm{W}$ [26]25

Table 3-14: Hardware Connections from the Arduino Board to the Digital Potentiometer......... 27

Table 3-15: Hardware Connections from the AD5206 Chip to the Breadboard ........................... 28

Table 3-16: Hardware Connections from the AD5206 to the LM5117 …………………….......... 28

Table 3-17: Expected Calculations for $\mathrm{R}_{\mathrm{FB} 1}$ when given $\mathrm{R}_{\mathrm{FB} 2}$ \& Vout ........................................ 31

Table 3-18: Summary of Design Requirements for the Smart Wall Plug .................................... 32

Table 3-19: Summary of Components Used for Hardware Implementation to Construct the

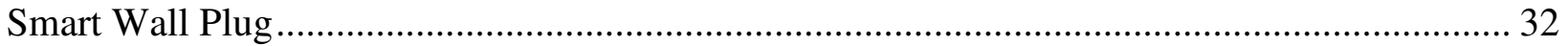

Table 4-1: Measured Output Resistance Values from the AD5206 ............................................ 34

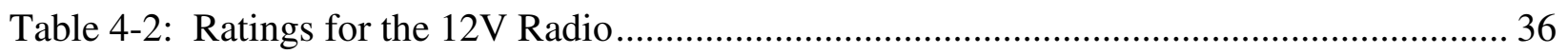

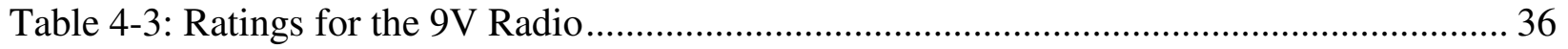

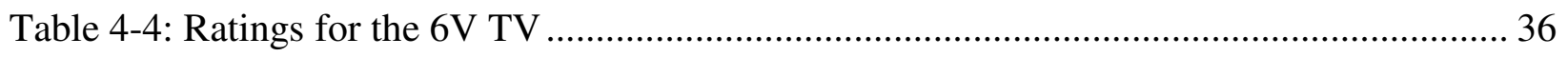

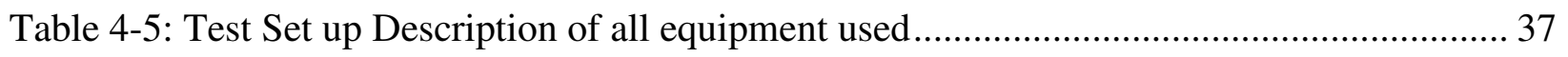

Table 4-6: Different of methods that make up the output voltage's behavior ............................... 39

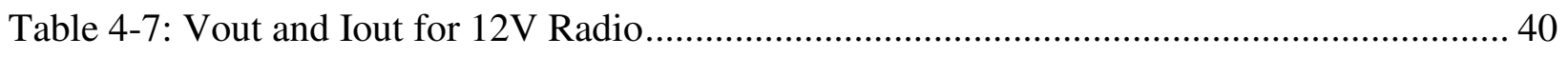

Table 4-8: Vout and Iout Data for 9V Radio .......................................................................... 42

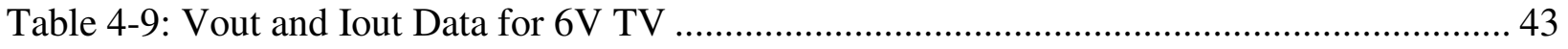




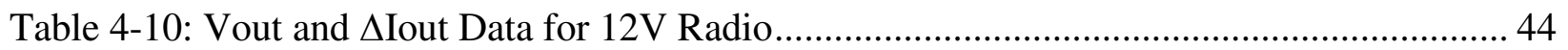

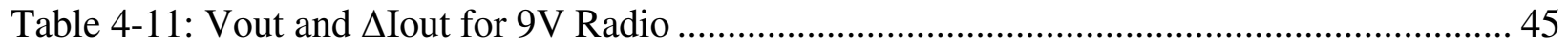

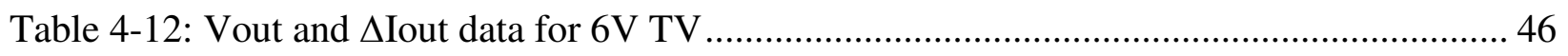

Table 4-13: Current monitor digital output for 12V radio for 10 trials: ......................................... 49

Table 4-14: Current monitor digital output for 9V radio for 10 trials: ........................................ 49

Table 4-15: Current monitor digital output for 6V TV for 10 trials: ............................................ 50

Table 4-16: Example of when 9V Radio does not meet its voltage ratings..................................... 50

Table 4-17: Difference in current monitor voltages between 6.74V and 7.12V ......................... 50

Table 4-18: Example of when 9V Radio does meets its voltage ratings ...................................... 51

Table 4-19: Difference in current monitor voltages between $8.59 \mathrm{~V}$ and $9.22 \mathrm{~V}$........................... 51

Table 4-20: Wall Plug Voltages for the 12V radio, 9V radio, and 6V TV results ........................ 51

Table 4-21: Current Monitor Readings for Chosen Output Voltage (4.03V) for 6V TV ............. 53

Table 4-22: Current Monitor Readings for Decreased Output Voltage (3.24V) for 6V TV ........ 53

Table 4-23: Current Monitor Differences (Results) from Table 4-20 and Table 4-21 for 6V TV 53

Table 4-24: Mathematical Results from Table 4-22 to obtain the lowest number ......................... 54

Table 4-25: Current Monitor Readings for Chosen Output Voltage (4.03V) for 6V TV .............. 54

Table 4-26: Current Monitor Readings for Decreased Output Voltage (4.51V) for 6V TV ........ 54

Table 4-27: Current Monitor Differences (Results) from Table 4-24 and Table 4-25 for 6V TV 54

Table 4-28: Mathematical Results from Table 4-26 to obtain the lowest number ........................ 55

Table 4-29: Lowest number comparison for two different voltages.............................................. 55

Table 4-30: Previous and Next Voltage Comparisons for 3 Iterations for the 12V Radio (Trial 1)

Table 4-31: Previous and Next Voltage Comparisons for 3 Iterations for the 12V Radio (Trial 2)

Table 4-32: Previous and Next Voltage Comparisons for 3 Iterations for the 12V Radio (Trial 3)

Table 4-33: Previous and Next Voltage Comparisons for 3 Iterations for the 12V Radio (Trial 4)

Table 4-34: Previous and Next Voltage Comparisons for 3 Iterations for the 12V Radio (Trial 5)

Table 4-35: Previous and Next Voltage Comparisons for 3 Iterations for the 9V Radio (Trial 1) 
Table 4-36: Previous and Next Voltage Comparisons for 3 Iterations for the 9V Radio (Trial 2)

Table 4-37: Previous and Next Voltage Comparisons for 3 Iterations for the 9V Radio (Trial 3) 58

Table 4-38: Previous and Next Voltage Comparisons for 3 Iterations for the 9V Radio (Trial 4)

Table 4-39: Previous and Next Voltage Comparisons for 3 Iterations for the 9V Radio (Trial 5)

Table 4-40: Previous and Next Voltage Comparisons for 3 Iterations for the 6V TV (Trial 1)... 59

Table 4-41: Previous and Next Voltage Comparisons for 3 Iterations for the 6V TV (Trial 2)... 59

Table 4-42: Previous and Next Voltage Comparisons for 3 Iterations for the 6V TV (Trial 3)... 60

Table 4-43: Previous and Next Voltage Comparisons for 3 Iterations for the 6V TV (Trial 4)... 60

Table 4-44: Previous and Next Voltage Comparisons for 3 Iterations for the 6V TV (Trial 5)... 61 


\section{LIST OF FIGURES}

Figure 2-1: Proposed Architecture for DC System [19] .................................................. 4

Figure 2-2: Pspice Circuit for Analyzing a Plug and an Outlet Connected to a DC Distribution

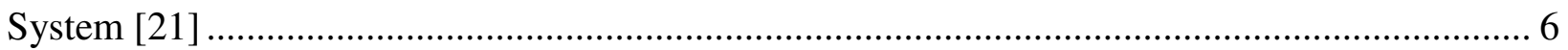

Figure 2-3: Pspice Circuit for Analyzing a Plug and an Outlet with a Protection Device [21]...... 6

Figure 2-4: Phase 1 DC Wall Plug System Block Diagram [8] ............................................... 7

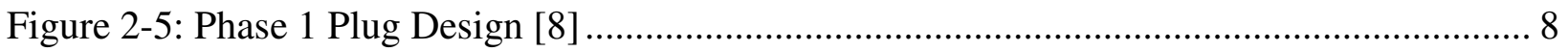

Figure 3-1: Block Diagram for the Wall Outlet................................................................ 10

Figure 3-2: Graphical Representation for Different Input Voltage Ratings (Vmin, Vtyp, Vmax)

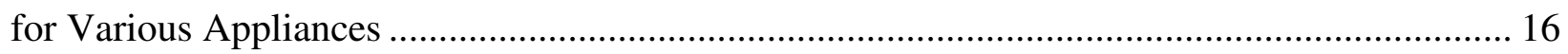

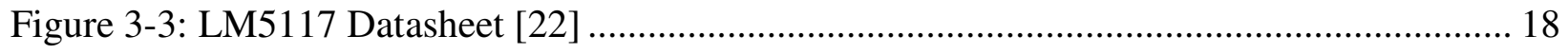

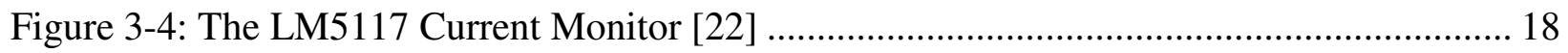

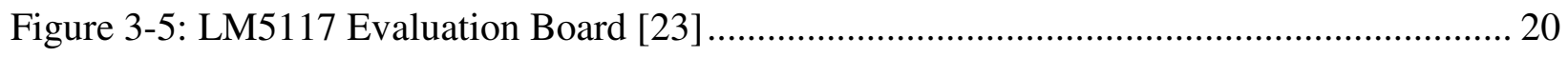

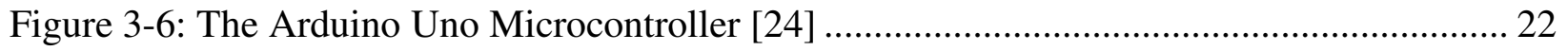

Figure 3-7: Arduino Uno Specifications for AnalogRead() function [25] .............................. 23

Figure 3-8: Arduino Hardware Connections to the Digital Potentiometer (AD5206)................ 25

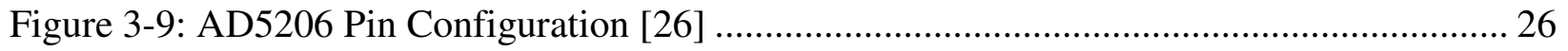

Figure 3-10: AD5206 Pin Function Descriptions [26] .......................................................... 27

Figure 3-11: SPI Code Initialization and Digital Potentiometer Functionality [27].................. 29

Figure 3-12: Output Resistor Divider $\left(\mathrm{R}_{\mathrm{FB} 2 \&} \mathrm{R}_{\mathrm{FB} 1}\right)$ [23] ................................................. 30

Figure 4-1: R16 Connection with the Potentiometer (Positive Terminal as white wire and

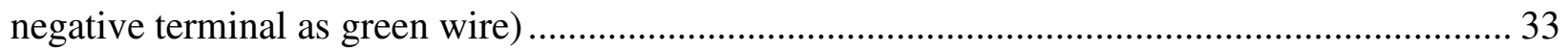

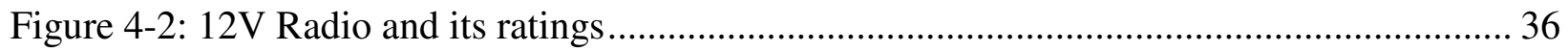

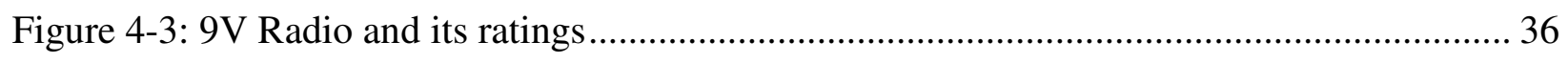

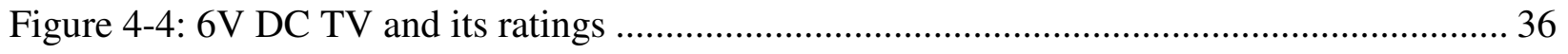

Figure 4-5: Overall Test Set up for DC Wall Plug ........................................................... 37

Figure 4-6: Close up \& Side View of the test set up for the Radio, LM5117, Arduino Uno and

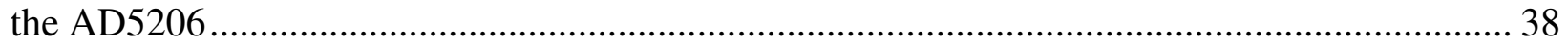

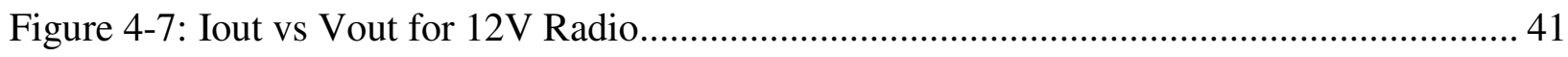

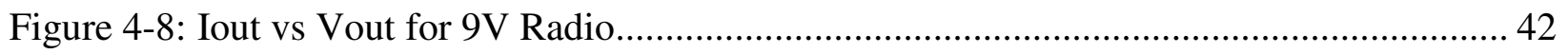

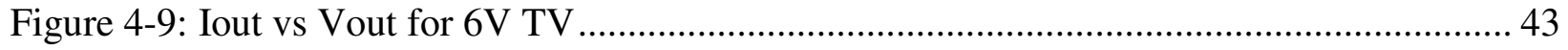


Figure 4-10: $\Delta$ Iout vs Vout for 12V Radio .......................................................................... 45

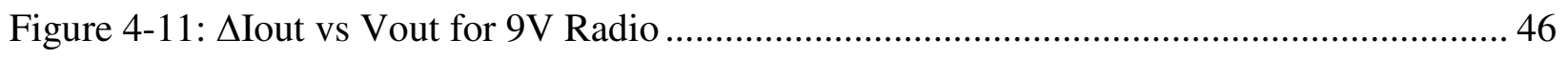

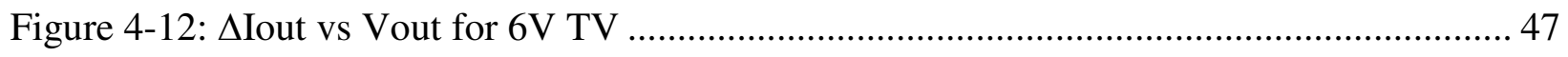




\section{LIST OF EQUATIONS}

Equation 3-1: Power Calculation to Determine Output Power.............................................. 11

Equation 3-2: Current Calculation to Determine Output Current.............................................. 11

Equation 3-3: Average Voltage Calculation from the Current Monitor ................................... 19

Equation 3-4: Calculation for Compensation Resistor ...................................................... 30

Equation 3-5: Feedback Resistor Divider 2 and 1 Determine the Output Voltage..................... 31

Equation 4-1: Difference Calculation between Two Currents for Two Output Voltages ........... 44 


\section{CHAPTER 1: INTRODUCTION}

The DC House is an open source project that consists of various senior projects and master theses that involve different components that make up the DC House. The DC House is

powered by renewable energy sources such as photovoltaic generation, wind power generation, and hydro-electric generation, as well as human-powered generation. These sources will eventually power up DC appliances inside the DC House.

The DC house project started in 2010 where system and design was crucial to oversee the whole project and to show that it was possible to design a DC house. Phase 1 (AY 2010-2011) included projects focusing on DC House modeling and system design [1], distribution system and load design [2], followed by DC generation projects such as photovoltaic generation, wind power generation, hydro-electric generation, and bicycle power generation [3] - [6]. Also, a design for multi-input single-output (MISO) DC-DC converter design was important as the interface between different DC sources to the DC house [7]. A fixed voltage DC wall outlet was also implemented so that appliances can be powered up by the DC sources [8]. Continuous efforts to improve the DC house were conducted in Phase 2 (AY 2011-2012). Examples are design improvements of the MISO converter [9], and the fixed voltage DC wall outlet [10]. Additional methods of DC power generation were investigated such as a seesaw human-powered generator [11], and car alternator modification for low rpm generator was also initiated [12]. An actual construction of the DC house was modeled and built [13], along with its main load including the 48 V DC light-bulb [14] and a 48-V cell phone charger [15]. Phase 3 (AY 20122013) will focus more on field testing of the DC House generation systems and a DC-DC interface for household appliances [16]. In the end, a complete DC House system model will be 
presented to the public and eventually DC house demonstration unit will be constructed in several countries around the world.

Many efforts have gone towards the DC house project with many challenges yet to address and answer. One of the challenges is matching the main DC bus used to connect the energy sources to the DC House with the loads inside the DC house. The main DC bus uses 48 Volts, but the loads (household appliances) require different voltages. It would be inefficient to create a unique individual converter, and hence wall plug, for each specific load. The much better approach instead would be to implement a universal de wall plug with one output which can "smartly" adjust to any dc voltage level required by the dc load. Essentially, this 'smart' wall plug will be a dc-dc converter providing the 'smart' wall plug for the DC house enabling power to be provided from a single main $48 \mathrm{~V}$ dc bus to various dc voltage appliances.

The need for an efficient wall plug for the DC House is important and therefore this thesis will explore the initial design for the 'smart' wall plug. The main goal of this thesis is to provide a proof-of-concept design for automating a DC-DC converter (wall plug outlet) to vary an output voltage for a specific appliance employing a buck converter module and a microcontroller as the two main components. The smart de wall plug proposed in this thesis will serve as an improvement to the previous design the user manually change the output voltage of the wall plug to obtain the proper voltage for the load [8]. 


\section{CHAPTER 2: BACKGROUND}

\section{1 - The Motivation for a DC House}

The DC House project is a humanitarian effort to provide affordable energy to the unfortunate people living in areas that do not have access to electrical power. Many people in the third world countries such as Africa and South Asia live without electricity and continue to rely on wood, coal, or even dung to heat and cook in their homes [17]. These methods of burning wood, coal, and dung are a huge problem because they cause pollution within the house and therefore kill 1.6 million people a year due to unsanitary conditions [17]. Since the AC grid infrastructure is expensive and not available to them, a solution is to build a DC house that relies

on renewable energy sources, and hence can eliminate pollution and unsanitary conditions. Also, the International Energy Agency estimates by 2030, the Earth's population will likely top 8 billion, and 1.3 billion people will lack electricity [18]. The need for electricity is crucial as the population increases, so a DC House is needed because it is cost efficient and will provide a safe and a healthy environment for all.

\section{2 - The Proposal for a DC System in Houses \& Buildings}

Although most buildings and houses are powered by AC, it is not uncommon that DC distribution can be considered as a power source. To eliminate the additional efficiency losses, a DC system architecture for a house was proposed [19]. Instead of connecting DC sources (e.g. photovoltaics and fuel cells) to the AC infrastructure, the DC sources are connected to one common DC bus. All DC loads (appliances) are then connected to the common DC bus where the DC bus serves as input voltages for the DC loads. In addition, the house is still being powered by AC power, so AC power is converted to DC power and then connected to the 
common DC bus as well. The proposed architecture DC system is shown in Figure 2-1. This research develops the idea for the creation of the DC house since all DC loads will be powered by a $48 \mathrm{~V}$ common bus. The only difference between the DC system proposal and the DC house is that the DC house will not be supplied by AC power.

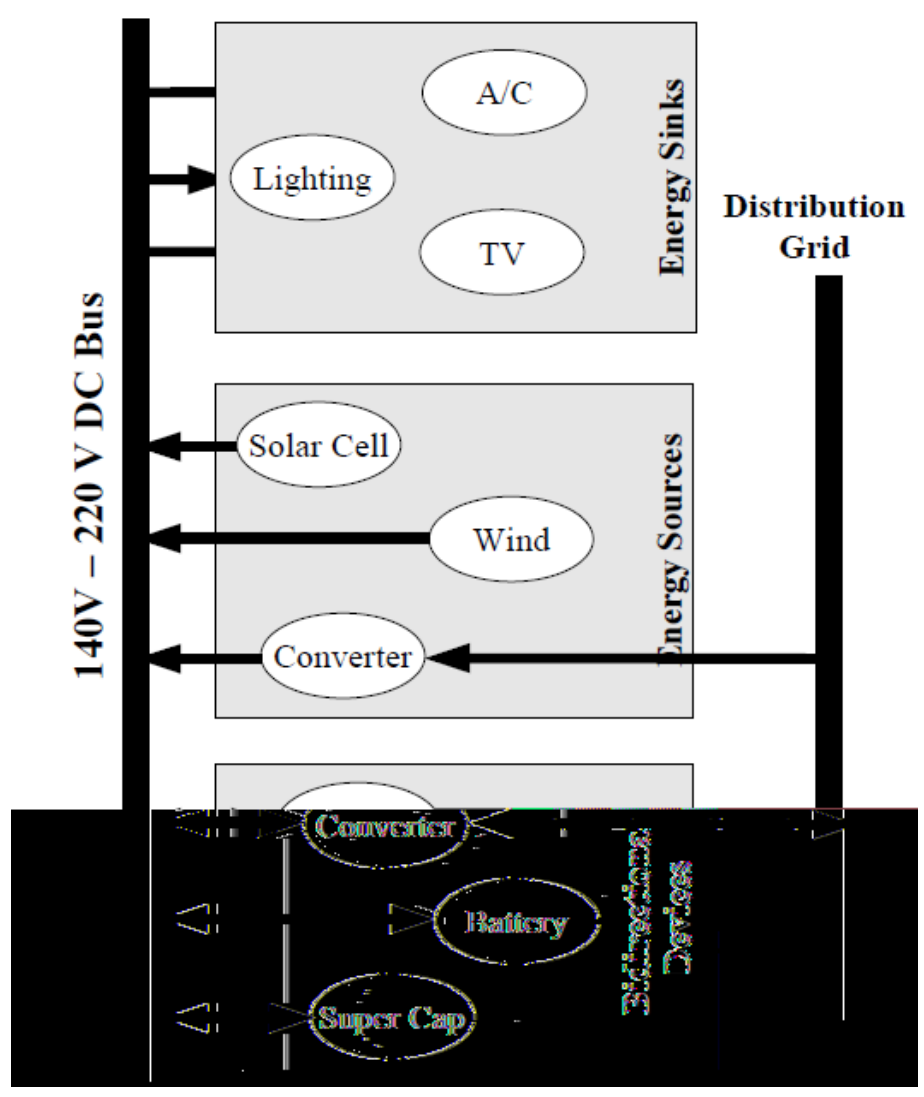

Figure 2-1: Proposed Architecture for DC System [19]

\section{3 - The Proposal for a DC System for Data Centers}

Not only was a DC System proposed for houses and buildings, Schneider Electric, a global specialist company in energy management, proposed a DC distribution system for data centers [20]. The DC distribution system will mainly be used within the server racks, where typically AC to DC conversion occurs in the power supply to distribute DC power within the 
rack. In this case, by using a DC distribution system, it can bypass AC and directly convert from DC to DC within the rack. This type of configuration improves the efficiency for power conversion and gives rise to a corresponding reduction in heat generation in the rack of approximately $1.5 \%$ [20]. The switch from the AC-DC converters to a DC-DC distribution system will reduce the size of the power supplies by approximately $20 \%$, which increases $3 \%$ of space in a rack [20]. Overall, the DC system for the racks is essential to use because power conversion efficiency is improved, heat generation is reduced, and the option allows for more available space in the racks.

\section{4 - The Proposal for Electrical Plugs and Outlets for the DC System}

Because DC systems are being proposed in houses and buildings, electrical plugs and outlets are necessary to interface the DC source to DC loads or appliances. Therefore, DC electrical plugs and outlets are being proposed in buildings for DC distribution systems. The plug and outlet are necessary parts to make the implementation of a DC voltage system [21]. In this proposal, the electrical plug and outlet is modeled by a circuit simulated in PSpice shown in Figure 2.2. The DC distribution system is modeled as a voltage source (outlet) and then connected to a resistor and an inductor, which represent the transmission line losses. This is then connected by the plug, which is modeled as double-pole single-throw switch and lastly connected to the load, which consists of a resistor and an inductor. A pulse voltage train is also connected to the plug, so it can simulate the effect of turning on and off the switch/plug. Furthermore, the simulation is to show the behavior of a DC wall plug when it is functioning directly with a DC distribution system. Results show that DC voltage transfer from the outlet (source) to the plug (load) is effective only if a protection circuit is present since the switch is 
interfaced with high voltage shown in Figure 2.3. Overall, the simulation proves a concept that a DC wall plug can be designed and created.

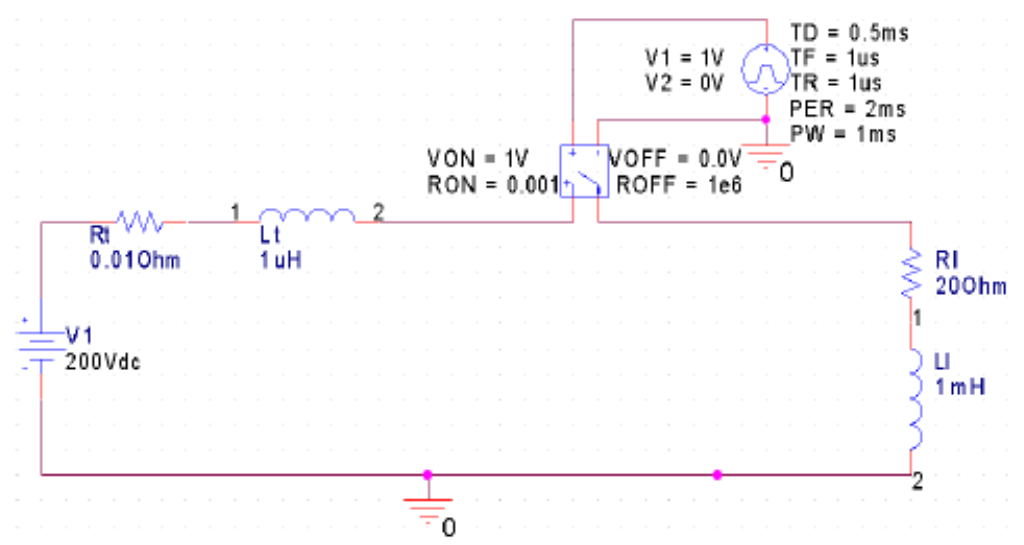

Figure 2-2: Pspice Circuit for Analyzing a Plug and an Outlet Connected to a DC Distribution System [21]

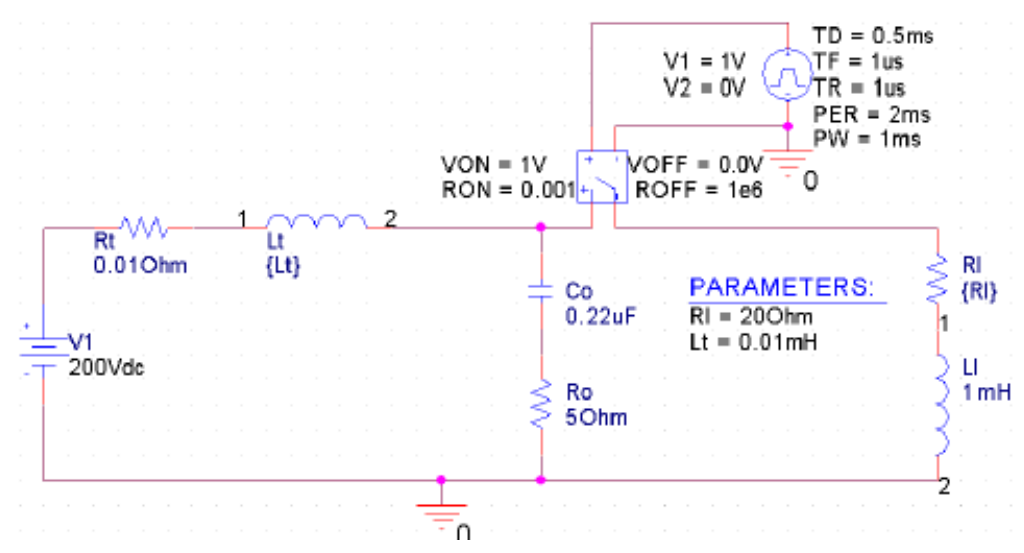

Figure 2-3: Pspice Circuit for Analyzing a Plug and an Outlet with a Protection Device [21] 


\section{5 - Phase 1 for the Wall Outlet Plug for the DC House Project}

A wall outlet plug for the DC house was initially designed during phase 1 [8]. The wall outlet plug was based on a Flyback DC-DC converter design that had a maximum output power of $80 \mathrm{~W}$. The DC-DC converter allowed fixed output voltages of $5 \mathrm{~V}, 12 \mathrm{~V}, 19 \mathrm{~V}$, and $24 \mathrm{~V}$ for the different appliances. In order to change the output voltage for a certain appliance, the user must manually choose a selector pin $\left(\mathrm{R}_{\text {SELECT }}\right)$ inside the plug receptacle that indicates a certain voltage shown in Figure 2-5. This implies that the user must have the knowledge of which voltage to select prior to connecting the load to the wall plug. A push for an improved wall outlet plug was therefore necessary due to the concerns for a user choosing the wrong output voltage which in turn may damage the load or appliance. This thesis proposes a new method for a DC wall plug. Rather than relying on user's knowledge for different setting of a DC load, the proposed wall plug will employ an automatic voltage sensing scheme. This way the user may safely connect any DC load without damaging the DC load/device connected to the DC wall plug due to the wrong selection of voltage setting.

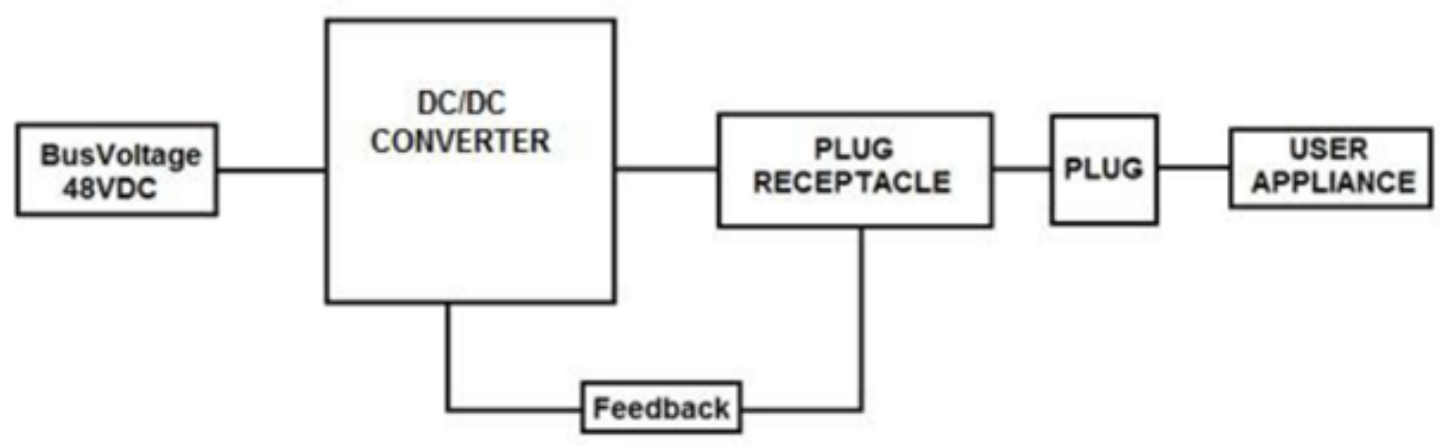

Figure 2-4: Phase 1 DC Wall Plug System Block Diagram [8] 


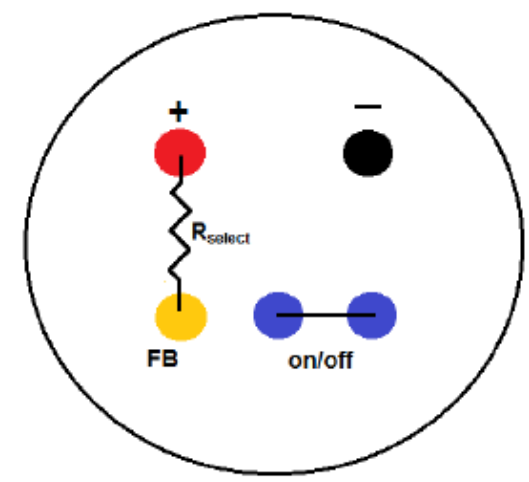

Figure 2-5: Phase 1 Plug Design [8] 


\section{CHAPTER 3: DESIGN CONSTRAINTS \& REQUIREMENTS}

This chapter will explain the desired overall functionality of the proposed smart dc wall plug along with the steps taken to determine its design constraints and requirements. Component selection to construct the proposed wall plug will be detailed and characterization of three dc loads used for testing will also be presented.

\section{1 - Overall Design Requirements}

The DC House wall plug must employ a buck converter because it has to step down from 48 Volts at the main DC bus of the DC House to a range of lower load voltages required by various appliances. These load voltages would depend on voltage rating of the appliances used in the DC House. One important assumption which will be the fundamental basis of how the proposed smart plug operates is that each appliance connected to the wall plug start to turn on when the appliance minimum voltage rating is met and as a result, current exists and flows into the appliance. Therefore, the proposed wall plug will implement a current monitor supplied from its output, hence from the buck converter, which in turn will determine when the appliance is on at a certain output voltage. The output voltage is being adjusted using a simple voltage divider network feeding back from the output terminal of the buck converter to the controller chip. Therefore, there is the need to be able to modify the voltage divider network automatically as the current monitor is sensing different level of output currents. This is where a microcontroller that interfaces to a digital potentiometer will be useful. Per given output current sensed by the converter, the digital potentiometer determines the appropriate output voltage to respond and provides two options: the digital potentiometer either ramps up the output voltage to turn on the 
appliance or stays at a constant voltage once the voltage rating has been met. The system block diagram is shown in Figure 3-1.

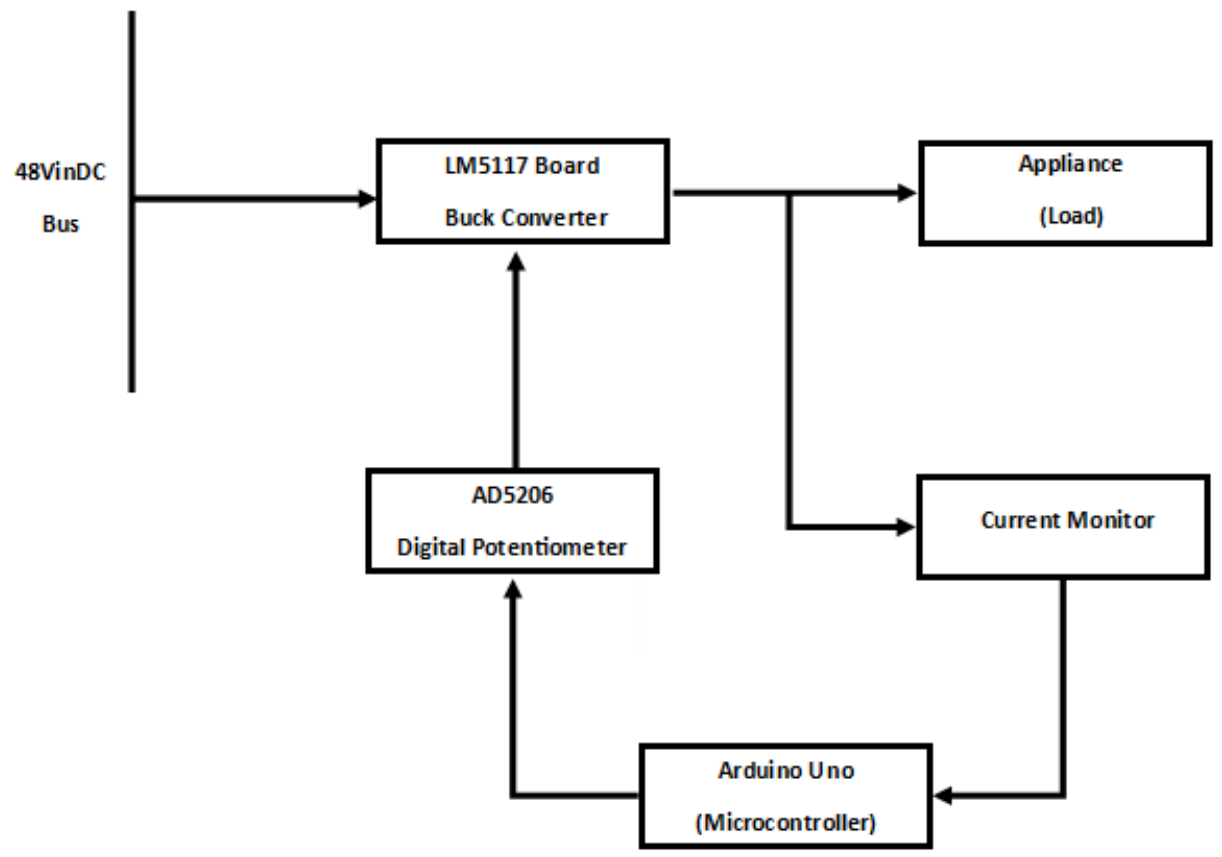

Figure 3-1: Block Diagram for the Wall Outlet

\section{2 - Output Voltages Constraints}

In order to determine the range of output voltages for the buck converter, data were gathered from different dc appliances. The appliances include cell phone chargers, tablet chargers, radios, fans, DC TVs, DC refrigerators, and laptop chargers. According to Tables 3-2 and 3-8, appliance input ratings spanned from $5 \mathrm{~V}$ to $24 \mathrm{~V}$, and hence this constitute the ideal range of the output voltage produced by the buck converter. Previous study as reported in [8] also suggests that common voltage ratings for dc appliances are $5 \mathrm{~V}, 12 \mathrm{~V}, 19 \mathrm{~V}, \& 24 \mathrm{~V}$. 


\section{3 - Output Power Constraints}

Not only were the output voltages determined, but the output power for each appliance was recorded as well. This step is necessary to determine the maximum output power rating of the proposed dc wall plug. Furthermore, each buck converter used in the wall plug may only have one single load can be connected. In other words, each individual wall plug cannot be branched out to supply two or more different dc loads. Based on the data listed from Tables 3-2 to $3-8$, it was decided that the maximum output power should be $135 \mathrm{~W}$. However, since the DC house allows $600 \mathrm{~W}$ of DC generation, a $100 \mathrm{~W}$ is finally selected for the wall plug with the assumption that most dc loads will fall below this range, and for those loads requiring higher power a bigger rated dc plug will have to be purchased and installed. This way, the cost of overall electrical distribution system inside the DC House may be minimized. Once the output power is determined in Equation 3-1, the output current can then be calculated in Equation 3-2:

$$
\text { Power }[W]=\text { Current }[I] * \text { Voltage }[V]
$$

\section{Equation 3-1: Power Calculation to Determine Output Power}

$$
\text { Current }[A]=\frac{\text { Power }[W]}{\text { Voltage }[V]}
$$

\section{Equation 3-2: Current Calculation to Determine Output Current}


Table 3-1: Initial Design for Output Voltage \& Power Ratings

\begin{tabular}{|c|c|c|c|}
\hline $\begin{array}{c}\text { Vout } \\
(\mathbf{V})\end{array}$ & $\begin{array}{c}\text { Vin } \\
(\mathbf{V})\end{array}$ & $\begin{array}{c}\text { Pout } \\
(\mathbf{W})\end{array}$ & $\begin{array}{c}\text { Iout } \\
(\mathbf{A})\end{array}$ \\
\hline 5 & 48 & 100 & 20.00 \\
\hline 6 & 48 & 100 & 16.67 \\
\hline 7 & 48 & 100 & 14.29 \\
\hline 8 & 48 & 100 & 12.50 \\
\hline 9 & 48 & 100 & 11.11 \\
\hline 10 & 48 & 100 & 10.00 \\
\hline 11 & 48 & 100 & 9.09 \\
\hline 12 & 48 & 100 & 8.33 \\
\hline 13 & 48 & 100 & 7.69 \\
\hline 14 & 48 & 100 & 7.14 \\
\hline 15 & 48 & 100 & 6.67 \\
\hline 16 & 48 & 100 & 6.25 \\
\hline 17 & 48 & 100 & 5.88 \\
\hline 18 & 48 & 100 & 5.56 \\
\hline 19 & 48 & 100 & 5.26 \\
\hline 20 & 48 & 100 & 5.00 \\
\hline 21 & 48 & 100 & 4.76 \\
\hline 22 & 48 & 100 & 4.55 \\
\hline 23 & 48 & 100 & 4.35 \\
\hline 24 & 48 & 100 & 4.17 \\
\hline
\end{tabular}

Table 3-2: Cell Phone Charger Voltage \& Power Ratings

\begin{tabular}{|c|c|c|c|c|}
\hline Cell Phone Charger & Vmin (V) & Vtyp (V) & Vmax (V) & Pmax (W) \\
\hline RG-TC-056-Nokia6101 & 4.8 & 5 & 5.2 & 3.12 \\
\hline RG-TC-056-micro USB & 4.8 & 5 & 5.2 & 3.12 \\
\hline RG-TC-056-Sony-Ericsson K750 & 4.8 & 5 & 5.2 & 3.12 \\
\hline RG-TC-056-Samsung D800 & 4.8 & 5 & 5.2 & 3.12 \\
\hline Apple iPhone USB Charger & 4.75 & 5 & 5.25 & 5 \\
\hline
\end{tabular}

Table 3-3: Tablet Voltage \& Power Ratings

\begin{tabular}{|c|c|c|c|c|}
\hline Tablets & Vmin (V) & Vtyp (V) & Vmax (V) & Pmax (W) \\
\hline Barnes \& Noble Nook Tablet & 4.5 & 5 & 5.5 & 4.25 \\
\hline iPad 2 & 4.75 & 5 & 5.25 & 10 \\
\hline Samsung Galaxy Tab 10.1 & 4.5 & 5 & 5.5 & 10 \\
\hline Asus Eee Pad Transformer (TF101) & 13.5 & 15 & 16.5 & 18 \\
\hline Sony Tablet S & 9.45 & 10.5 & 11.55 & 30.45 \\
\hline
\end{tabular}


Table 3-4: Radio Voltage \& Power Ratings

\begin{tabular}{|c|c|c|c|c|}
\hline Radio & Vmin $(\mathbf{V})$ & $\begin{array}{c}\text { Vtyp } \\
(\mathbf{V})\end{array}$ & $\begin{array}{c}\text { Vmax } \\
(\mathbf{V})\end{array}$ & $\begin{array}{c}\text { Pmax } \\
(\mathbf{W})\end{array}$ \\
\hline Sony ICF38 Portable AM/FM Radio (Black) & 5.4 & 6 & 6.6 & 0.4 \\
\hline $\begin{array}{c}\text { Sangean Multi-Powered AM/FM Radio MMR- } \\
\mathbf{7 7}\end{array}$ & 2.7 & 3 & 3.3 & 0.6 \\
\hline $\begin{array}{c}\text { Sangean FM-Stereo RBDS/AM Digital Tuning } \\
\text { Portable Stereo Radio (Black) PR-D5 }\end{array}$ & 8.1 & 9 & 9.9 & 4.5 \\
\hline $\begin{array}{c}\text { Solar Radio with 12V DC Input Jack and } \\
\text { Emergency Flashlight }\end{array}$ & 10.8 & 12 & 13.2 & 4.8 \\
\hline $\begin{array}{c}\text { Aker Voice Amplifier \& Mp3 Player \& FM } \\
\text { Radio 16watts Black MR2800 }\end{array}$ & 6.75 & 7.5 & 8.25 & 16 \\
\hline
\end{tabular}

Table 3-5: DC Fan Voltage \& Power Ratings

\begin{tabular}{|c|c|c|c|c|}
\hline DC Fan & Vmin (V) & $\begin{array}{c}\text { Vtyp } \\
(\mathbf{V})\end{array}$ & $\begin{array}{c}\text { Vmax } \\
(\mathbf{V})\end{array}$ & $\begin{array}{c}\text { Pmax } \\
(\mathbf{W})\end{array}$ \\
\hline 12 / 24 Volt 60" 3-Blade Ceiling Fan & & 12 & & 6 \\
\hline $\begin{array}{c}\text { 10' 12 Volt or Battery Power Portable Fan } \\
\text { (Provided by Mark Cabaj) }\end{array}$ & & 12 & & 6 \\
\hline 12 or 24 Volt 42" Ceiling Fan w/Remote Control & & 12 & & 14.4 \\
\hline 12 Volt Fans from Endless Breeze & & 12 & & 36 \\
\hline Freedom Fan Model 302 & & 12 & & 48 \\
\hline
\end{tabular}

Table 3-6: DC TV Voltage \& Power Ratings

\begin{tabular}{|c|c|c|c|c|}
\hline DC TV & $\begin{array}{c}\text { Vmin } \\
\text { (V) }\end{array}$ & $\begin{array}{c}\text { Vtyp } \\
\text { (V) }\end{array}$ & $\begin{array}{c}\text { Vmax } \\
(\mathrm{V})\end{array}$ & $\begin{array}{c}\text { Pmax } \\
(\mathrm{W})\end{array}$ \\
\hline 12-Volt TV and 12 Volt TV DVD & & 12 & & 24 \\
\hline $\begin{array}{c}\text { 13.3" NAXA AC/DC Digital Flat Screen HD } \\
\text { Television with DVD }\end{array}$ & & 12 & & 36 \\
\hline $\begin{array}{c}\text { 22" (21.6") Skyworth LED 12 Volt TV DVD Combo } \\
\text { Digital Tuner SLC2219A }\end{array}$ & & 12 & & 42 \\
\hline $\begin{array}{c}12 \text { Volt TV/DVD 15" AudioVox AC/DC Flat Screen } \\
\text { TV DVD }\end{array}$ & & 12 & & 50 \\
\hline 13" Memorex 12-Volt TV DVD CD MP3 Player & & 12 & & 70 \\
\hline 32" 12Volt Television LED w/HiDef by Jensen & & 12 & & 90 \\
\hline
\end{tabular}


Table 3-7: DC Refrigerators Voltage \& Power Ratings

\begin{tabular}{|c|c|c|c|c|}
\hline DC Refrigerators & $\begin{array}{c}\text { Vmin } \\
(\mathbf{V})\end{array}$ & $\begin{array}{c}\text { Vtyp } \\
(\mathbf{V})\end{array}$ & $\begin{array}{c}\text { Vmax } \\
(\mathbf{V})\end{array}$ & $\begin{array}{c}\text { Pmax } \\
(\mathbf{W})\end{array}$ \\
\hline SunDanzer & 10.4 & 12 & 17 & 80 \\
\hline EdgeStar 80 (FP861) @ (-13.3\%) & 10.4 & 12 & 12.6 & 80 \\
\hline Engel MT17 & & 12 & & 27.6 \\
\hline EdgeStar 43 (FP430) @ (+13.3\%/-13.3\%) & 10.4 & 12 & 12.6 & 65 \\
\hline Fridge -Freezers MRFD-015D & & 12 & & 46.8 \\
\hline $\begin{array}{c}\text { 12V Snackmaster Deluxe Family Size } \\
\text { Cooler/Warmer }\end{array}$ & 12 & & 50.4 \\
\hline
\end{tabular}

Table 3-8: Laptop Charger Voltage \& Power Ratings

\begin{tabular}{|c|c|c|c|c|}
\hline Laptop Chargers & $\begin{array}{c}\text { Vmin } \\
(\mathbf{V})\end{array}$ & Vtyp (V) & $\begin{array}{c}\text { Vmax } \\
(\mathbf{V})\end{array}$ & Pmax (W) \\
\hline Toshiba 45Watt Global AC Adapter & & 15 & & 45 \\
\hline Acer Aspire 1640 AC Adapter & & 19 & & 65 \\
\hline Toshiba 65-Watt Glocal AC Adapter & & 19 & & 65 \\
\hline DELL 5U092 PA-12 65 Watt AC Adapter & & 19.5 & & 65 \\
\hline Toshiba 75-Watt Global AC Adapter & & 19 & & 75 \\
\hline Dell Inspiron 2600 AC Adapter & & 20 & & 90 \\
\hline Sony PCGA-AC19V 120W AC Adapter & & 19.5 & & 120 \\
\hline DELL D1078 PA-13 130 Watt AC Adapter & & 19.5 & & 130 \\
\hline HP Compaq Pavilion ZX5100 AC Adapter & & 19 & & \\
135W & & & 135 \\
\hline
\end{tabular}

The minimum, typical, and maximum voltage ratings for each appliance are tabulated and plotted so that the variation in output voltages can be observed easily which helps in determining the output voltage range of the proposed dc wall plug. 
Table 3-9: Vmax, Vmin, Vtyp ratings for each appliance

\begin{tabular}{|c|c|c|c|}
\hline $\begin{array}{c}\text { Appliance } \\
\text { Cell Phone Chargers }\end{array}$ & $\begin{array}{c}\text { Vmax } \\
(\mathbf{V})\end{array}$ & $\begin{array}{c}\text { Vmin } \\
(\mathbf{V})\end{array}$ & $\begin{array}{c}\text { Vtyp } \\
(\mathbf{V})\end{array}$ \\
\hline Tablet Chargers & 16.5 & 4.75 & 5 \\
\hline Radios & 13.2 & 2.5 & 5 \\
\hline Fans & & & 3 \\
\hline TVs & & & 12 \\
\hline Refrigerators & 17 & 10.4 & 12 \\
\hline Laptop Chargers & & & 19 \\
\hline
\end{tabular}




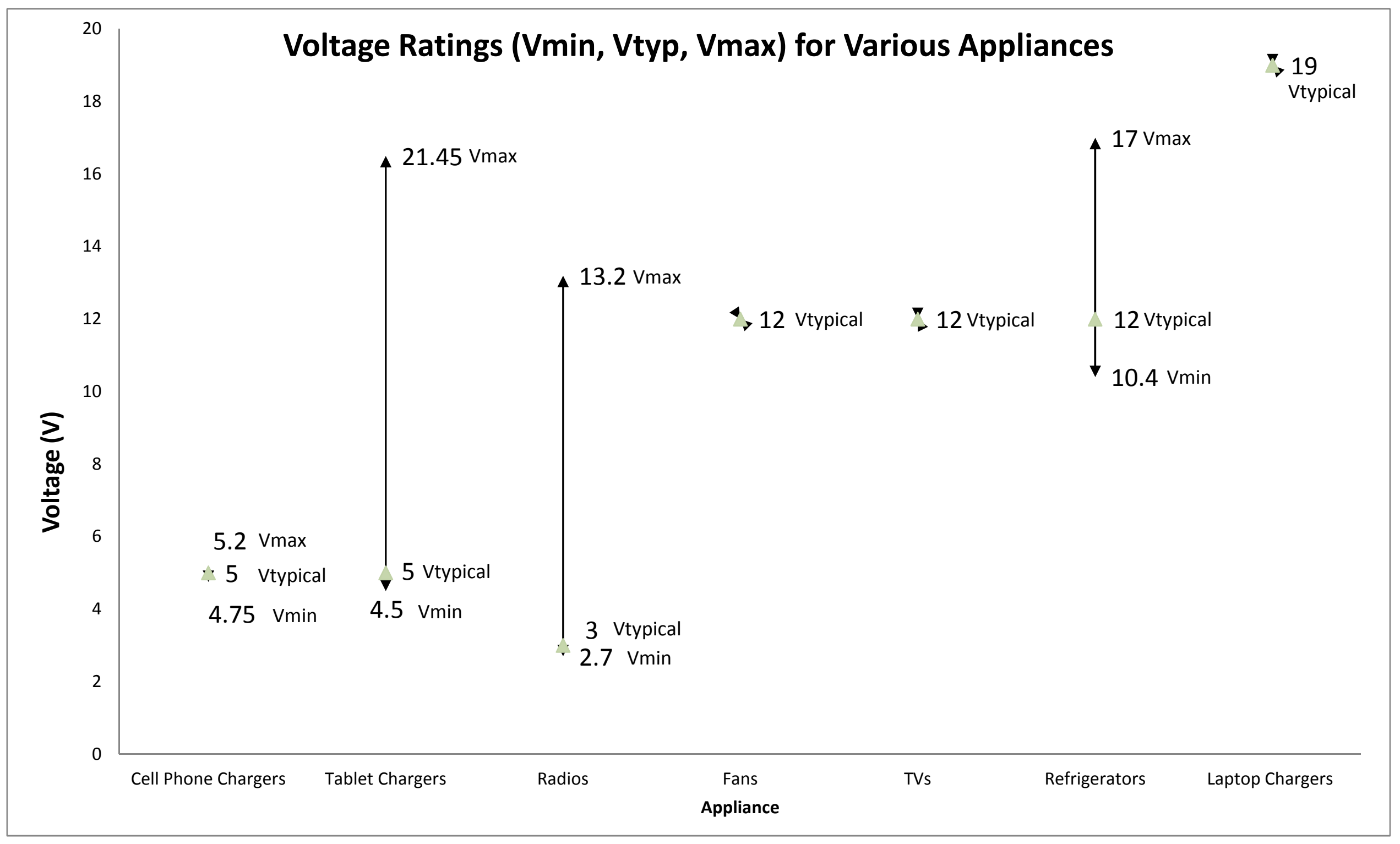

Figure 3-2: Graphical Representation for Different Input Voltage Ratings (Vmin, Vtyp, Vmax) for Various Appliances 


\section{3 - Buck Converter Selection}

As previously mentioned, the main DC bus of the DC House is $48 \mathrm{~V}$ while the loads are typically at some lower voltages. This calls for the step down converter also known as the Buck converter. Design requirements for the Buck converter are based on the data shown in Table 3-1. For the proposed smart dc wall plug, since the focus in on automatic adjustment method and algorithm, therefore the Buck converter will be selected from a commercially available buck converter or module instead of designing own converter. After researching through off-the-shelf converters and available evaluation board modules, LM5117 Buck converter evaluation board from Texas Instruments was selected due to its ability to accept a high input voltage needed for the DC House project; i.e. it has a wide operating range input voltage from $5.5 \mathrm{~V}$ to $65 \mathrm{~V}$ as shown in Figure 3-3. Most importantly, however, is that the converter provides an analog output current monitor as shown in Figure 3-4. This is particularly very useful for sensing current at the output of the converter as the assumption is that a dc load will start drawing current as its voltage is nearing its nominal value. 


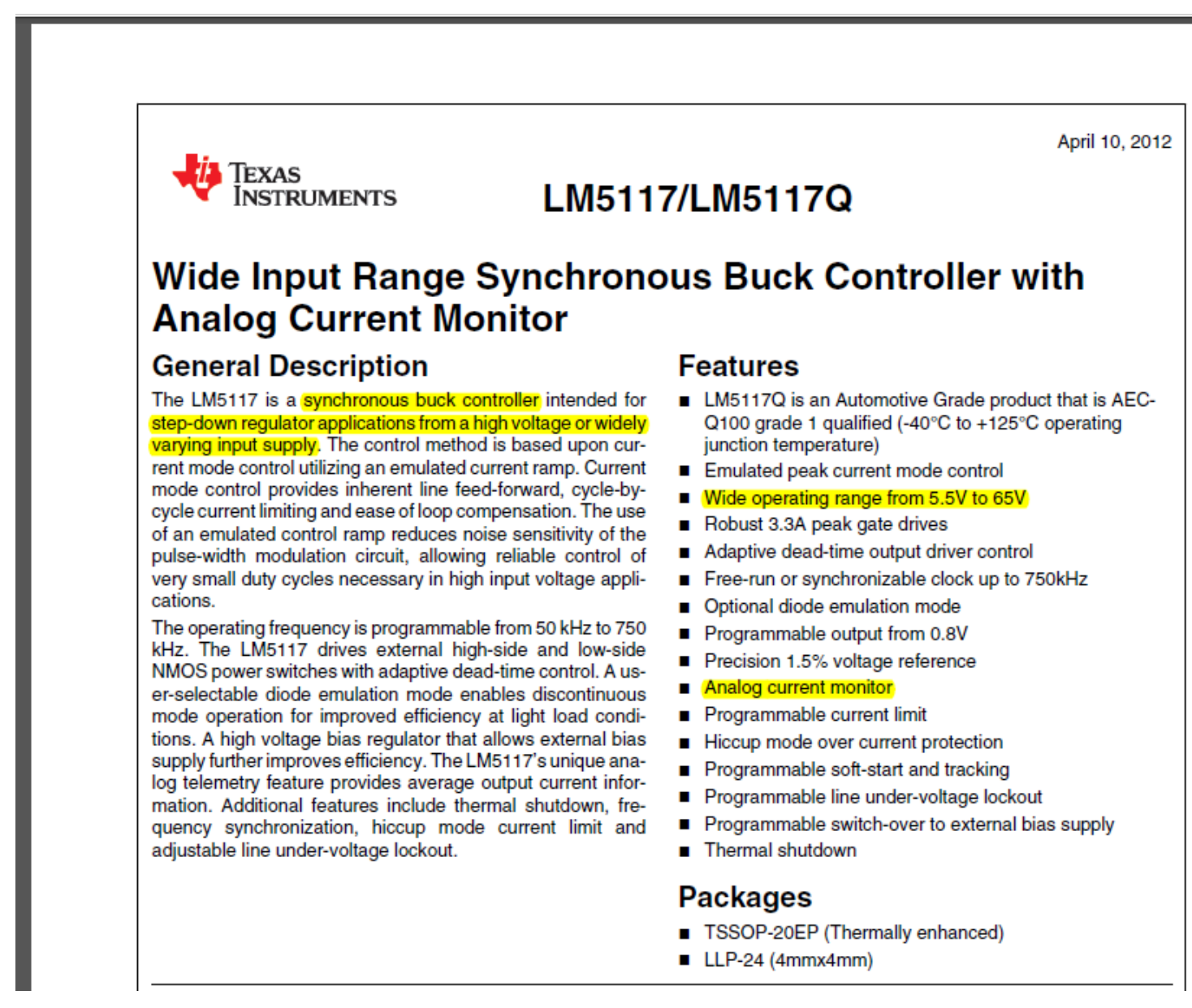

Figure 3-3: LM5117 Datasheet [22]

\section{Current Monitor}

The LM5117 provides average output current information, enabling various applications requiring monitoring or control of the output current.

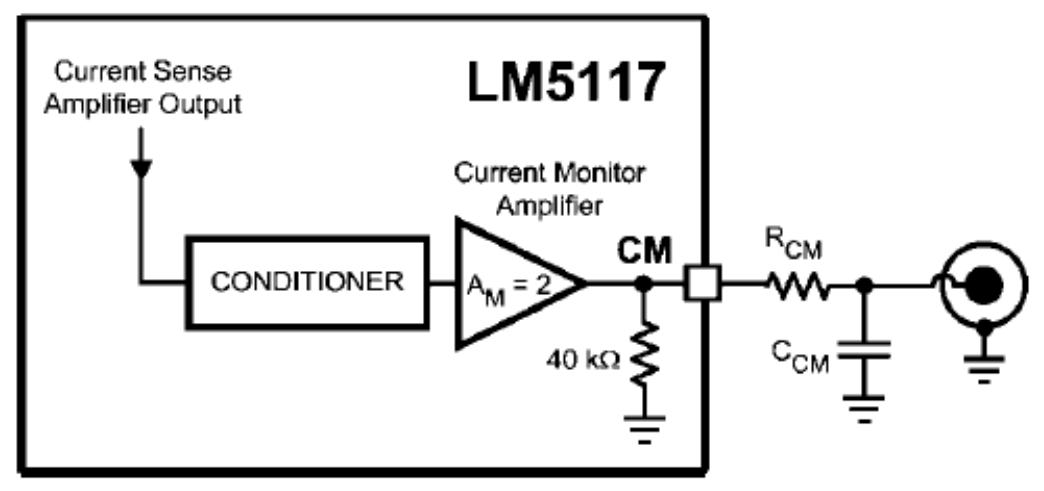

Figure 3-4: The LM5117 Current Monitor [22] 
The current monitor provides average output current information translated into voltage. This voltage will then be fed into a microcontroller which only accepts analog voltages. Also, the same current monitor output is only valid when the inductor is operating in continuous conduction mode. The average voltage of the current monitor can be calculated in Equation 3-3:

$$
V c m_{\text {ave }}=\left(I_{\text {outDC }}\right) \times R_{s} \times A_{M} \times A_{s}[\mathrm{~V}]
$$

\section{Equation 3-3: Average Voltage Calculation from the Current Monitor}

$$
\begin{aligned}
& \text { Where, } \mathrm{V}_{\mathrm{CM}_{-} \text {Ave }}=\text { Average voltage of the current monitor } \\
& \mathrm{I}_{\mathrm{OUTDC}}=\text { Average output current } \\
& \mathrm{R}_{\mathrm{s}}=\text { Sense Resistor }=0.008 \Omega \\
& \mathrm{A}_{\mathrm{M}}=\text { Current Monitor Amplifier Gain } \\
& \mathrm{A}_{\mathrm{s}}=\text { Current Sense Amplifier Gain }
\end{aligned}
$$

\section{4 - Output Voltage Constraints}

As mentioned, the buck converter is an evaluation board that has design limits for its output voltage and output current shown in Figure 3-5. According to the evaluation board specifications, the output current is rated at 9 Amps and the output voltage is rated at 12 Volts. This limits the converter to output fewer amps than it was initially designed because of the designed rated output power. For example, rated output voltage at $5 \mathrm{~V}$ and rated output power at $100 \mathrm{~W}$ would result in $20 \mathrm{~A}$ rated output current. The 20 A exceeds the 9 A specification which may in turn damage the converter. 


\section{Performance of the Evaluation}

Board

- Input Voltage Range: $15 \mathrm{~V}$ to $55 \mathrm{~V}$

- Output Voltage: 12V

- Output Current: 9A

- Nominal Switching Frequency: 230 kHz

- Synchronous Buck Operation: Yes

- Diode Emulation Mode: Yes

- Hiccup Mode Overload Protection: Yes

- External VCC Sourcing: Yes

- Current Monitor Output: Yes

\section{Figure 3-5: LM5117 Evaluation Board [23]}

Because of this limitation and to avoid any damage to the converter, the designed output power is decreased to $50 \mathrm{~W}$ and the new chosen output voltages are from $5 \mathrm{~V}$ to $15 \mathrm{~V}$. These voltages are designed for appliances such as the cell phone charger, tablet charger, radio, DC fan, DC TV, and DC refrigerators. Choosing the average of the output voltages is more appropriate for this design because it gives more flexibility in testing different appliances. A new design table is constructed, see Table 3-10. The red block denotes that the current or voltage exceeds the evaluation board's specifications. The green block denotes that the current or voltage meets within the specifications. However, both current and voltage must meet within the specifications, which are also denoted by the orange block. Therefore, the new design requirements for the chosen output voltages are $5 \mathrm{~V}-15 \mathrm{~V}$ shown in Table 3-11. 
Table 3-10: DC Wall Outlet Possible Design Requirements Layout

\begin{tabular}{|c|c|c|c|}
\hline $\begin{array}{c}\text { Vin } \\
(\mathbf{V})\end{array}$ & $\begin{array}{c}\text { Vout } \\
(\mathbf{V})\end{array}$ & $\begin{array}{c}\text { Iout } \\
(\mathbf{A})\end{array}$ & Pout $(\mathbf{W})$ \\
\hline 48 & 5 & 10 & 50 \\
\hline 48 & 6 & 8.33 & 50 \\
\hline 48 & 7 & 7.14 & 50 \\
\hline 48 & 8 & 6.25 & 50 \\
\hline 48 & 9 & 5.55 & 50 \\
\hline 48 & 10 & 5 & 50 \\
\hline 48 & 11 & 4.54 & 50 \\
\hline 48 & 12 & 4.16 & 50 \\
\hline 48 & 13 & 3.84 & 50 \\
\hline 48 & 14 & 3.57 & 50 \\
\hline 48 & 15 & 3.33 & 50 \\
\hline 48 & 16 & 3.12 & 50 \\
\hline 48 & 17 & 2.94 & 50 \\
\hline 48 & 18 & 2.77 & 50 \\
\hline 48 & 19 & 2.63 & 50 \\
\hline 48 & 20 & 2.5 & 50 \\
\hline 48 & 21 & 2.38 & 50 \\
\hline 48 & 22 & 2.27 & 50 \\
\hline 48 & 23 & 2.17 & 50 \\
\hline 48 & 24 & 2.08 & 50 \\
\hline
\end{tabular}

Table 3-11: Final Design Requirements for the DC Wall Outlet

\begin{tabular}{|c|c|c|c|}
\hline $\begin{array}{c}\text { Vin } \\
(\mathbf{V})\end{array}$ & Vout (V) & $\begin{array}{c}\text { Iout } \\
(\mathbf{A})\end{array}$ & Pout (W) \\
\hline 48 & 5 & 10 & 50 \\
\hline 48 & 6 & 8.33 & 50 \\
\hline 48 & 7 & 7.14 & 50 \\
\hline 48 & 8 & 6.25 & 50 \\
\hline 48 & 9 & 5.55 & 50 \\
\hline 48 & 10 & 5 & 50 \\
\hline 48 & 11 & 4.54 & 50 \\
\hline 48 & 12 & 4.16 & 50 \\
\hline 48 & 13 & 3.8462 & 50 \\
\hline 48 & 14 & 3.5714 & 50 \\
\hline 48 & 15 & 3.3333 & 50 \\
\hline
\end{tabular}




\section{5 - Microcontroller Selection: The Arduino Uno}

The Arduino Uno shown in Figure 3-6 is chosen as the microcontroller because it provides features necessary for simple, proper functionality for the converter to interface with the digital potentiometer and ultimately change the output voltages.

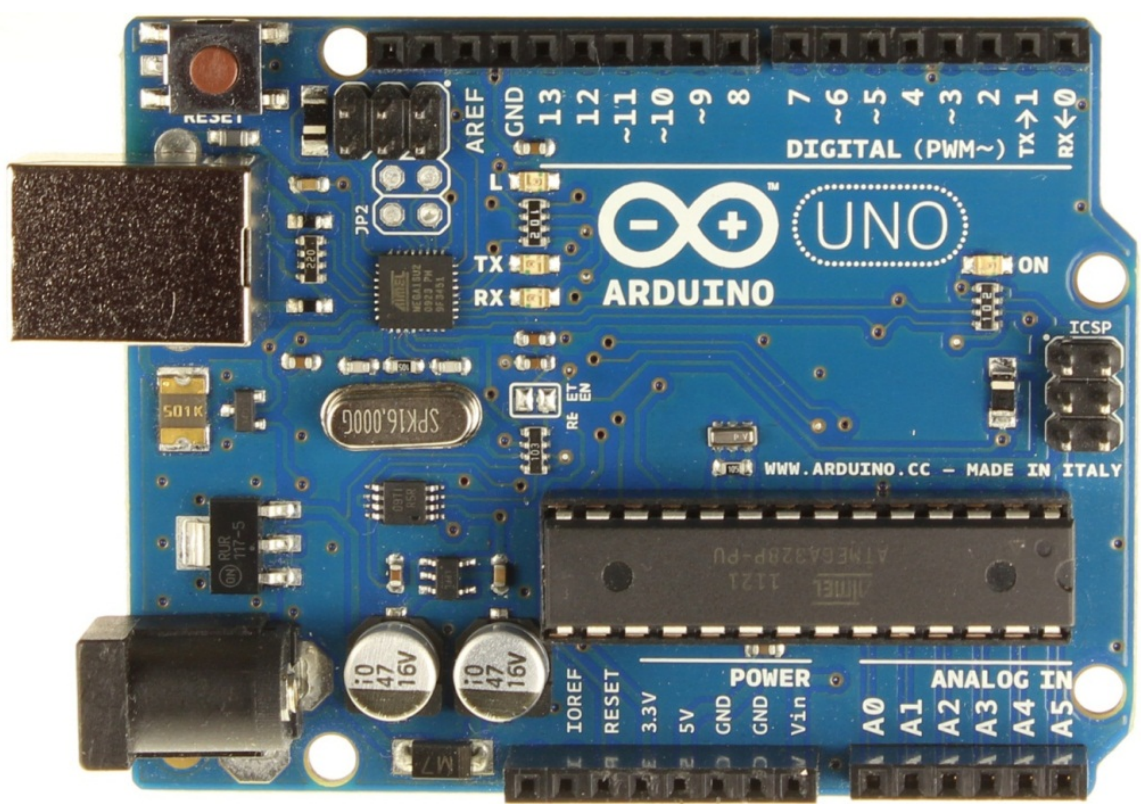

Figure 3-6: The Arduino Uno Microcontroller [24]

The Arduino Uno provides a Serial Peripheral Interface (SPI) Bus, so that data are made possible to communicate with external components such as the digital potentiometer. Moreover, the Arduino Uno utilizes a $<$ SPI.h $>$ library to initialize any connections from its board interface specifically to the digital potentiometer.

The Arduino Uno microcontroller is based on the programming languages $\mathrm{C} / \mathrm{C}++. \mathrm{C}++$ allows the programmer to link to microcontroller libraries (e.g. AVR Libc) in order to use any of 
its functions, rather than writing certain functions by scratch. For this project, calling the functions will make SPI initialization easier and faster.

Another feature that the Arduino Uno has is its Analog-to-Digital (ADC) converter. The microcontroller takes in analog voltage inputs and converts them to digital signals. This is done by the analogRead() function shown in the description below in Figure 3-7 [25]. These digital signals are then used to interface with the code to perform the converter's function to output different voltages. The analogRead() function is important because it is used to read the current sense information from the current monitor. The microcontroller takes the current information and will increase the output voltage until it sees current present at the output.

\section{$\operatorname{analogRead}()$}

\section{Description}

Reads the value from the specified analog pin. The Arduino board contains a 6 channel ( 8 channels on the Mini and Nano, 16 on the Mega), 10-bit analog to digital converter. This means that it will map input voltages between 0 and 5 volts into integer values between 0 and 1023 . This yields a resolution between readings of: 5 volts / 1024 units or, .0049 volts ( $4.9 \mathrm{mV}$ ) per unit. The input range and resolution can be changed using analogReference().

It takes about 100 microseconds $(0.0001 \mathrm{~s})$ to read an analog input, so the maximum reading rate is about 10,000 times a second.

\section{Syntax}

analogRead(pin)

\section{Parameters}

pin: the number of the analog input pin to read from ( 0 to 5 on most boards, 0 to 7 on the Mini and Nano, 0 to 15 on the Mega)

\section{Returns}

int (0 to 1023)

\section{Figure 3-7: Arduino Uno Specifications for AnalogRead() function [25]}




\section{6 - Digital Potentiometer Selection: AD5206}

Another crucial component in the proposed smart dc plug design is the digital potentiometer. This potentiometer as explained later will be utilized to adjust the feedback resistor into the buck converter. This should effectively adjust the output voltage. The AD5206 was selected as the digital potentiometer. The AD5206 chips are available in different resistor values: $10 \mathrm{k} \Omega, 50 \mathrm{k} \Omega$, and $100 \mathrm{k} \Omega$. The various resistor values of the digital potentiometer are represented as digital values from 0 to 255 [26] so that the Arduino is able to interface with the analog information. In this case, the $10 \mathrm{k} \Omega$ resistor value was chosen so that it meets the required resistor (R2) values from $281 \Omega$ to $953 \Omega$. Although the digital potentiometer is not able to exactly match the required resistance value, the lowest available resistance gives more availability to lower values.

The physical connections for the digital potentiometer are similar to an analog potentiometer. Both potentiometers have the A terminal, Wiper pin, and a B terminal. In order to utilize the variable resistance, one connection must be connected to either the A terminal or the B terminal. The second connection must be connected to the wiper. For convenience, the B to W connection is used since increasing the digital resistance values (from 0 to 255) is equivalent to increasing the analog resistance $(0 \Omega$ to $10 \mathrm{k} \Omega)$ shown in Table 3-12. If the programmer decides to use the A to $\mathrm{W}$ connection, increasing the digital resistance values (from 0 to 255) would mean decreasing the analog resistance $(10 \mathrm{k} \Omega$ to $0 \Omega)$ shown in Table $3-13$. 
Table 3-12: Output Resistance Values when $V_{B}=0 \mathrm{~V}$ and Terminal $A=$ Open Circuited [26]

\begin{tabular}{l|l|l}
\hline $\mathbf{D}($ Dec $)$ & RwB $(\Omega)$ & Output State \\
\hline 255 & 10006 & Full scale \\
128 & 5045 & Midscale $(\overline{\mathrm{PR}}=0$ condition) \\
1 & 84 & 1 LSB \\
0 & 45 & Zero scale (wiper contact resistance) \\
\hline
\end{tabular}

Table 3-13: Output Resistance Values when $V_{A}=0 \mathrm{~V}$ and Terminal $B=$ Tied to Wiper $W$ [26]

\begin{tabular}{l|l|l}
\hline D (DEC) & Rwa $(\Omega)$ & Output State \\
\hline 255 & 84 & Full scale \\
128 & 5045 & Midscale $(\overline{\mathrm{PR}}=0$ condition) \\
1 & 10006 & 1 LSB \\
0 & 10045 & Zero scale \\
\hline
\end{tabular}

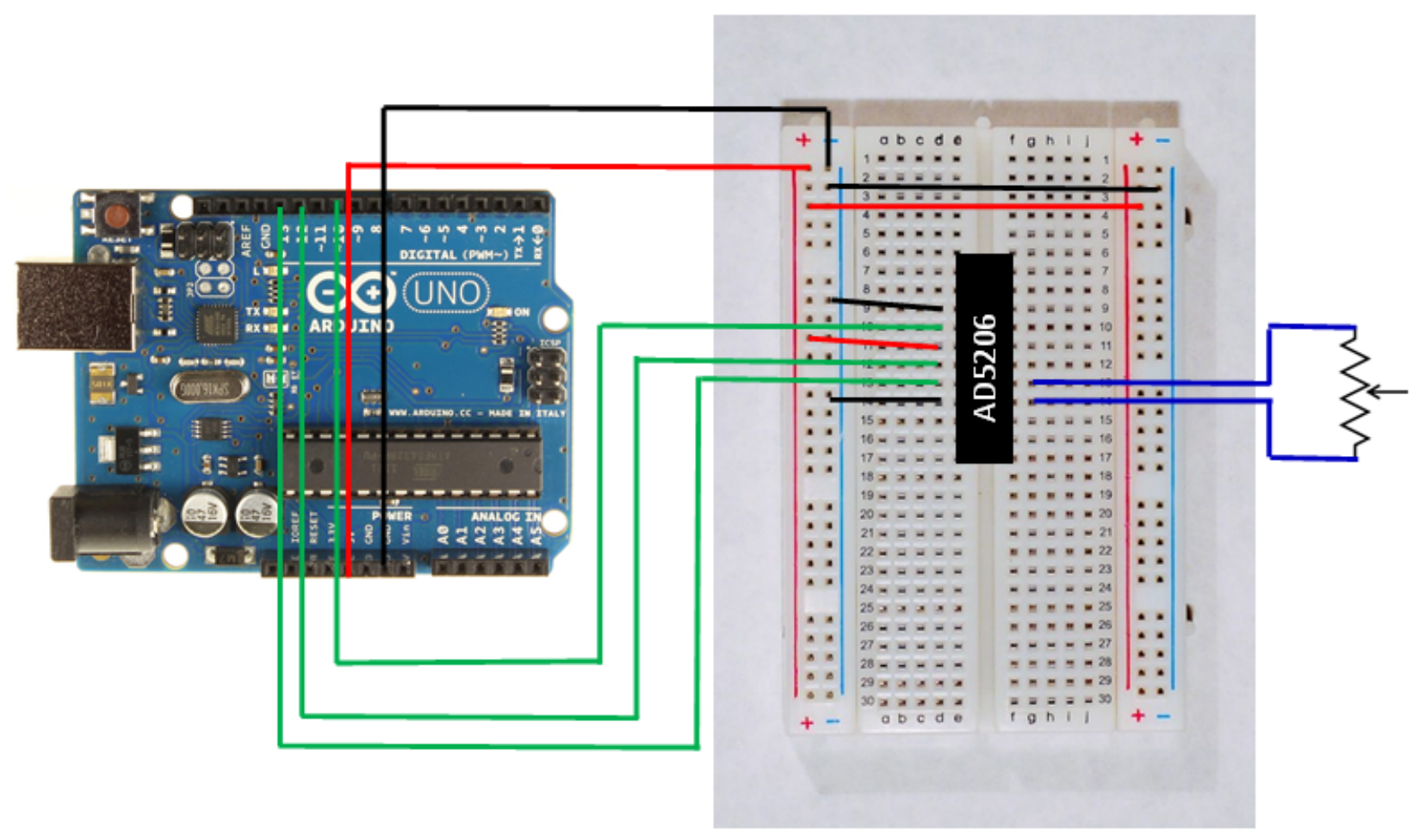

Figure 3-8: Arduino Hardware Connections to the Digital Potentiometer (AD5206) 
The AD5206 pins and the descriptions of the pins are shown below in Figures 3-9 and 310. The AD5206 offers six digital potentiometers in one chip, but in this implementation only one digital potentiometer (i.e. A1, W1, B1) is used. All connections from the Arduino board to the AD5206 chip, AD5206 chip to the breadboard, and to the LM5117 evaluation board are shown in Table 4-14 to Table 4-16.

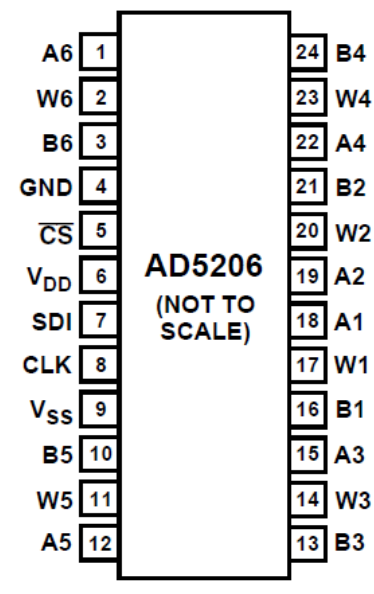

Figure 3-9: AD5206 Pin Configuration [26] 


\begin{tabular}{|c|c|c|}
\hline $\begin{array}{l}\text { Pin } \\
\text { No. }\end{array}$ & Name & Description \\
\hline 1 & A6 & A Terminal RDAC \#6. \\
\hline 2 & W6 & Wiper RDAC \#6, addr $=101_{2}$. \\
\hline 3 & B6 & B Terminal RDAC \#6. \\
\hline 4 & GND & Ground. \\
\hline 5 & $\overline{\mathrm{CS}}$ & $\begin{array}{l}\text { Chip Select Input, Active Low. When } \overline{\mathrm{CS}} \\
\text { returns high, data in the serial input register } \\
\text { is decoded based on the address bits and } \\
\text { loaded into the target RDAC latch. }\end{array}$ \\
\hline 6 & $\mathrm{~V}_{\mathrm{DD}}$ & $\begin{array}{l}\text { Positive power supply, specified for } \\
\text { operation at both }+3 \mathrm{~V} \text { or }+5 \mathrm{~V} \text {. (Sum of } \\
\left|\mathrm{V}_{\mathrm{DD}}\right|+\left|\mathrm{V}_{\mathrm{SS}}\right|<5.5 \mathrm{~V} \text {.) }\end{array}$ \\
\hline 7 & SDI & Serial Data Input. MSB First. \\
\hline 8 & CLK & Serial Clock Input, positive edge triggered. \\
\hline 9 & $\mathrm{~V}_{\mathrm{SS}}$ & $\begin{array}{l}\text { Negative Power Supply, specified for } \\
\text { operation at both } 0 \mathrm{~V} \text { or }-2.7 \mathrm{~V} \text {. (Sum of } \\
\left|\mathrm{V}_{\mathrm{DD}}\right|+\left|\mathrm{V}_{\mathrm{SS}}\right|<5.5 \mathrm{~V} \text {.) }\end{array}$ \\
\hline 10 & B5 & B Terminal RDAC \#5. \\
\hline 11 & W5 & Wiper RDAC \#5, addr $=100_{2}$. \\
\hline 12 & A5 & A Terminal RDAC \#5. \\
\hline 13 & B3 & B Terminal RDAC \#3. \\
\hline 14 & W3 & Wiper RDAC \#3, addr $=010_{2}$. \\
\hline 15 & A3 & A Terminal RDAC \#3. \\
\hline 16 & B1 & B Terminal RDAC \#1. \\
\hline 17 & W1 & Wiper RDAC \#1, addr $=000_{2}$. \\
\hline 18 & A1 & A Terminal RDAC \#1. \\
\hline 19 & $\mathrm{~A} 2$ & A Terminal RDAC \#2. \\
\hline 20 & W2 & Wiper RDAC \#2, addr $=001_{2}$. \\
\hline 21 & B2 & B Terminal RDAC \#2. \\
\hline 22 & $\mathrm{~A} 4$ & A Terminal RDAC \#4. \\
\hline 23 & W4 & Wiper RDAC \#4, addr $=011_{2}$. \\
\hline 24 & B4 & B Terminal RDAC \#4. \\
\hline
\end{tabular}

Figure 3-10: AD5206 Pin Function Descriptions [26]

Table 3-14: Hardware Connections from the Arduino Board to the Digital Potentiometer

\begin{tabular}{|c|c|c|c|}
\hline \multicolumn{2}{|c|}{ From Arduino Board to AD5206 Chip } \\
\hline \multicolumn{2}{|c|}{ Arduino Board } & \multicolumn{2}{c|}{ AD5206 Chip } \\
\hline Pin & Description & Pin & Description \\
\hline 10 & SS & 5 & CS - Chip Select Input, Active Low \\
\hline 12 & MOSI & 7 & SDI - Serial Data Input, MSB first \\
\hline 13 & SCK & 8 & CLK - Serial Clock Input, positive edge triggered \\
\hline $5 V$ & 5 Volts & $5 V$ Rail & 5V Rail located on Bread Board \\
\hline & & Ground & Rail \\
GND & Ground & & Ground Rail located on Bread Board \\
\hline
\end{tabular}


Table 3-15: Hardware Connections from the AD5206 Chip to the Breadboard

\begin{tabular}{|c|c|c|c|}
\hline \multicolumn{4}{|c|}{ From AD5206 Chip to Breadboard } \\
\hline \multicolumn{2}{|r|}{ AD5206 Chip } & \multicolumn{2}{|c|}{ Breadboard } \\
\hline Pin & Description & Pin & Description \\
\hline 4 & GND & $\begin{array}{c}\text { Ground } \\
\text { Rail }\end{array}$ & Ground Rail located on Bread Board \\
\hline 6 & Vdd & 5V Rail & 5V Rail located on Bread Board \\
\hline 9 & Vss, Negative Power Supply & $\begin{array}{c}\text { Ground } \\
\text { Rail }\end{array}$ & Ground Rail located on Bread Board \\
\hline
\end{tabular}

Table 3-16: Hardware Connections from the AD5206 to the LM5117

\begin{tabular}{|c|c|c|c|}
\hline \multicolumn{4}{|c|}{ From AD5206 Chip to LM5117 } \\
\hline \multicolumn{2}{|c|}{ AD5206 Chip } & \multicolumn{2}{c|}{ LM5117 } \\
\hline Pin & Description & Pin & Description \\
\hline 16 & B1 - B Terminal of Pot & Positive Terminal & Positive Terminal of R16 \\
\hline & & Negative & \\
17 & W1 - Wiper Terminal of Pot & Terminal & Negative Terminal of R17 \\
\hline 19 & A1 - A Terminal of Pot & Open & \\
\hline
\end{tabular}

\section{7 - Code Set-Up Summary:}

The code shown in Figure 3-11 is the SPI initialization for the microcontroller to the digital potentiometer. The SPI.h library must be included in order to start the SPI initialization process. Pin 10 is selected on the microcontroller and is the hardware connection from the microcontroller to the digital potentiometer. Note that the digital potentiometer is the slave and the microcontroller is the master since the microcontroller is controlling the digital potentiometer. A setup() function is necessary to initialize that the pin 10 is an output so that it can send data to the digital potentiometer. The loop() function has a DigitalPotWrite(int address, int value) function that adjusts a specific potentiometer (int address) on the chip along with its corresponding resistor value (int value). Lastly, the DigitalPotWrite(int address, int value) function is defined as a function that will activate pin 10 (Chip Select Active Low) to send the 
data, write the address and the value, and will deactivate pin 10 once the microcontroller is finished choosing the resistor value of the digital potentiometer.

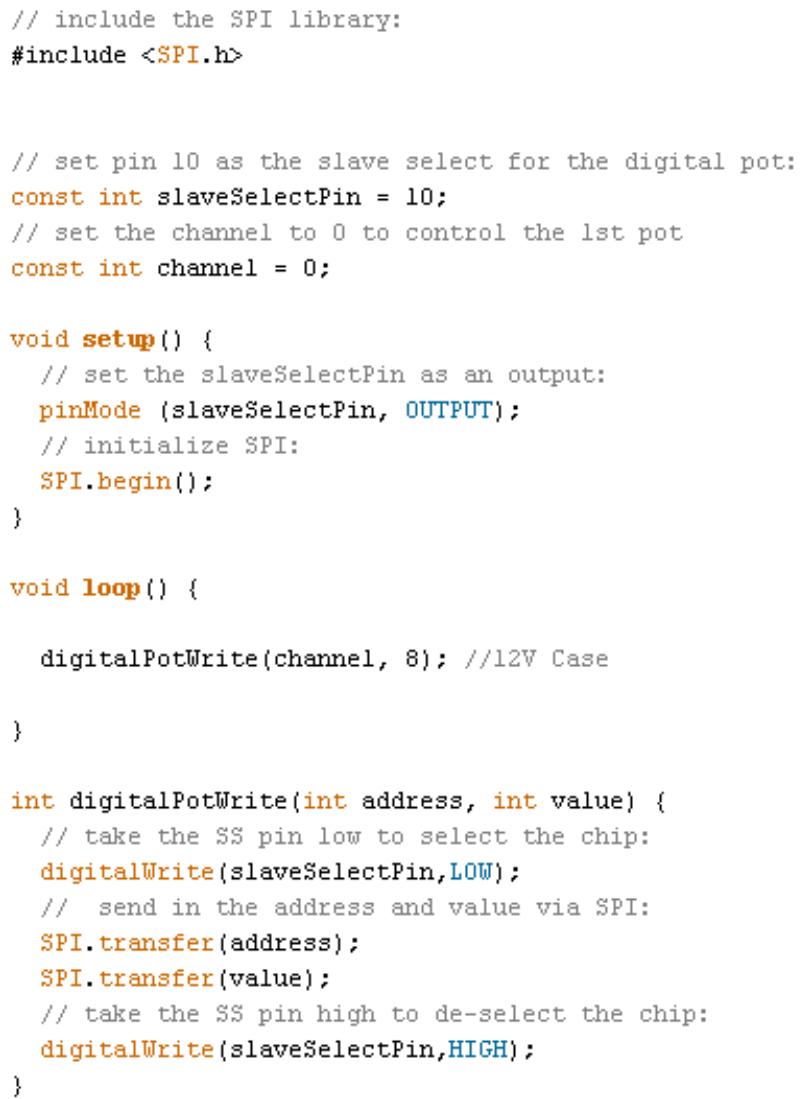

Figure 3-11: SPI Code Initialization and Digital Potentiometer Functionality [27]

\section{8 - Feedback Resistor Design:}

There are two resistors at the resistor divider and they both define the output voltage as shown in Figure 3-12. 


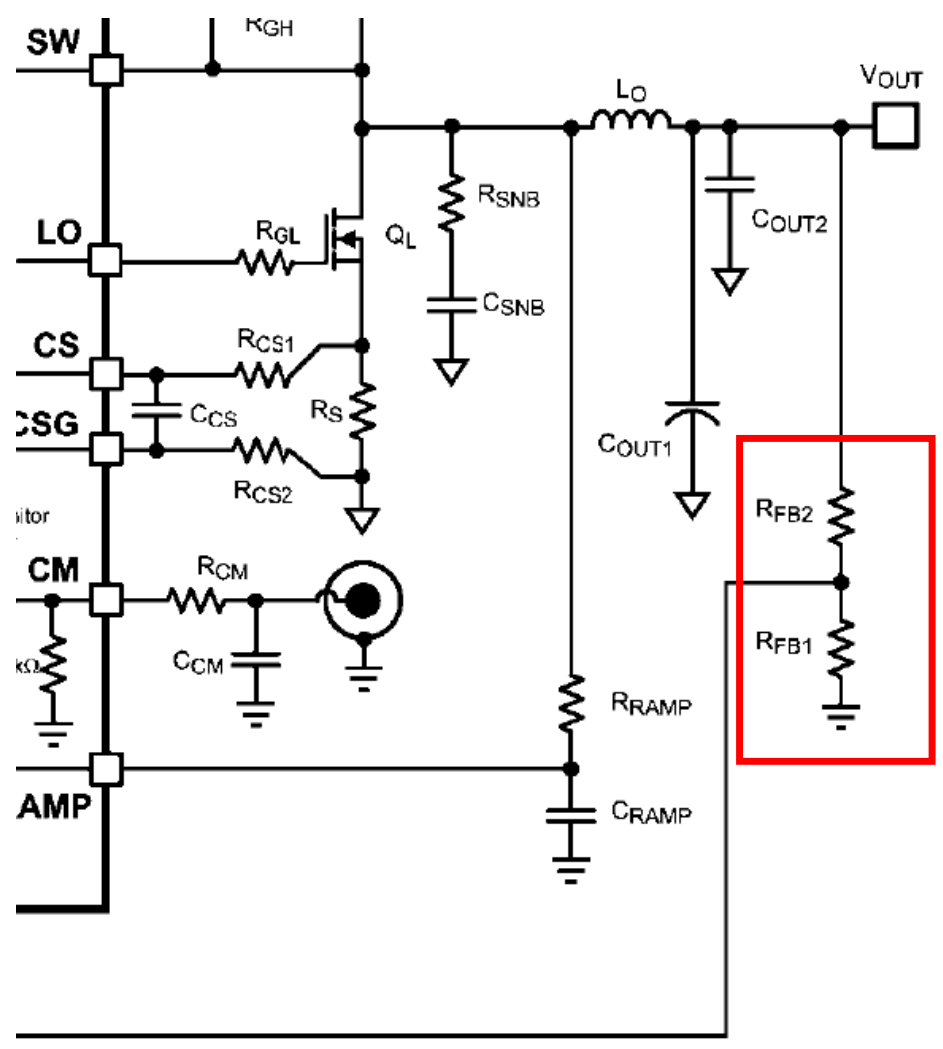

Figure 3-12: Output Resistor Divider $\left(\mathbf{R}_{\mathrm{FB} 2 \&} \mathbf{R}_{\mathrm{FB} 1}\right)$ [23]

It may therefore be possible to change either $\mathrm{R}_{\mathrm{FB} 2}$ and/or $\mathrm{R}_{\mathrm{FB} 1}$ to modify the output voltage, but to make the design simpler; it would be enough to keep one resistor constant while the other one is being varied. $\mathrm{R}_{\mathrm{FB} 2}$ is used as the fixed resistor since its value directly affects the frequency response of the converter, and hence its value is being used to further determine the compensation resistor $\mathrm{R}_{\mathrm{COMP}}$ in Equation 3-4:

$$
\mathrm{R}_{\mathrm{COMP}}=2
$$

\section{Equation 3-4: Calculation for Compensation Resistor}

Where, $\mathrm{R}_{\mathrm{s}}=$ Sense Resistor

$\mathrm{A}_{\mathrm{s}}=$ Current Sense Amplifier Gain

$\mathrm{C}_{\text {OUT }}=$ Output Capacitor

$\mathrm{R}_{\mathrm{FB} 2}=$ Feedback Resistor Divider 2

$\mathrm{F}_{\text {cross }}=$ Cross-Frequency 
This leaves the resistor $\mathrm{R}_{\mathrm{FB} 1}$ as the variable (digital potentiometer) resistor whose relationship with $\mathrm{R}_{\mathrm{FB} 2}$ and the output voltage follows Equation 3-5:

$$
\frac{R_{F B 2}}{R_{F B 1}}=\frac{V_{\text {out }}}{0.8 \mathrm{~V}}-1
$$

\section{Equation 3-5: Feedback Resistor Divider 2 and 1 Determine the Output Voltage}

$$
\begin{gathered}
\text { Where, } \mathrm{R}_{\mathrm{FB} 2}=\text { Feedback Resistor Divider } 2[\Omega] \\
\mathrm{R}_{\mathrm{FB} 1}=\text { Feedback Resistor Divider } 1[\Omega] \\
\mathrm{V}_{\text {out }}=\text { Output Voltage }[\mathrm{V}]
\end{gathered}
$$

Table 3-17: Expected Calculations for $R_{F B 1}$ when given $R_{F B 2}$ \& Vout

\begin{tabular}{|c|c|c|c|c|c|}
\hline $\begin{array}{c}\text { Vin } \\
(\mathrm{V})\end{array}$ & $\begin{array}{c}\text { Vout } \\
(\mathrm{V})\end{array}$ & $\begin{array}{c}\text { Iout } \\
(\mathrm{A})\end{array}$ & $\mathrm{R}_{\mathrm{FB} 2}(\Omega)$ & $\mathrm{R}_{\mathrm{FB} 1}(\Omega)$ & $\begin{array}{c}\text { Pout } \\
(\mathrm{W})\end{array}$ \\
\hline 48 & 5 & 10 & 5000 & 952.38 & 50 \\
\hline 48 & 6 & 8.33 & 5000 & 769.23 & 50 \\
\hline 48 & 7 & 7.14 & 5000 & 645.16 & 50 \\
\hline 48 & 8 & 6.25 & 5000 & 555.56 & 50 \\
\hline 48 & 9 & 5.55 & 5000 & 487.80 & 50 \\
\hline 48 & 10 & 5 & 5000 & 434.78 & 50 \\
\hline 48 & 11 & 4.54 & 5000 & 392.15 & 50 \\
\hline 48 & 12 & 4.16 & 5000 & 357.14 & 50 \\
\hline 48 & 13 & 3.84 & 5000 & 327.86 & 50 \\
\hline 48 & 14 & 3.57 & 5000 & 303.03 & 50 \\
\hline 48 & 15 & 3.33 & 5000 & 281.69 & 50 \\
\hline
\end{tabular}

Overall design requirements for the small wall plug are shown in Table 3-18 and a summary of components used for hardware implementation to construct the smart wall plug are shown in Table 3-19. 
Table 3-18: Summary of Design Requirements for the Smart Wall Plug

\begin{tabular}{|l|c|}
\hline Input Voltage (Vin) & $48 \mathrm{~V}_{\mathrm{DC}}$ \\
\hline $\begin{array}{l}\text { Output Voltage } \\
\text { (Vout) }\end{array}$ & $5 \mathrm{~V}_{\mathrm{DC}}$ to $15 \mathrm{~V}_{\mathrm{DC}}$ \\
\hline Output Current (Iout) & $3.33 \mathrm{~A}$ to $10 \mathrm{~A}$ \\
\hline Output Power (Pout) & $50 \mathrm{~W}$ \\
\hline $\begin{array}{l}\text { Nominal Switching } \\
\text { Frequency (F }\end{array}$ & $230 \mathrm{KHz}$ \\
\hline
\end{tabular}

Table 3-19: Summary of Components Used for Hardware Implementation to Construct the Smart Wall Plug

\begin{tabular}{|c|c|}
\hline Hardware & Hardware Application \\
\hline Buck Converter & LM5117 Evaluation Board \\
\hline Current Monitor & LM5117 Evaluation Board \\
\hline Microcontroller & Arduino Uno Board \\
\hline $\begin{array}{c}\text { Digital } \\
\text { Potentiometer }\end{array}$ & AD5206 (10k $\Omega)$ \\
\hline
\end{tabular}




\section{CHAPTER 4: DEVELOPMENT \& TESTING}

Before inserting and testing the digital potentiometer as the resistor divider R16, a preliminary test was conducted using a $5 \mathrm{k} \Omega$ resistor analog potentiometer for $\mathrm{R} 16$. This is to ensure that the converter would still operate properly with adjustable network divider. The positive terminal of the analog potentiometer was connected to the positive pad of R16, while the wiper terminal of the analog potentiometer was connected to the negative pad of R16 shown in Figure 4-1. The negative terminal of the analog potentiometer was deliberately left open since either positive or negative terminals can be used to vary the resistance.

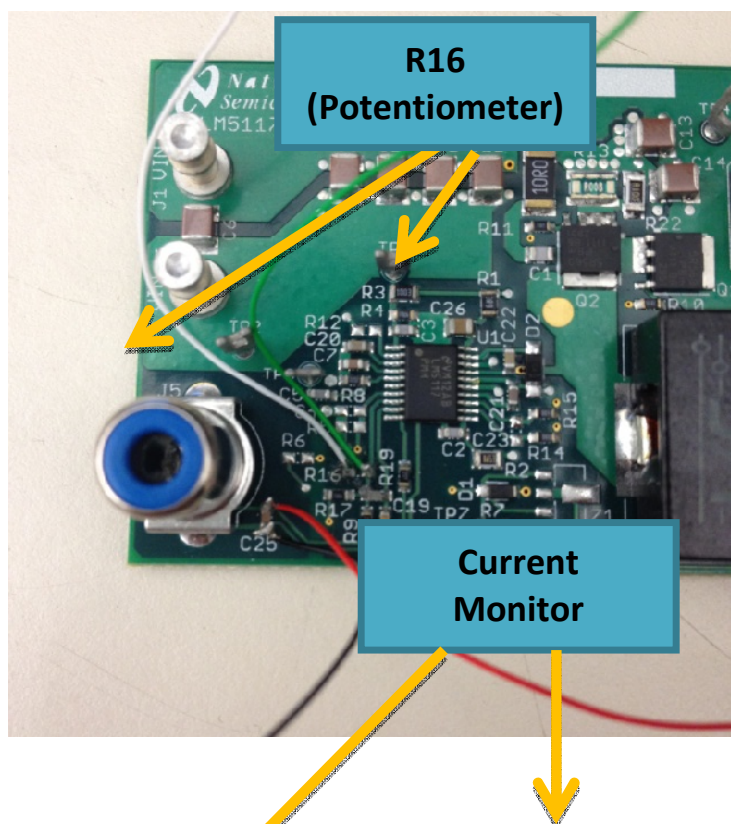

Figure 4-1: R16 Connection with the rotentiometer (Positive Terminal as white wire and negative terminal as green wire)

As the analog potentiometer resistance is varied, the output voltage varies. This proves that changing divider network resistor R16 will indeed output different voltages. The digital potentiometer was then inserted to replace the analog potentiometer. 
The digital potentiometer works similarly like the analog potentiometer in that it has the same connections: two terminals and a wiper. In this case, the B terminal is connected to the positive terminal to R16 and the $\mathrm{W}$ terminal is connected to the negative terminal of $\mathrm{R} 16$. The connections are crucial because a wrong connection can produce a wrong output resistance value depending on the design of the digital potentiometer. For example, in this design, increasing the digital potentiometer means increasing the analog resistance. The number of steps to initiate different resistor value is shown in Table 3-14. In order for this design to be valid, terminal A of the digital potentiometer must be open circuited, where terminal B is connected to one of the terminals of R16.

The digital potentiometer output resistances are measured for proper functionality. A range of digital resistances was chosen based on the requirements of the output voltages. Although the wall outlet is designed for $5 \mathrm{~V}-15 \mathrm{~V}$, it would make sense to set the voltage at the lowest, reasonable number to power up the appliance. It would be appropriate to start at $0 \mathrm{~V}$ and up, but the LM5117 is designed for an output voltage of 12V. For testing purposes, the converter will start at $6 \mathrm{~V}$ (for $9 \mathrm{~V}$ radio and $12 \mathrm{~V}$ radio) and will ramp up until the converter finds the appliance's input voltage rating.

Table 4-1: Measured Output Resistance Values from the AD5206

\begin{tabular}{|c|c|c|}
\hline $\begin{array}{c}\text { Digital } \\
\text { Resistance } \\
\text { Value }\end{array}$ & $\begin{array}{c}\text { Output } \\
\text { Voltage } \\
(\text { V) }\end{array}$ & $\begin{array}{c}\text { Measured } \\
\text { Resistance Value } \\
(\text { ohm })\end{array}$ \\
\hline
\end{tabular}




\begin{tabular}{|c|c|c|}
\hline (Decimal) & & \\
\hline 18 & 6.09 & 749 \\
\hline 17 & 6.37 & 710 \\
\hline 16 & 6.73 & 668 \\
\hline 15 & 7.10 & 628.7 \\
\hline 14 & 7.53 & 588.3 \\
\hline 13 & 8 & 550.0 \\
\hline 12 & 8.53 & 509.5 \\
\hline 11 & 9.2 & 471.3 \\
\hline 10 & 10 & 430.8 \\
\hline 9 & 10.89 & 392.4 \\
\hline 8 & 12.05 & 361 \\
\hline
\end{tabular}

Three appliances with different voltage ratings are tested: the $12 \mathrm{~V}$ radio, the $9 \mathrm{~V}$ radio, and the $6 \mathrm{~V} \mathrm{TV}$. These appliances are chosen because of the wide range of testable voltages they offer which will be suitable to test the proposed smart wall plug against the design requirements of $5 \mathrm{~V}$ to $15 \mathrm{~V}$. Limited dc load and their associated cost also present the issue in including more appliances to test. For testing purposes, a $0.75 \mathrm{~A}$ fuse is connected to the output for the $12 \mathrm{~V}$ radio, $1 \mathrm{~A}$ fuse for the $9 \mathrm{~V}$ radio, and the $0.5 \mathrm{~A}$ for the $\mathrm{DC} \mathrm{TV}$. Images of each appliances are provided below, along with their ratings in Figures 4-2 to Figure 4-4.
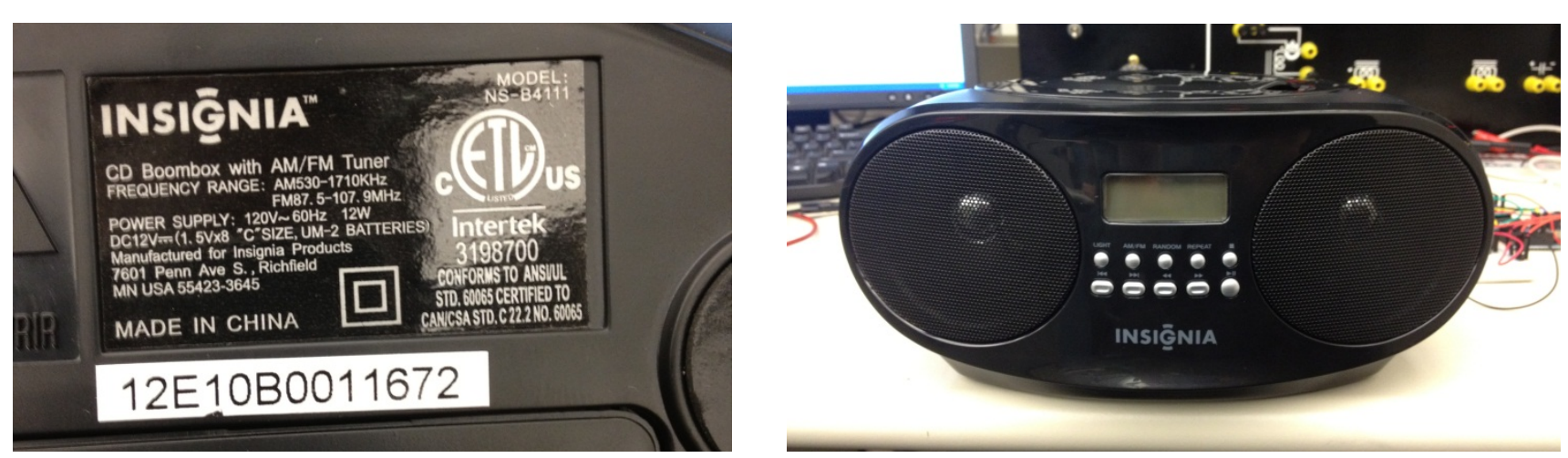
Figure 4-2: 12V Radio and its ratings

Table 4-2: Ratings for the $12 \mathrm{~V}$ Radio

\begin{tabular}{|c|c|c|c|c|}
\hline Vmin & Vmax & Voltage Rating & Power Rating & Current Rating \\
\hline $7 \mathrm{~V}$ & $14 \mathrm{~V}$ & $12 \mathrm{~V}$ & $12 \mathrm{~W}$ & $1 \mathrm{~A}$ \\
\hline
\end{tabular}
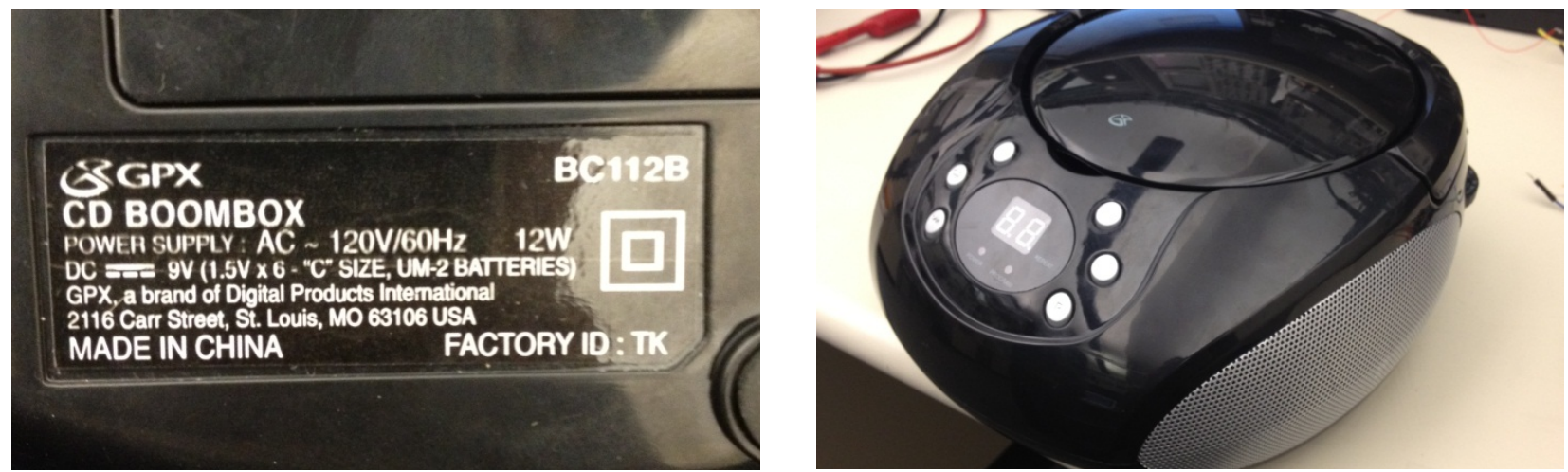

Figure 4-3: 9V Radio and its ratings

Table 4-3: Ratings for the 9V Radio

\begin{tabular}{|c|c|c|c|c|}
\hline Vmin & Vmax & Voltage Rating & Power Rating & Current Rating \\
\hline $4 \mathrm{~V}$ & $12 \mathrm{~V}$ & $9 \mathrm{~V}$ & $12 \mathrm{~W}$ & $1.33 \mathrm{~A}$ \\
\hline
\end{tabular}
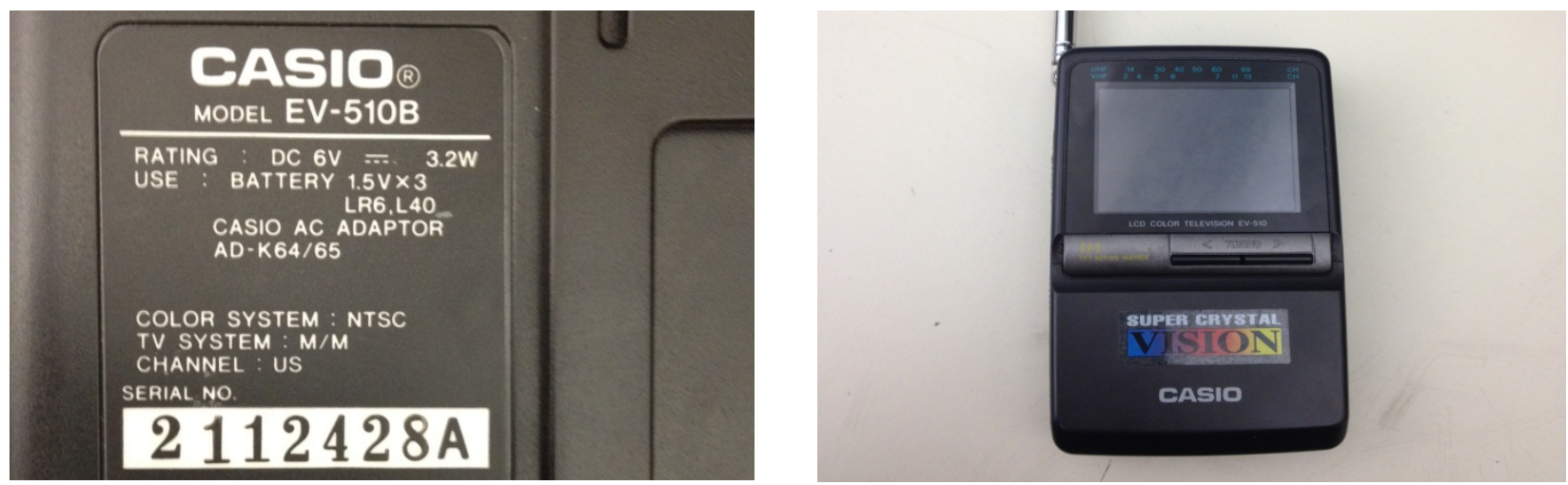

Figure 4-4: 6V DC TV and its ratings

Table 4-4: Ratings for the $6 \mathrm{~V}$ TV

\begin{tabular}{|c|c|c|c|c|}
\hline Vmin & Vmax & Voltage Rating & Power Rating & Current Rating \\
\hline $2.5 \mathrm{~V}$ & $8 \mathrm{~V}$ & $6 \mathrm{~V}$ & $3.2 \mathrm{~W}$ & $0.533 \mathrm{~A}$ \\
\hline
\end{tabular}


The overall test set up in shown below in Figure 4-5. This is the physical representation of the system from the block diagram of Figure 1-1. Since all system blocks are tested and verified, it is necessary to interface all the connections to design the whole DC wall plug. More information and description are shown in Table 4-5.

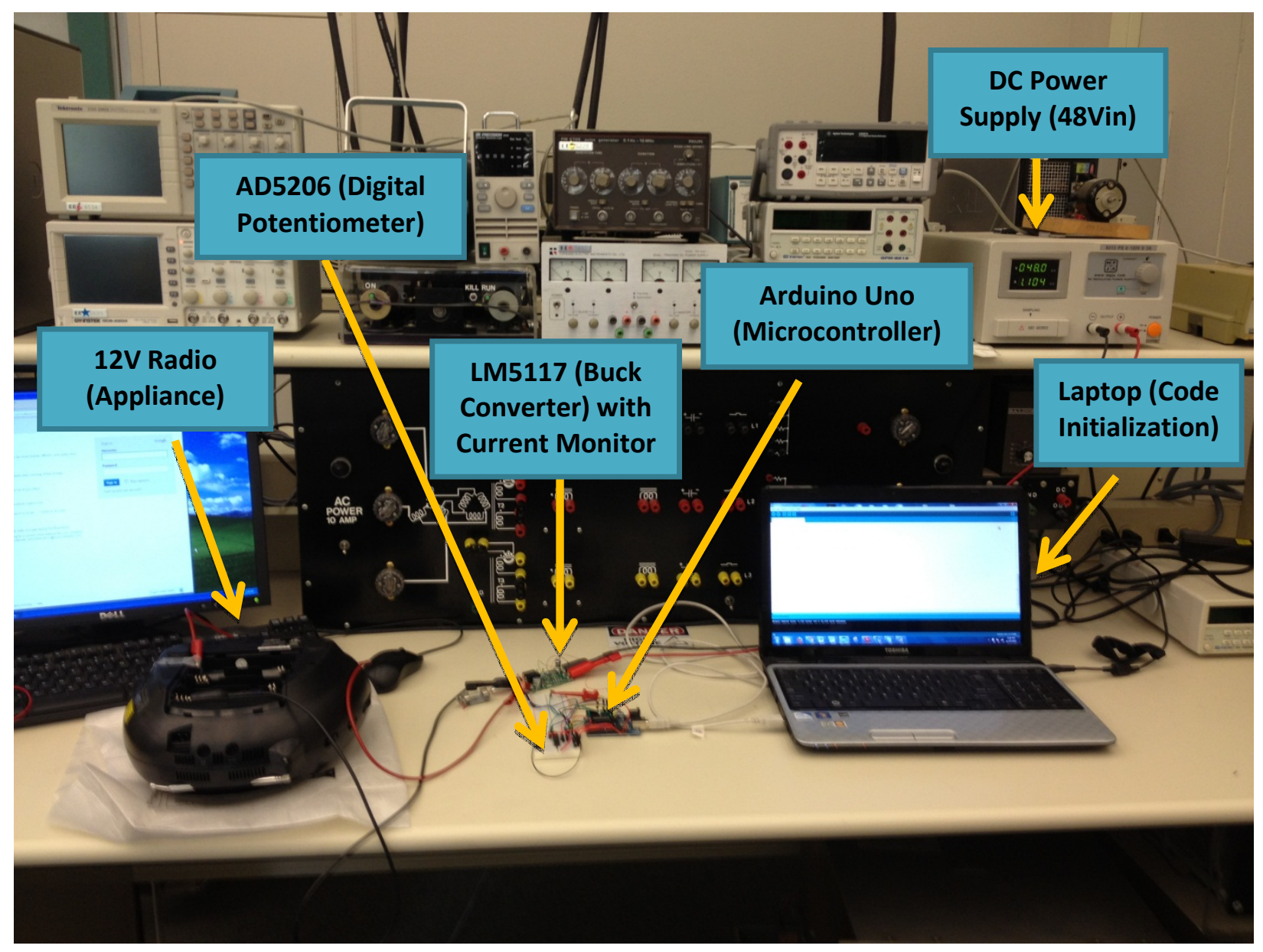

Figure 4-5: Overall Test Set up for DC Wall Plug

Table 4-5: Test Set up Description of all equipment used

\begin{tabular}{|c|c|}
\hline Equipment & Purpose \\
\hline Power Supply & $\begin{array}{l}\text { To supply } 48 \text { Volts DC to the input for the buck } \\
\text { converter }\end{array}$ \\
\hline $\begin{array}{l}\text { Digital Multi- } \\
\text { meter }\end{array}$ & $\begin{array}{l}\text { To measure output voltage and resistance values at } \\
\text { the digital potentiometer }\end{array}$ \\
\hline Laptop & $\begin{array}{l}\text { To upload code to the microcontroller so that it can } \\
\text { control the digital potentiometer }\end{array}$ \\
\hline
\end{tabular}




\begin{tabular}{|c|c|}
\hline Microcontroller & $\begin{array}{l}\text { To be able to interface with the digital potentiometer } \\
\text { and read current monitor information }\end{array}$ \\
\hline $\begin{array}{c}\text { Buck } \\
\text { Converter }\end{array}$ & $\begin{array}{c}\text { To step down the } 48 \text { Volt input to different output } \\
\text { voltages }\end{array}$ \\
\hline 9V Radio & $9 \mathrm{~V}$ appliance used as a load \\
\hline 12V Radio & $12 \mathrm{~V}$ appliance used as a load \\
\hline 6V Radio & 6V appliance used as a load \\
\hline
\end{tabular}

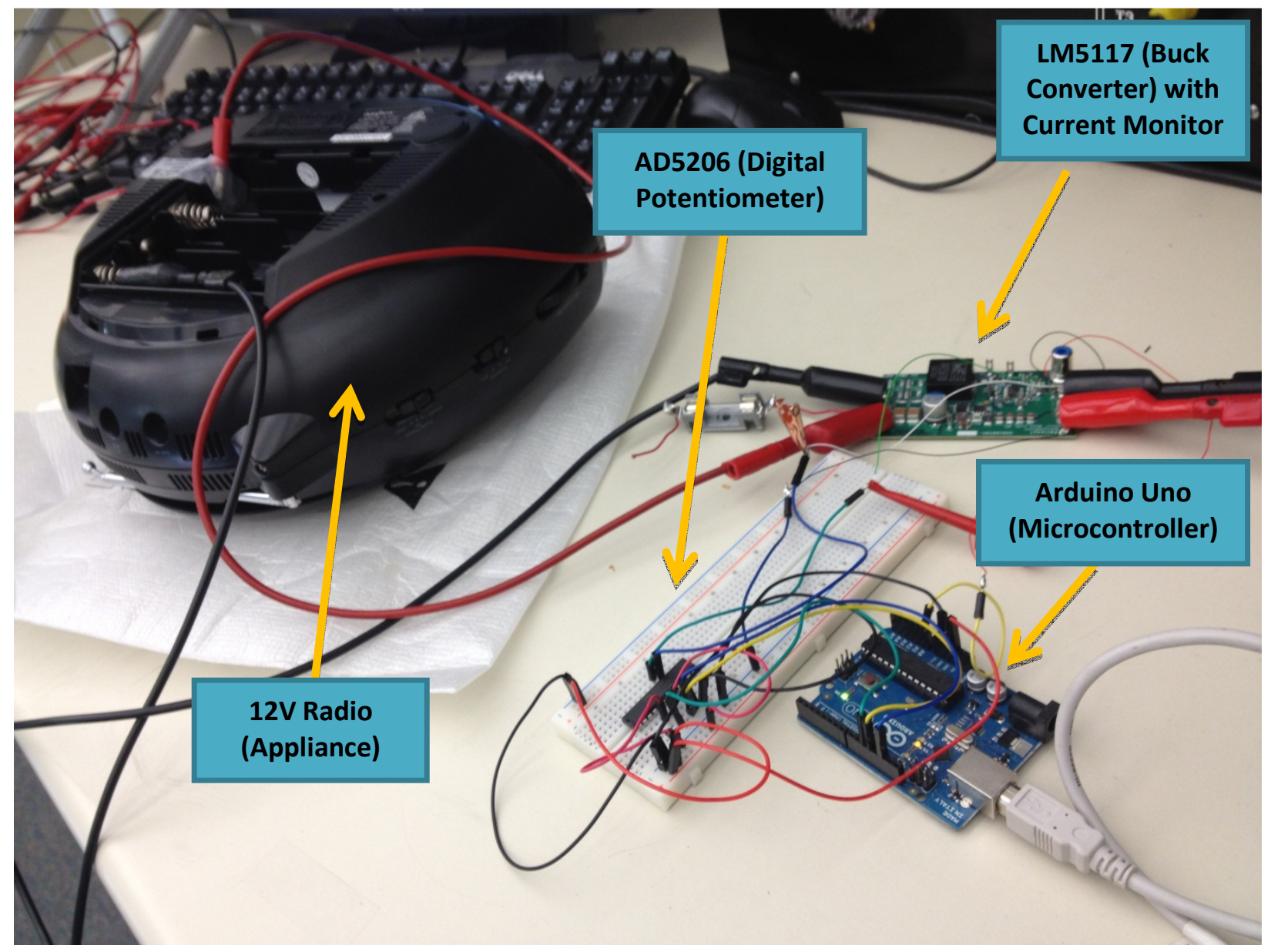

Figure 4-6: Close up \& Side View of the test set up for the Radio, LM5117, Arduino Uno and the AD5206

The next step is to design the behavior of the proposed wall plug design. The behavior accounts for when the converter stops increasing its voltage. This occurs when the appliance's operating voltage rating is met. There are four methods that determine the output voltage's behavior as shown in Table 4-6. Discussion on each method follows. 


\section{Table 4-6: Different of methods that make up the output voltage's behavior}

\begin{tabular}{|c|c|}
\hline Method & Description \\
\hline Method \#1 & $\begin{array}{c}\text { Existence of Current at Input of } \\
\text { Appliance }\end{array}$ \\
\hline Method \#2 & $\Delta \mathrm{I}$ - Differences in Current \\
\hline Method \#3 & 10 Trials for Current Monitoring \\
\hline Method \#4 & Algorithm Accuracy \\
\hline
\end{tabular}

Each appliance has a different input voltage rating. In order to determine the input voltage rating or the turn-on voltage, it is assumed that current will flow from the converter to the appliance when the input voltage rating is reached. In order to prove this, a hardware simulation test (Method \#1) is developed to prove this concept. A power supply is directly connected to the $12 \mathrm{~V}$ radio and the power supply slowly ramps up its voltage for the radio. The voltage starts from 0 to its nominal voltage rating of $12 \mathrm{~V}$. Each output voltage and its current are recorded in steps of $0.5 \mathrm{~V}$ as shown in Table 4-7. A graphical representation is also recorded to show that there is a "jump" of current when the appliance is on. The jump occurs at $6.5 \mathrm{~V}$, which is the minimum input voltage rating for the $12 \mathrm{~V}$ radio. Note from Table $4-7$, when load current exists, the current fluctuates when the appliance is on at $6.5 \mathrm{~V}$. Because the current is fluctuating, all possible current values are recorded in Table 4-7 for each output voltage. When the voltage actually meets its rating at $12 \mathrm{~V}$, the current is finally stable. Method $\# 1$ is also applied to the $9 \mathrm{~V}$ radio and the 6V TV, which is shown in Table 4-8 and 4-9. 
Table 4-7: Vout and Iout for 12V Radio

\begin{tabular}{|c|c|c|c|c|c|c|}
\hline Vout (V) & \multicolumn{7}{|c|}{ All Possible Iout (A) Results } \\
\hline 0 & 0 & & & & & \\
\hline 0.5 & 0 & & & & & \\
\hline 1 & 0 & & & & & \\
\hline 1.5 & 0 & & & & & \\
\hline 2 & 0 & & & & & \\
\hline 2.5 & 0 & & & & & \\
\hline 3 & 0 & & & & & \\
\hline 3.5 & 0 & & & & & \\
\hline 4 & 0 & & & & & \\
\hline 4.5 & 0 & & & & & \\
\hline 5 & 0 & & & & & \\
\hline 5.5 & 0 & & & & & \\
\hline 6 & 0 & & & & & \\
\hline 6.5 & 0.08 & 0.0841 & 0.094 & 0.09 & 0.08 & 0.091 \\
\hline & & & & & & \\
\hline 7 & 0.09 & 0.089 & 0.084 & & & \\
\hline 7.5 & 0.085 & 0.094 & 0.095 & & & \\
\hline 8 & 0.109 & 0.098 & 0.089 & 0.088 & & \\
\hline 8.5 & 0.097 & 0.09 & & & & \\
\hline 9 & 0.105 & 0.096 & 0.083 & 0.086 & & \\
\hline 9.5 & 0.1 & 0.093 & 0.009 & 0.105 & & \\
\hline 10 & 0.1 & 0.095 & & & & \\
\hline 10.5 & 0.1 & & & & & \\
\hline 11 & 0.105 & & & & & \\
\hline 11.5 & 0.109 & & & & & \\
\hline 12 & 0.095 & & & & & \\
\hline
\end{tabular}




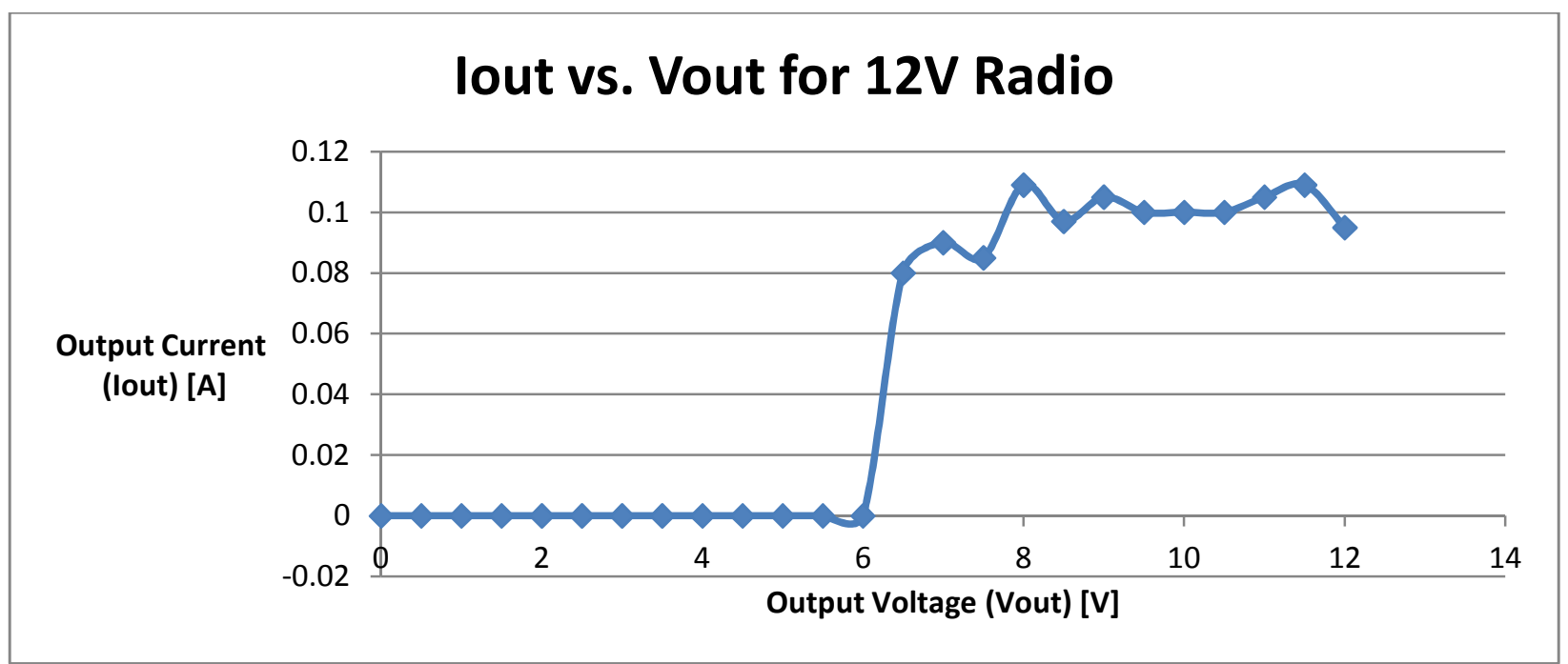

Figure 4-7: Iout vs Vout for 12V Radio

The same test was applied for the $9 \mathrm{~V}$ radio whose result is presented in Table 4-8 and Figure 4-8. From observations and data, the 9V radio surprisingly has a different 'turn-on' behavior than the $12 \mathrm{~V}$ radio. At $1 \mathrm{~V}$, current actually exists, but by observation the $9 \mathrm{~V}$ radio is not on. As the voltage increases, the minimum input voltage is found to be $4 \mathrm{~V}$ and indeed current still exists. Since this behavior exists, the assumption of existing current is no longer valid for an appliance to turn on. Another observation from Table 4-8 is that the current still fluctuates at the rated voltage of $9 \mathrm{~V}$. From the $12 \mathrm{~V}$ radio, the current is found to be stable as expected, but the $9 \mathrm{~V}$ radio is unstable. 
Table 4-8: Vout and Iout Data for 9V Radio

\begin{tabular}{|c|c|r|r|r|r|r|l|}
\hline $\begin{array}{c}\text { Vout } \\
(\mathbf{V})\end{array}$ & \multicolumn{9}{|c|}{ All Possible Iout (A) Results } \\
\hline 0 & 0 & & & & & & \\
\hline 0.5 & 0 & & & & & & \\
\hline 1 & 0 & 0.002 & & & & & \\
\hline 1.5 & 0.001 & & & & & & \\
\hline 2 & 0.003 & & & & & & \\
\hline 2.5 & 0.007 & & & & & & \\
\hline 3 & 0.013 & & & & & & \\
\hline 3.5 & 0.024 & & & & & & \\
\hline 4 & 0.03 & & & & & & \\
\hline 4.5 & 0.034 & 0.037 & & & & & \\
\hline 5 & 0.036 & 0.042 & 0.043 & 0.04 & & & \\
\hline 5.5 & 0.041 & 0.044 & 0.045 & & & & \\
\hline 6 & 0.043 & 0.049 & 0.045 & 0.046 & 0.051 & 0.044 & \\
\hline 6.5 & 0.048 & 0.046 & 0.045 & 0.05 & 0.051 & 0.048 & \\
\hline 7 & 0.047 & 0.05 & 0.048 & 0.051 & & & \\
\hline 7.5 & 0.049 & 0.053 & 0.048 & 0.051 & 0.049 & 0.054 & 0.052 \\
\hline 8 & 0.05 & 0.052 & 0.054 & 0.051 & & & \\
\hline 8.5 & 0.053 & 0.055 & 0.057 & & & & \\
\hline 9 & 0.056 & 0.056 & 0.054 & 0.057 & & & \\
\hline
\end{tabular}

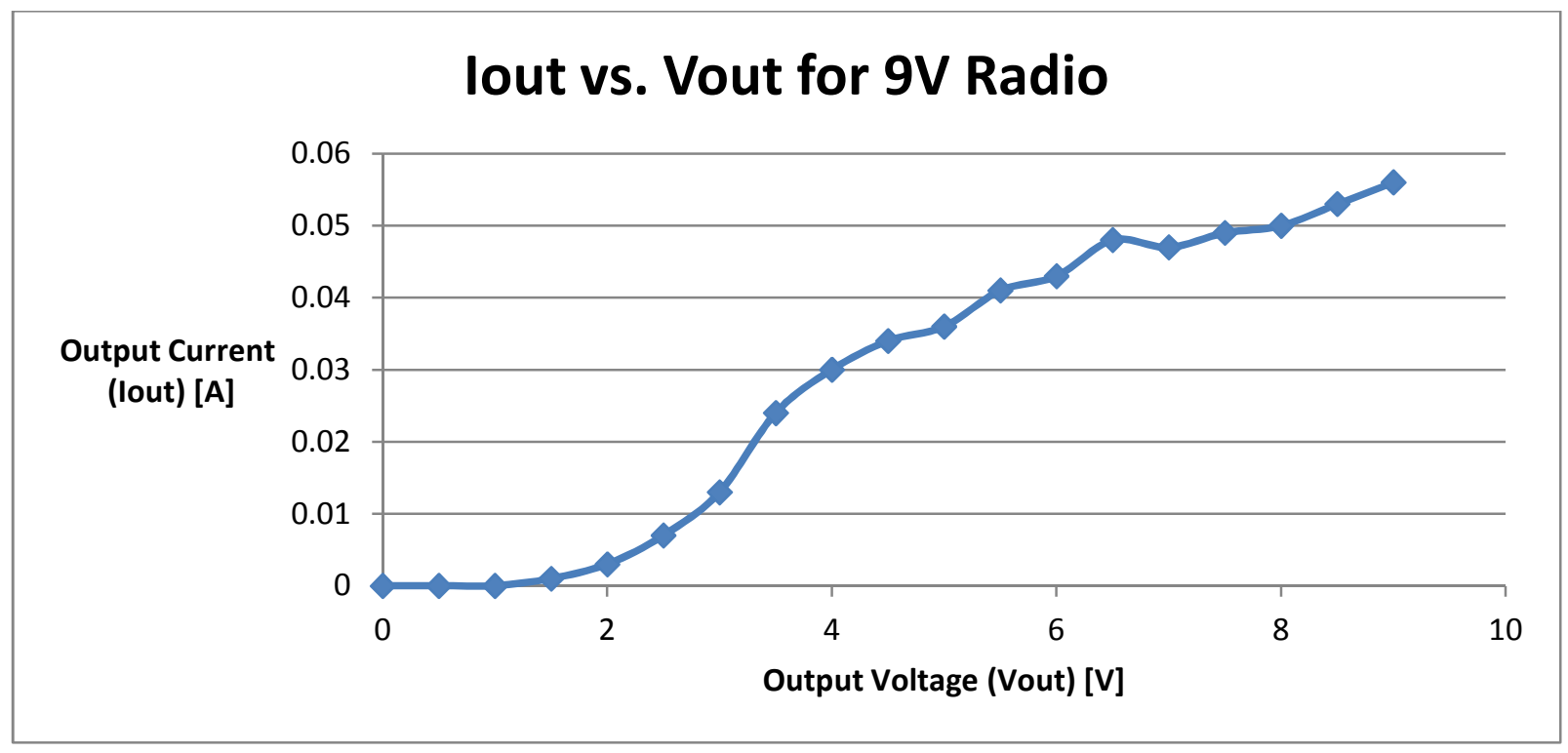

Figure 4-8: Iout vs Vout for 9V Radio 
The same test was also applied to the 6V TV yielding Table 4-9 and Figure 4-9. Just like the $9 \mathrm{~V}$ radio, similar behavior occurs in the $6 \mathrm{~V} \mathrm{TV}$ in that current starts to flow at $1 \mathrm{~V}$, even though the minimum input voltage rating is $2.5 \mathrm{~V}$. The current was also observed to be fluctuating at its rated voltage of $6 \mathrm{~V}$.

Table 4-9: Vout and Iout Data for 6V TV

\begin{tabular}{|c|c|r|r|r|r|r|r|}
\hline $\begin{array}{c}\text { Vout } \\
(\mathbf{V})\end{array}$ & \multicolumn{7}{|c|}{ All Possible Iout (A) Results } \\
\hline 0 & 0 & & & & & & \\
\hline 0.5 & 0 & & & & & & \\
\hline 1 & 0.014 & & & & & & \\
\hline 1.5 & 0.137 & 0.134 & 0.136 & & & & \\
\hline 2 & 0.248 & 0.249 & 0.251 & 0.251 & 0.255 & & \\
\hline 2.5 & 0.591 & 0.586 & 0.587 & 0.584 & 0.583 & 0.589 & \\
\hline 3 & 0.543 & 0.54 & 0.548 & 0.548 & 0.546 & & \\
\hline 3.5 & 0.503 & 0.507 & 0.5 & 0.506 & 0.512 & 0.496 & 0.51 \\
\hline 4 & 0.47 & 0.468 & 0.479 & 0.469 & 0.468 & 0.468 & 0.474 \\
\hline 4.5 & 0.447 & 0.446 & 0.451 & 0.448 & 0.458 & 0.452 & 0.453 \\
\hline 5 & 0.434 & 0.436 & 0.433 & 0.445 & 0.441 & 0.437 & 0.44 \\
\hline 5.5 & 0.426 & 0.43 & 0.44 & 0.43 & 0.426 & 0.438 & 0.424 \\
\hline 6 & 0.419 & 0.437 & 0.42 & 0.4212 & 0.425 & 0.418 & 0.421 \\
\hline
\end{tabular}

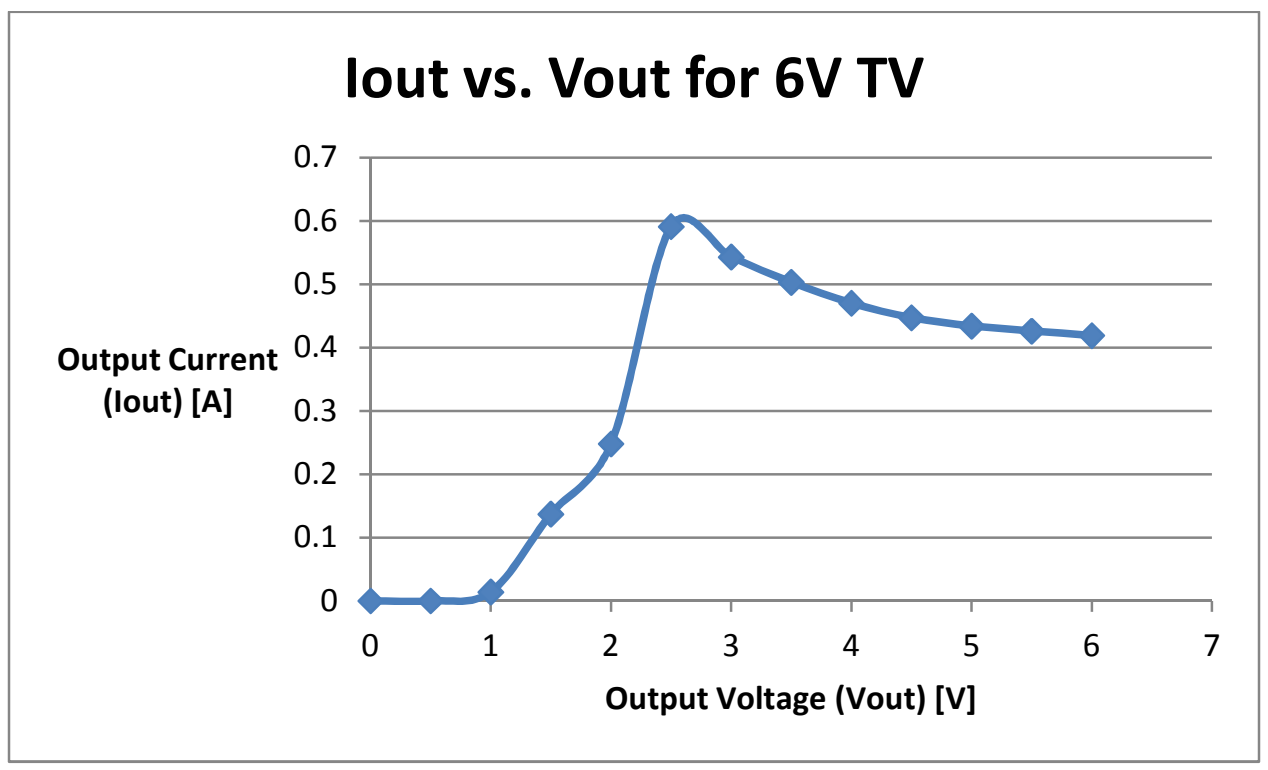

Figure 4-9: Iout vs Vout for 6V TV 
Based on the previous observation that current may actually start at lower than the minimum operating voltage of the load, therefore an improved method was developed to better achieve the targeted voltage. This was done by noticing that there is indeed a 'turn-on' voltage if the difference of currents is calculated (Method \#2). In other words, the first method will be implemented as the initial observation test in the algorithm, whereas the second method will be used to achieve a closer operating voltage based on calculations done by the algorithm. The calculation takes the difference of currents ( $\Delta$ Iout) for two output voltages from the last test and current test as shown in Equation 4-1. The new method was applied to the $12 \mathrm{~V}$ radio, $9 \mathrm{~V}$ radio, and 6V TV. Results were listed on Tables 4-10 to 4-12, and Figures 4-10 to 4-12. An example of how ( $\Delta$ Iout) is calculated in Method \#2 is below:

For 9V (0.056A) and 8V (0.050A):

$$
0.056 A-0.050 A=0.006 A=\Delta I o u t
$$

\section{Equation 4-1: Difference Calculation between Two Currents for Two Output Voltages}

Table 4-10: Vout and $\Delta$ Iout Data for 12V Radio

\begin{tabular}{|c|c|}
\hline $\begin{array}{c}\text { Vout } \\
(\mathbf{V})\end{array}$ & $\begin{array}{c}\Delta \text { Iout } \\
(\mathbf{A})\end{array}$ \\
\hline 0 & 0 \\
\hline 1 & 0 \\
\hline 2 & 0 \\
\hline 3 & 0 \\
\hline 4 & 0 \\
\hline 5 & 0 \\
\hline 6 & 0 \\
\hline 7 & 0.09 \\
\hline 8 & 0.019 \\
\hline 9 & -0.004 \\
\hline 10 & -0.005 \\
\hline 11 & 0.005 \\
\hline 12 & -0.01 \\
\hline
\end{tabular}




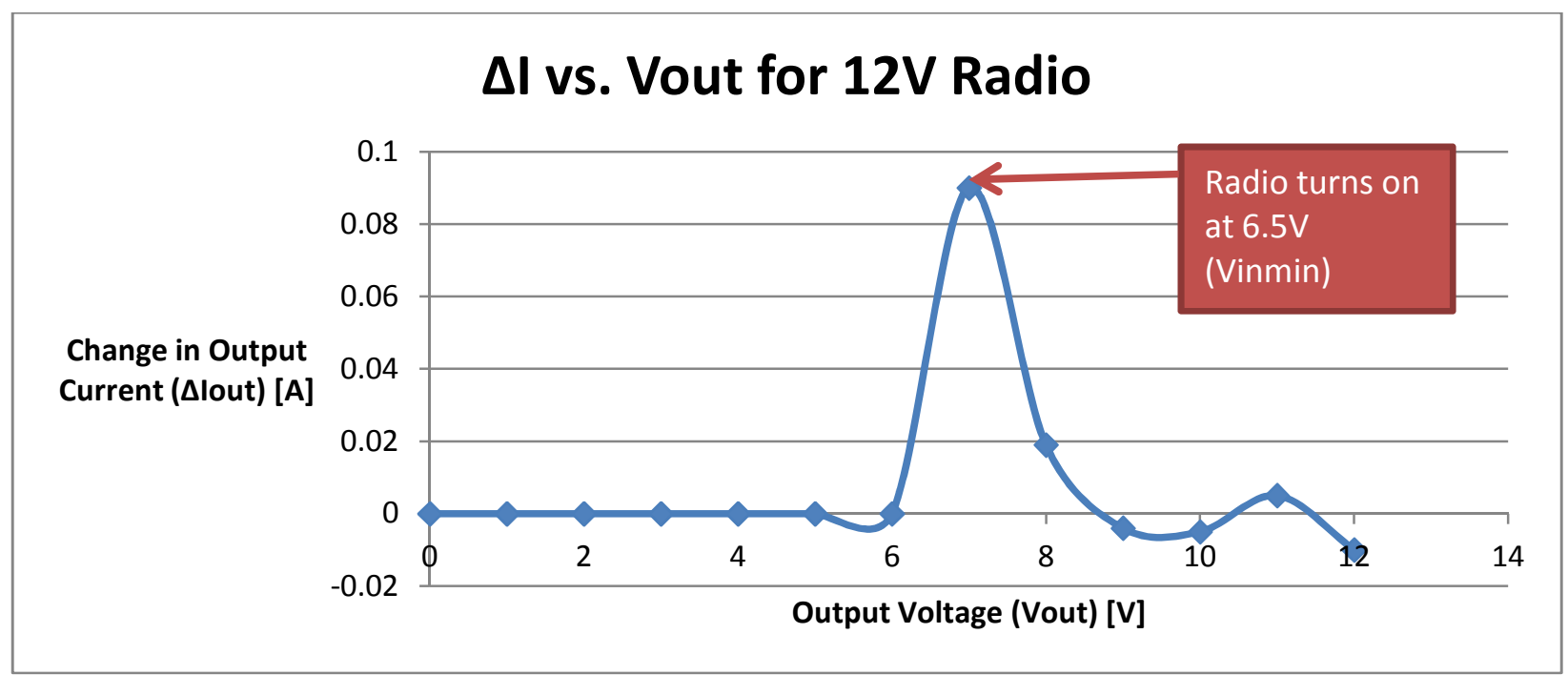

Figure 4-10: $\Delta$ Iout vs Vout for 12V Radio

Table 4-11: Vout and $\Delta$ Iout for $9 \mathrm{~V}$ Radio

\begin{tabular}{|c|c|}
\hline $\begin{array}{c}\text { Vout } \\
(\mathbf{V})\end{array}$ & $\begin{array}{c}\Delta \text { Iout } \\
(\mathbf{A})\end{array}$ \\
\hline 0 & 0 \\
\hline 1 & 0 \\
\hline 2 & 0.003 \\
\hline 3 & 0.01 \\
\hline 4 & 0.017 \\
\hline 5 & 0.006 \\
\hline 6 & 0.007 \\
\hline 7 & 0.004 \\
\hline 8 & 0.003 \\
\hline 9 & 0.006 \\
\hline
\end{tabular}




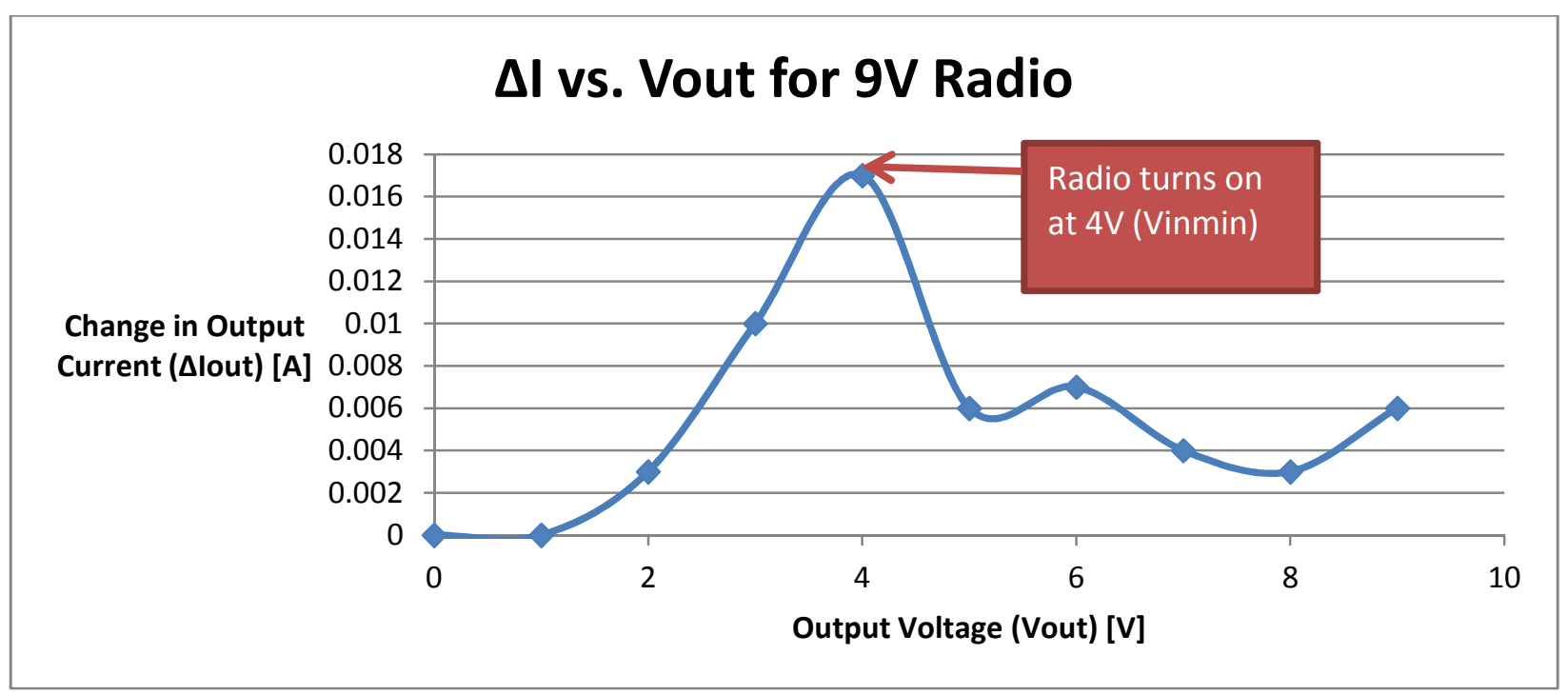

Figure 4-11: $\Delta$ Iout vs Vout for 9V Radio

Table 4-12: Vout and $\Delta$ Iout data for $6 \mathrm{~V} T \mathrm{TV}$

\begin{tabular}{|c|c|}
\hline Vout $(\mathbf{V})$ & $\begin{array}{c}\Delta \text { Iout } \\
(\mathbf{A})\end{array}$ \\
\hline 0 & 0 \\
\hline 1 & 0.014 \\
\hline 2 & 0.234 \\
\hline 3 & 0.295 \\
\hline 4 & -0.073 \\
\hline 5 & -0.036 \\
\hline 6 & -0.015 \\
\hline
\end{tabular}




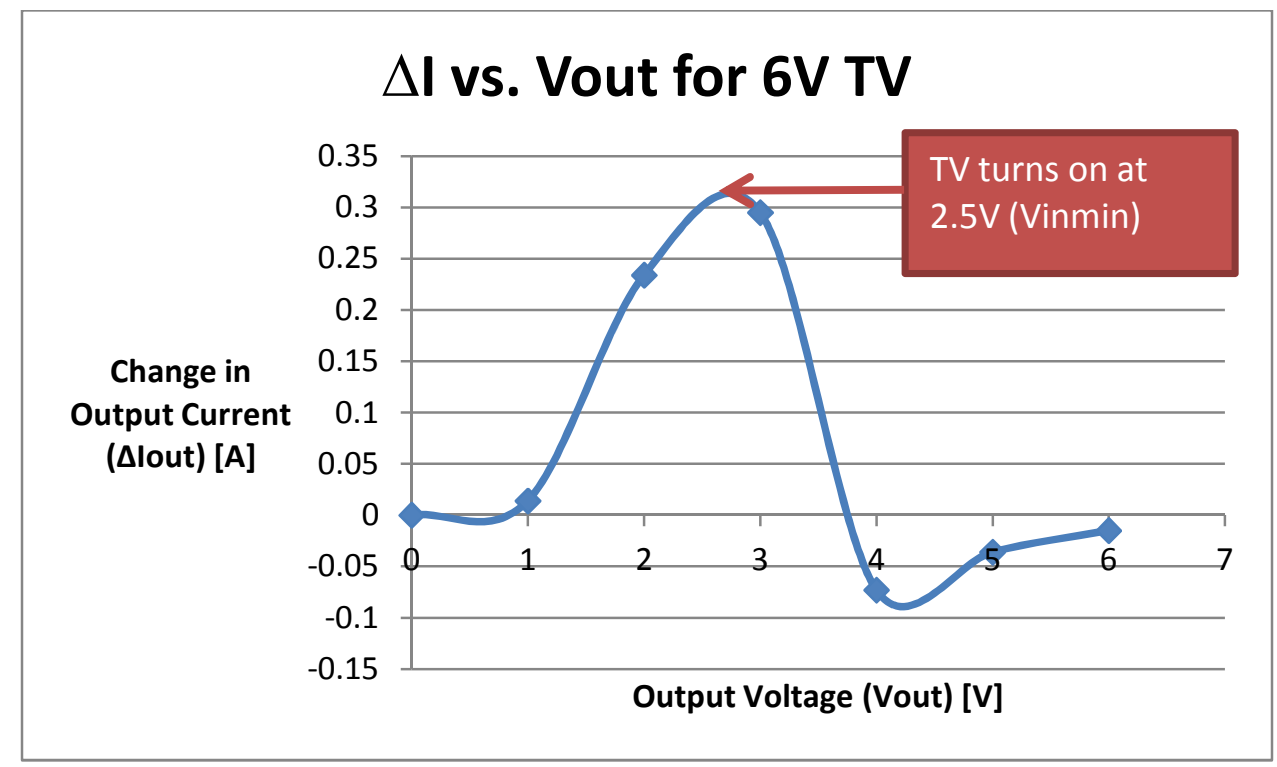

Figure 4-12: $\Delta$ Iout vs Vout for 6V TV

The highest change in current means the minimum input voltage rating has been detected. For example, in Figure 4-12, the maximum value of the graph denotes the turn-on voltage of the 6V TV.

Now that the turn-on voltages can be detected, the next step is to read these currents into the microcontroller so that the microcontroller knows when to stop increasing its output voltage. The output current is connected to the microcontroller and is able to convert analog voltages to digital values for the microcontroller through an ADC (analog-to-digital converter). During tests on the same loads, it was observed that as voltage was being read to the microcontroller, the digital voltages were fluctuating. This is expected because as mentioned earlier in Tables 4-7, 48 , and 4-9, current constantly changes when the appliance is on. This became the main concern where a static threshold must be found to tell when the converter should stop increasing its voltage. Finding a static threshold is not a trivial task because the physical appliance allows for fluctuating currents. 
In order to somewhat achieve a static threshold, ten trials of the current monitor information are recorded in Tables 4-13 to 4-15. This is called Method \#3 which will be added in conjunction with the previous two methods in the algorithm. From these tables, patterns and trends can be observed to create conditions so that a static threshold is possible. For example, in Tables 4-13 to 4-15, each appliance is off when a digital voltage is $0-4$. Each appliance can be on if one of the digital voltages in that trial is greater than 4. Note that minimum approximated turnon voltage is denoted by the red block.

However, not all appliances meet their minimum input voltage ratings just because one of their digital values is greater than 4 . Therefore, another condition must be met in order to make a valid static threshold. Another pattern is observed again in Tables 4-13, 4-14, and 4-15. The pattern is that once the appliance reaches its voltage rating, the current seems to be more stable than other output voltages. If the second method was applied to the currents, the difference between the trials is 0,1 , or 2 . From the digital information, it can be assumed that the smallest difference of current means that the appliance has reached is rated voltage. Therefore, this condition can be added to the static threshold. The summary of conditions that make up the static threshold is shown below:

1) The current monitor must be greater than the value of 10 for the appliance to be on (observations from Tables)

2) Delta for each trial must equal $-2,-1,0,1$, or 2 to show a possibility that the current is steady (assuming that $80 \%$ of the time the current monitor value stays within its stable current, where as $20 \%$ of the time current can jump dramatically high or low - observed from Tables 4-13, 4-14, 4-15 below) 
If most or all trials meet the threshold requirement, the output voltage will stop increasing and will assume that it has met the appliance's voltage rating. In order to keep track of all the trials met, a counter is used. If the delta equals to $-2,-1,0,1$, or 2 , a counter will increment. If the counter is greater or equal to 8 , then the output voltage will stop increasing and will continue to supply the appliance. The number 8 is chosen because it accounts for the $80 \%$ of the time current monitor stays within its stable current, where $20 \%$ of the time current can jump dramatically high or low as mentioned earlier.

Table 4-13: Current monitor digital output for $12 \mathrm{~V}$ radio for 10 trials:

\begin{tabular}{|c|c|r|r|r|r|r|r|r|r|r|r|}
\cline { 2 - 13 } \multicolumn{1}{c|}{} & \multicolumn{10}{c|}{ Current Monitor Digital Output via Microcontroller (V) in Digital } \\
\hline $\begin{array}{c}\text { Vout } \\
\text { (V) }\end{array}$ & $\begin{array}{c}\text { Resistor } \\
\text { (digital) }\end{array}$ & $\begin{array}{c}\text { Trial } \\
\mathbf{1}\end{array}$ & $\begin{array}{c}\text { Trial } \\
\mathbf{2}\end{array}$ & $\begin{array}{c}\text { Trial } \\
\mathbf{3}\end{array}$ & $\begin{array}{c}\text { Trial } \\
\mathbf{4}\end{array}$ & $\begin{array}{c}\text { Trial } \\
\mathbf{5}\end{array}$ & $\begin{array}{c}\text { Trial } \\
\mathbf{6}\end{array}$ & $\begin{array}{c}\text { Trial } \\
\mathbf{7}\end{array}$ & $\begin{array}{c}\text { Trial } \\
\mathbf{8}\end{array}$ & $\begin{array}{c}\text { Trial } \\
\mathbf{9}\end{array}$ & $\begin{array}{c}\text { Trial } \\
\mathbf{1 0}\end{array}$ \\
\hline $\mathbf{6 . 1 1}$ & $\mathbf{1 8}$ & 3 & 3 & 3 & 2 & 3 & 4 & 3 & 3 & 4 & 3 \\
\hline $\mathbf{6 . 3 7 6}$ & $\mathbf{1 7}$ & 3 & 3 & 4 & 3 & 3 & 3 & 3 & 3 & 3 & 4 \\
\hline $\mathbf{6 . 7 4}$ & $\mathbf{1 6}$ & 5 & 10 & 6 & 5 & 13 & 4 & 10 & 9 & 9 & 7 \\
\hline $\mathbf{7 . 1 2}$ & $\mathbf{1 5}$ & 9 & 6 & 6 & 5 & 8 & 5 & 4 & 7 & 4 & 6 \\
\hline $\mathbf{7 . 5 5}$ & $\mathbf{1 4}$ & 6 & 6 & 14 & 7 & 6 & 6 & 10 & 9 & 5 & 5 \\
\hline $\mathbf{8 . 0 2}$ & $\mathbf{1 3}$ & 14 & 15 & 14 & 14 & 14 & 14 & 13 & 15 & 13 & 14 \\
\hline $\mathbf{8 . 5 9}$ & $\mathbf{1 2}$ & 15 & 14 & 14 & 14 & 15 & 15 & 14 & 15 & 14 & 15 \\
\hline $\mathbf{9 . 2 2}$ & $\mathbf{1 1}$ & 14 & 15 & 15 & 16 & 14 & 15 & 14 & 14 & 15 & 14 \\
\hline $\mathbf{1 0 . 0 1}$ & $\mathbf{1 0}$ & 14 & 15 & 16 & 16 & 16 & 15 & 14 & 14 & 15 & 15 \\
\hline $\mathbf{1 0 . 9 5}$ & $\mathbf{9}$ & 16 & 15 & 16 & 16 & 17 & 15 & 15 & 17 & 16 & 16 \\
\hline $\mathbf{1 2 . 1 2}$ & $\mathbf{8}$ & 16 & 15 & 17 & 16 & 17 & 16 & 16 & 17 & 16 & 15 \\
\hline
\end{tabular}

Table 4-14: Current monitor digital output for $9 \mathrm{~V}$ radio for 10 trials:

\begin{tabular}{|c|c|c|c|c|c|c|c|c|c|c|c|}
\hline & & Cur & ent $M$ & nitor I & igital ( & utput & ia Mic & rocont & oller ( & ) in D & gital \\
\hline $\begin{array}{l}\text { Vout } \\
\text { (V) }\end{array}$ & $\begin{array}{l}\text { Resistor } \\
\text { (digital) }\end{array}$ & $\begin{array}{c}\text { Trial } \\
1 \\
\end{array}$ & $\begin{array}{c}\text { Trial } \\
2 \\
\end{array}$ & $\begin{array}{c}\text { Trial } \\
3 \\
\end{array}$ & $\begin{array}{c}\text { Trial } \\
4 \\
\end{array}$ & $\begin{array}{c}\text { Trial } \\
5 \\
\end{array}$ & $\begin{array}{c}\text { Trial } \\
6 \\
\end{array}$ & $\begin{array}{c}\text { Trial } \\
7 \\
\end{array}$ & $\begin{array}{c}\text { Trial } \\
\mathbf{8} \\
\end{array}$ & $\begin{array}{c}\text { Trial } \\
9 \\
\end{array}$ & $\begin{array}{c}\text { Trial } \\
\mathbf{1 0} \\
\end{array}$ \\
\hline 6.11 & 18 & 3 & 3 & 3 & 3 & 3 & 3 & 3 & 3 & 3 & 3 \\
\hline 6.37 & 17 & 3 & 4 & 3 & 3 & 2 & 4 & 2 & 3 & 3 & 3 \\
\hline 6.74 & 16 & 4 & 11 & 4 & 12 & 6 & 4 & 4 & 7 & 6 & 4 \\
\hline 7.12 & 15 & 7 & 4 & 5 & 11 & 11 & 7 & 5 & 6 & 6 & 5 \\
\hline 7.55 & 14 & 22 & 15 & 8 & 5 & 4 & 12 & 12 & 13 & 12 & 12 \\
\hline 8.02 & 13 & 17 & 15 & 8 & 13 & 2 & 16 & 13 & 14 & 14 & 13 \\
\hline 8.59 & 12 & 14 & 13 & 14 & 13 & 14 & 13 & 14 & 13 & 14 & 13 \\
\hline 9.22 & 11 & 13 & 14 & 13 & 14 & 13 & 14 & 13 & 14 & 13 & 14 \\
\hline
\end{tabular}


Table 4-15: Current monitor digital output for $6 \mathrm{~V}$ TV for 10 trials:

\begin{tabular}{|c|c|c|c|c|c|c|c|r|r|r|r|}
\cline { 3 - 14 } & \multicolumn{10}{|c|}{ Current Monitor Digital Output via Microcontroller (V) in Digital } \\
\hline $\begin{array}{c}\text { Vout } \\
(\mathbf{V})\end{array}$ & $\begin{array}{c}\text { Resistor } \\
\text { (digital) }\end{array}$ & $\begin{array}{c}\text { Trial } \\
\mathbf{1}\end{array}$ & $\begin{array}{c}\text { Trial } \\
\mathbf{2}\end{array}$ & $\begin{array}{c}\text { Trial } \\
\mathbf{3}\end{array}$ & $\begin{array}{c}\text { Trial } \\
\mathbf{4}\end{array}$ & $\begin{array}{c}\text { Trial } \\
\mathbf{5}\end{array}$ & $\begin{array}{c}\text { Trial } \\
\mathbf{6}\end{array}$ & $\begin{array}{c}\text { Trial } \\
\mathbf{7}\end{array}$ & $\begin{array}{c}\text { Trial } \\
\mathbf{8}\end{array}$ & $\begin{array}{c}\text { Trial } \\
\mathbf{9}\end{array}$ & $\begin{array}{c}\text { Trial } \\
\mathbf{1 0}\end{array}$ \\
\hline $\mathbf{1 . 2}$ & $\mathbf{2 5 0}$ & 7 & 5 & 5 & 5 & 8 & 6 & 8 & 5 & 4 & 6 \\
\hline $\mathbf{1 . 4 6 5}$ & $\mathbf{1 5 0}$ & 12 & 15 & 6 & 6 & 8 & 12 & 12 & 14 & 9 & 10 \\
\hline $\mathbf{1 . 9 1}$ & $\mathbf{8 5}$ & 14 & 12 & 10 & 11 & 12 & 12 & 13 & 18 & 16 & 13 \\
\hline $\mathbf{2}$ & $\mathbf{7 0}$ & 21 & 21 & 21 & 22 & 22 & 23 & 22 & 21 & 21 & 21 \\
\hline $\mathbf{2 . 2}$ & $\mathbf{6 0}$ & 23 & 22 & 23 & 23 & 23 & 23 & 22 & 23 & 24 & 23 \\
\hline $\mathbf{2 . 7 6}$ & $\mathbf{5 0}$ & 25 & 25 & 26 & 24 & 24 & 25 & 19 & 24 & 26 & 25 \\
\hline $\mathbf{3 . 2 4}$ & $\mathbf{4 0}$ & 26 & 27 & 26 & 26 & 26 & 25 & 26 & 26 & 28 & 27 \\
\hline $\mathbf{4 . 0 3}$ & $\mathbf{3 0}$ & 27 & 27 & 28 & 28 & 28 & 27 & 27 & 27 & 27 & 28 \\
\hline $\mathbf{4 . 5 1}$ & $\mathbf{2 6}$ & 27 & 27 & 27 & 27 & 27 & 27 & 27 & 28 & 27 & 28 \\
\hline $\mathbf{5 . 2 2}$ & $\mathbf{2 3}$ & 29 & 28 & 28 & 29 & 27 & 28 & 28 & 29 & 27 & 27 \\
\hline $\mathbf{5 . 8}$ & $\mathbf{2 0}$ & 28 & 28 & 28 & 28 & 29 & 28 & 28 & 28 & 28 & 29 \\
\hline $\mathbf{6 . 5}$ & $\mathbf{1 8}$ & 28 & 29 & 28 & 29 & 29 & 28 & 29 & 29 & 28 & 28 \\
\hline
\end{tabular}

The static threshold design was applied to the microcontroller code and Table 4-16 shows sample results when the converter attempts to find each appliance's input voltage rating. Five trials are performed to prove that the algorithm is stable. In Table 4-17, the counter variable counts 6 times that the current is stable, but it is not equal or greater than 8 . This means that the converter will increase its output voltage until the current monitor counter sees a count equal or greater than 8 . Table 4-19 shows that there are 10 counts of $\Delta \mathrm{I}_{\mathrm{o}}$, which means stable current.

Table 4-16: Example of when 9V Radio does not meet its voltage ratings

\begin{tabular}{|c|c|c|c|c|c|r|r|r|r|r|r|}
\cline { 2 - 12 } \multicolumn{1}{|c}{} & \multicolumn{10}{|c|}{ Current Monitor Digital Output via Microcontroller (V) in Digital } \\
\hline $\begin{array}{c}\text { Vout } \\
\text { (V) }\end{array}$ & $\begin{array}{c}\text { Resistor } \\
\text { (digital) }\end{array}$ & $\begin{array}{c}\text { Trial } \\
\mathbf{1}\end{array}$ & $\begin{array}{c}\text { Trial } \\
\mathbf{2}\end{array}$ & $\begin{array}{c}\text { Trial } \\
\mathbf{3}\end{array}$ & $\begin{array}{c}\text { Trial } \\
\mathbf{4}\end{array}$ & $\begin{array}{c}\text { Trial } \\
\mathbf{5}\end{array}$ & $\begin{array}{c}\text { Trial } \\
\mathbf{6}\end{array}$ & $\begin{array}{c}\text { Trial } \\
\mathbf{7}\end{array}$ & $\begin{array}{c}\text { Trial } \\
\mathbf{8}\end{array}$ & $\begin{array}{c}\text { Trial } \\
\mathbf{9}\end{array}$ & $\begin{array}{c}\text { Trial } \\
\mathbf{1 0}\end{array}$ \\
\hline $\mathbf{6 . 7 4}$ & $\mathbf{1 6}$ & 4 & 11 & 4 & 12 & 6 & 4 & 4 & 7 & 6 & 4 \\
\hline $\mathbf{7 . 1 2}$ & $\mathbf{1 5}$ & 7 & 4 & 5 & 11 & 11 & 7 & 5 & 6 & 6 & 5 \\
\hline
\end{tabular}

Table 4-17: Difference in current monitor voltages between 6.74V and 7.12V

\begin{tabular}{|l|l|l|r|r|r|r|r|r|r|}
\hline \multicolumn{10}{|c|}{$\Delta \mathbf{I}_{\mathbf{0}}$ (in digital voltage form) } \\
\hline-3 & 7 & -1 & 1 & -5 & -3 & -1 & 1 & 0 & -1 \\
\hline
\end{tabular}


Table 4-18: Example of when 9V Radio does meets its voltage ratings

\begin{tabular}{|c|c|c|c|c|c|c|c|c|c|c|c|}
\hline & & & & & & & & & er & 10 & ital \\
\hline $\begin{array}{l}\text { Vout } \\
\text { (V) }\end{array}$ & $\begin{array}{l}\text { Resistor } \\
\text { (digital) }\end{array}$ & $\begin{array}{c}\text { Trial } \\
1\end{array}$ & $\begin{array}{c}\text { Trial } \\
2 \\
\end{array}$ & $\begin{array}{c}\text { Trial } \\
\mathbf{3} \\
\end{array}$ & $\begin{array}{c}\text { Trial } \\
4 \\
\end{array}$ & $\begin{array}{c}\text { Trial } \\
5\end{array}$ & $\begin{array}{c}\text { Trial } \\
6\end{array}$ & $\begin{array}{c}\text { Trial } \\
7 \\
\end{array}$ & $\begin{array}{c}\text { Trial } \\
8 \\
\end{array}$ & $\begin{array}{c}\text { Trial } \\
9\end{array}$ & $\begin{array}{c}\text { Trial } \\
10 \\
\end{array}$ \\
\hline 8.59 & 12 & 14 & 13 & 14 & 13 & 14 & 13 & 14 & 13 & 14 & 13 \\
\hline 9.22 & 11 & 13 & 14 & 13 & 14 & 13 & 14 & 13 & 14 & 13 & 14 \\
\hline
\end{tabular}

Table 4-19: Difference in current monitor voltages between $8.59 \mathrm{~V}$ and $9.22 \mathrm{~V}$

\begin{tabular}{|l|r|r|r|r|r|r|r|r|r|}
\hline \multicolumn{10}{|c|}{$\Delta \mathbf{I}_{\mathbf{0}}$ (in digital voltage form) } \\
\hline 1 & -1 & 1 & -1 & 1 & -1 & 1 & -1 & 1 & -1 \\
\hline
\end{tabular}

Table 4-20: Wall Plug Voltages for the $12 \mathrm{~V}$ radio, $9 \mathrm{~V}$ radio, and $6 \mathrm{~V}$ TV results

\begin{tabular}{|c|c|c|c|c|c|}
\hline $\begin{array}{c}\text { 12V } \\
\text { Radio }\end{array}$ & $\begin{array}{c}\text { Output } \\
\text { Voltage } \\
\text { (V) }\end{array}$ & $\begin{array}{c}\text { 9V } \\
\text { Radio }\end{array}$ & $\begin{array}{c}\text { Output } \\
\text { Voltage } \\
\text { (V) }\end{array}$ & 6V TV & $\begin{array}{c}\text { Output } \\
\text { Voltage } \\
\text { (V) }\end{array}$ \\
\hline Trial 1 & 8.59 & Trial 1 & 9.22 & Trial 1 & 1.8 \\
\hline Trial 2 & 8.02 & Trial 2 & 9.22 & Trial 2 & 1.8 \\
\hline Trial 3 & 8.59 & Trial 3 & 9.22 & Trial 3 & 2 \\
\hline Trial 4 & 8.02 & Trial 4 & 9.22 & Trial 4 & 1.8 \\
\hline Trial 5 & 8.59 & Trial 5 & 9.22 & Trial 5 & 1.8 \\
\hline
\end{tabular}

The final output voltage for each appliance is not accurate as expected shown in Table 420. For the $12 \mathrm{~V}$ radio, trial 2 and trial 4 has output voltages of $8.02 \mathrm{~V}$, where trial 1,3 , and 5 has output voltages of $8.59 \mathrm{~V}$. There are two concerns: the final output voltages are not constant and although it finds the minimum input voltage rating it is still not close to $12 \mathrm{~V}$. For the $9 \mathrm{~V}$ radio, the static threshold holds valid because the output voltage meets the voltage rating and the trial voltages are constant. As for the $6 \mathrm{~V} \mathrm{TV}$, the output voltages of $1.8 \mathrm{~V}$ and $2 \mathrm{~V}$ do not meet the $6 \mathrm{~V}$ requirement. As an attempt to improve this, an additional algorithm is inserted to the code.

The purpose of the accuracy algorithm (Method \#4) is to provide a closer output voltage to the nominal voltage rating of each load. As in Method \#3, the microcontroller samples only the chosen output voltage (e.g. 4.03V) in 10 trials for three rounds as shown in Table 4-21. Then 
the microcontroller samples the previous output voltage (e.g. 3.24V) in 10 trials for three rounds as well. The $\Delta \mathrm{I}_{\mathrm{o}}$ method takes the difference of digital voltages in Table 4-21 and Table 4-22 and outputs the difference in voltages in Table 4-23. Then Table 4-24 shows the total of $\Delta \mathrm{I}$ for each round. Note that the difference between the digital voltages is its absolute value for summing purposes. The average column is the average of the total number divided by 10 . Finally, the averages are compared, and the smallest average number will determine if the final converter voltage will increase or decrease in Table 4-24. The smallest average value is being used to make the decision because ideally stable current means the appliance has reached its rated voltage and no fluctuating current values exist. In the case listed under Table 4-24, the smallest average value is 0.5 .

Next, the microcontroller then increases the voltage by one digital potentiometer step (e.g. $4.51 \mathrm{~V}$ ) and samples its output voltages in 10 trials for three rounds again as shown in Tables 4-25 and 4-26. The $\Delta \mathrm{I}_{\mathrm{o}}$ method kicks in and takes the difference of those values in Table 4-25 (4.03V) and Table 4-26 (4.51V). The following Table 4-27 shows the total of $\Delta \mathrm{I}_{\mathrm{o}}$ for each round. The average column is the average of the total number divided by 10 . Finally, the averages are compared and the smallest average number will determine if the final converter voltage will increase or decrease as shown in Table 4-28. In this case, the smallest average is 0.4.

Finally, both smallest averages are compared. The smallest average will determine if the output voltage should stay at the same voltage of $4.03 \mathrm{~V}$, or to increase to $4.51 \mathrm{~V}$. Since the smallest average is 0.4 according to Table $4-29$, the voltage will increase. Otherwise, if the smallest average occurred at the $4.03 \mathrm{~V}$ and $3.24 \mathrm{~V}$ comparison, then the voltage will be kept the same at $4.03 \mathrm{~V}$. 
Table 4-21: Current Monitor Readings for Chosen Output Voltage (4.03V) for 6 V TV

\begin{tabular}{|c|c|c|c|c|c|c|c|c|c|c|}
\cline { 2 - 11 } \multicolumn{1}{c|}{} & \multicolumn{6}{c|}{ Current Monitor Digital Output via Microcontroller (V) in Digital } \\
\cline { 2 - 11 } & $\begin{array}{c}\text { Trial } \\
\mathbf{1}\end{array}$ & $\begin{array}{c}\text { Trial } \\
\mathbf{2}\end{array}$ & $\begin{array}{c}\text { Trial } \\
\mathbf{3}\end{array}$ & $\begin{array}{c}\text { Trial } \\
\mathbf{4}\end{array}$ & $\begin{array}{c}\text { Trial } \\
\mathbf{5}\end{array}$ & $\begin{array}{c}\text { Trial } \\
\mathbf{6}\end{array}$ & $\begin{array}{c}\text { Trial } \\
\mathbf{7}\end{array}$ & $\begin{array}{c}\text { Trial } \\
\mathbf{8}\end{array}$ & $\begin{array}{c}\text { Trial } \\
\mathbf{9}\end{array}$ & $\begin{array}{c}\text { Trial } \\
\mathbf{1 0}\end{array}$ \\
\hline $\begin{array}{c}\text { Round } \\
\mathbf{1}\end{array}$ & 27 & 27 & 27 & 27 & 27 & 27 & 27 & 28 & 27 & 28 \\
\hline $\begin{array}{c}\text { Round } \\
\mathbf{2}\end{array}$ & 28 & 27 & 26 & 27 & 27 & 28 & 28 & 29 & 27 & 27 \\
\hline $\begin{array}{c}\text { Round } \\
\mathbf{3}\end{array}$ & 28 & 28 & 28 & 28 & 29 & 28 & 28 & 27 & 28 & 29 \\
\hline
\end{tabular}

Table 4-22: Current Monitor Readings for Decreased Output Voltage (3.24V) for 6V TV

\begin{tabular}{|c|c|c|c|c|c|c|c|c|c|c|}
\cline { 2 - 11 } \multicolumn{1}{c|}{} & \multicolumn{6}{|c}{ Current Monitor Digital Output via Microcontroller (V) in Digital } \\
\cline { 2 - 11 } & Trial & Trial & Trial & Trial & Trial & Trial & Trial & Trial & $\begin{array}{c}\text { Trial } \\
\mathbf{2}\end{array}$ & $\begin{array}{c}\text { Trial } \\
\mathbf{1 0}\end{array}$ \\
\hline $\begin{array}{c}\text { Round } \\
\mathbf{1}\end{array}$ & 27 & 28 & 27 & 26 & 28 & 27 & 27 & 26 & 27 & 28 \\
\hline $\begin{array}{c}\text { Round } \\
\mathbf{2}\end{array}$ & 28 & 28 & 28 & 27 & 27 & 27 & 28 & 27 & 26 & 26 \\
\hline $\begin{array}{c}\text { Round } \\
\mathbf{3}\end{array}$ & 28 & 27 & 27 & 27 & 26 & 27 & 26 & 28 & 26 & 28 \\
\hline
\end{tabular}

Table 4-23: Current Monitor Differences (Results) from Table 4-20 and Table 4-21 for 6V TV

\begin{tabular}{|c|c|c|c|c|c|c|c|c|c|c|}
\cline { 2 - 11 } \multicolumn{1}{c|}{} & \multicolumn{10}{c|}{ Current Monitor Digital Output via Microcontroller $\left(\Delta \mathbf{I}_{\mathbf{0}}\right)$ in Digital } \\
\cline { 2 - 11 } & $\begin{array}{c}\text { Trial } \\
\mathbf{1}\end{array}$ & $\begin{array}{c}\text { Trial } \\
\mathbf{2}\end{array}$ & $\begin{array}{c}\text { Trial } \\
\mathbf{3}\end{array}$ & $\begin{array}{c}\text { Trial } \\
\mathbf{4}\end{array}$ & $\begin{array}{c}\text { Trial } \\
\mathbf{5}\end{array}$ & $\begin{array}{c}\text { Trial } \\
\mathbf{6}\end{array}$ & $\begin{array}{c}\text { Trial } \\
\mathbf{7}\end{array}$ & $\begin{array}{c}\text { Trial } \\
\mathbf{8}\end{array}$ & $\begin{array}{c}\text { Trial } \\
\mathbf{9}\end{array}$ & $\begin{array}{c}\text { Trial } \\
\mathbf{1 0}\end{array}$ \\
\hline $\begin{array}{c}\text { Round } \\
\mathbf{1}\end{array}$ & 0 & 1 & 0 & 1 & 1 & 0 & 0 & 2 & 0 & 0 \\
\hline $\begin{array}{c}\text { Round } \\
\mathbf{2}\end{array}$ & 0 & 1 & 2 & 0 & 0 & 1 & 0 & 2 & 1 & 1 \\
\hline $\begin{array}{c}\text { Round } \\
\mathbf{3}\end{array}$ & 0 & 1 & 1 & 1 & 3 & 1 & 2 & 1 & 2 & 1 \\
\hline
\end{tabular}


Table 4-24: Mathematical Results from Table 4-22 to obtain the lowest number

\begin{tabular}{|c|c|c|}
\hline Total & Average & $\begin{array}{c}\text { Lowest } \\
\text { Number }\end{array}$ \\
\cline { 1 - 2 } 5 & 0.5 & \multirow{2}{*}{0.5} \\
\cline { 1 - 2 } 8 & 0.8 & \multirow{2}{*}{0.5} \\
\hline 13 & 1.3 & \\
\hline
\end{tabular}

Table 4-25: Current Monitor Readings for Chosen Output Voltage (4.03V) for 6V TV

\begin{tabular}{|c|c|c|c|c|c|c|c|c|c|c|}
\cline { 2 - 11 } \multicolumn{1}{c|}{} & \multicolumn{1}{c|}{ Current Monitor Digital Output via Microcontroller (V) in Digital } \\
\cline { 2 - 11 } & $\begin{array}{c}\text { Trial } \\
\mathbf{1}\end{array}$ & $\begin{array}{c}\text { Trial } \\
\mathbf{2}\end{array}$ & $\begin{array}{c}\text { Trial } \\
\mathbf{3}\end{array}$ & $\begin{array}{c}\text { Trial } \\
\mathbf{4}\end{array}$ & $\begin{array}{c}\text { Trial } \\
\mathbf{5}\end{array}$ & $\begin{array}{c}\text { Trial } \\
\mathbf{6}\end{array}$ & $\begin{array}{c}\text { Trial } \\
\mathbf{7}\end{array}$ & $\begin{array}{c}\text { Trial } \\
\mathbf{8}\end{array}$ & $\begin{array}{c}\text { Trial } \\
\mathbf{9}\end{array}$ & $\begin{array}{c}\text { Trial } \\
\mathbf{1 0}\end{array}$ \\
\hline $\begin{array}{c}\text { Round } \\
\mathbf{1}\end{array}$ & 27 & 27 & 27 & 27 & 27 & 27 & 27 & 28 & 27 & 28 \\
\hline $\begin{array}{c}\text { Round } \\
\mathbf{2}\end{array}$ & 28 & 27 & 26 & 27 & 27 & 28 & 28 & 29 & 27 & 27 \\
\hline $\begin{array}{c}\text { Round } \\
\mathbf{3}\end{array}$ & 28 & 28 & 28 & 28 & 29 & 28 & 28 & 27 & 28 & 29 \\
\hline
\end{tabular}

Table 4-26: Current Monitor Readings for Decreased Output Voltage (4.51V) for 6V TV

\begin{tabular}{|c|c|c|c|c|c|c|c|c|c|c|}
\cline { 2 - 11 } \multicolumn{1}{c|}{} & \multicolumn{1}{c|}{ Current Monitor Digital Output via Microcontroller (V) in Digital } \\
\cline { 2 - 11 } & $\begin{array}{c}\text { Trial } \\
\mathbf{1}\end{array}$ & $\begin{array}{c}\text { Trial } \\
\mathbf{2}\end{array}$ & $\begin{array}{c}\text { Trial } \\
\mathbf{3}\end{array}$ & $\begin{array}{c}\text { Trial } \\
\mathbf{4}\end{array}$ & $\begin{array}{c}\text { Trial } \\
\mathbf{5}\end{array}$ & $\begin{array}{c}\text { Trial } \\
\mathbf{6}\end{array}$ & $\begin{array}{c}\text { Trial } \\
\mathbf{7}\end{array}$ & $\begin{array}{c}\text { Trial } \\
\mathbf{8}\end{array}$ & $\begin{array}{c}\text { Trial } \\
\mathbf{9}\end{array}$ & $\begin{array}{c}\text { Trial } \\
\mathbf{1 0}\end{array}$ \\
\hline $\begin{array}{c}\text { Round } \\
\mathbf{1}\end{array}$ & 27 & 27 & 27 & 26 & 27 & 27 & 27 & 26 & 27 & 27 \\
\hline $\begin{array}{c}\text { Round } \\
\mathbf{2}\end{array}$ & 26 & 27 & 27 & 27 & 28 & 27 & 27 & 29 & 27 & 27 \\
\hline $\begin{array}{c}\text { Round } \\
\mathbf{3}\end{array}$ & 28 & 28 & 28 & 28 & 27 & 27 & 27 & 28 & 27 & 28 \\
\hline
\end{tabular}

Table 4-27: Current Monitor Differences (Results) from Table 4-24 and Table 4-25 for 6V TV 


\begin{tabular}{|c|c|c|c|c|c|c|c|c|c|c|}
\cline { 2 - 11 } \multicolumn{1}{c|}{} & \multicolumn{6}{c|}{ Current Monitor Digital Output via Microcontroller $\left(\Delta \mathbf{I}_{\mathbf{0}}\right)$ in Digital } \\
\cline { 2 - 11 } & $\begin{array}{c}\text { Trial } \\
\mathbf{1}\end{array}$ & $\begin{array}{c}\text { Trial } \\
\mathbf{2}\end{array}$ & $\begin{array}{c}\text { Trial } \\
\mathbf{3}\end{array}$ & $\begin{array}{c}\text { Trial } \\
\mathbf{4}\end{array}$ & $\begin{array}{c}\text { Trial } \\
\mathbf{5}\end{array}$ & $\begin{array}{c}\text { Trial } \\
\mathbf{6}\end{array}$ & $\begin{array}{c}\text { Trial } \\
\mathbf{7}\end{array}$ & $\begin{array}{c}\text { Trial } \\
\mathbf{8}\end{array}$ & $\begin{array}{c}\text { Trial } \\
\mathbf{9}\end{array}$ & $\begin{array}{c}\text { Trial } \\
\mathbf{1 0}\end{array}$ \\
\hline $\begin{array}{c}\text { Round } \\
\mathbf{1}\end{array}$ & 0 & 0 & 0 & 1 & 0 & 0 & 0 & 2 & 0 & 1 \\
\hline $\begin{array}{c}\text { Round } \\
\mathbf{2}\end{array}$ & 2 & 0 & 1 & 0 & 1 & 1 & 1 & 0 & 0 & 0 \\
\hline $\begin{array}{c}\text { Round } \\
\mathbf{3}\end{array}$ & 0 & 0 & 0 & 0 & 2 & 1 & 1 & 1 & 1 & 1 \\
\hline
\end{tabular}

Table 4-28: Mathematical Results from Table 4-26 to obtain the lowest number

\begin{tabular}{|c|c|c|}
\hline Total & Average & $\begin{array}{c}\text { Lowest } \\
\text { Number }\end{array}$ \\
\hline 4 & 0.4 & \multirow{2}{*}{0.4} \\
\cline { 1 - 2 } 6 & 0.6 & \\
\hline 7 & 0.7 & \\
\hline
\end{tabular}

Table 4-29: Lowest number comparison for two different voltages

\begin{tabular}{|c|c|}
\hline $\begin{array}{c}\text { Lowest } \\
\text { Number for }\end{array}$ & Lowest \\
Number for \\
4.03V \& 3.24V & $\mathbf{4 . 0 3 V ~ \& ~ 4 . 5 1 V ~}$ \\
(Case 1) & (Case 2) \\
\hline 0.5 & 0.4 \\
\hline
\end{tabular}

For testing purposes, five trials are conducted using the accuracy algorithm method for the $12 \mathrm{~V}$ radio, $9 \mathrm{~V}$ radio, and $6 \mathrm{~V}$ TV. For Tables 4-30 to 4-44, measured results do not match up with the expected results. For example, with the $12 \mathrm{~V}$ radio, since the chosen output voltage was at $8.59 \mathrm{~V} / 8.02 \mathrm{~V}$, it would be expected that the algorithm would increase the voltage to meet the $12 \mathrm{~V}$ requirement and $\Delta \mathrm{I}_{\mathrm{o}}$ would be less as the voltage gets closer to its rated voltage. Also, for the $9 \mathrm{~V}$ radio, the algorithm increases the output voltage to $10 \mathrm{~V}$ in a total of 4 overall trials, which exceeds the $9 \mathrm{~V}$ requirement. For the $6 \mathrm{~V}$ TV, the algorithm keeps the output voltage constant at $2.2 \mathrm{~V}-2.5 \mathrm{~V}$, when it would be expected that the output voltage would increase since it 
is below its rated voltage. Overall, adding the accuracy algorithm did not seem to produce significant improvement in acquiring more accurate output voltage. One way to achieve better results with the accuracy algorithm is perhaps to add more trials (more than 3 ) to finding the $\Delta \mathrm{I}_{0}$. This may, however, poses concern due to increased code complexity when comparing more than 3 average numbers, and more response time delay of the wall plug.

Table 4-30: Previous and Next Voltage Comparisons for 3 Iterations for the 12V Radio (Trial 1)

\begin{tabular}{|c|c|c|c|}
\hline \multicolumn{4}{|c|}{ Trial 1 } \\
\hline $\begin{array}{c}\text { Previous Voltage } \\
\text { Comparison (Iteration 1) }\end{array}$ & $\begin{array}{c}\text { Previous Voltage } \\
\text { Comparison (Iteration 2) }\end{array}$ & $\begin{array}{c}\text { Previous Voltage } \\
\text { Comparison (Iteration 3) }\end{array}$ & $\begin{array}{c}\text { Lowest } \\
\text { Number }\end{array}$ \\
\hline 1 & 0.7 & 0.9 & 0.7 \\
\hline $\begin{array}{c}\text { Next Voltage } \\
\text { Comparison (Iteration 1) }\end{array}$ & $\begin{array}{c}\text { Next Voltage } \\
\text { Comparison (Iteration 2) }\end{array}$ & $\begin{array}{c}\text { Next Voltage Comparison } \\
\text { (Iteration 3) }\end{array}$ & $\begin{array}{c}\text { Lowest } \\
\text { Number }\end{array}$ \\
\hline 1 & 1 & 1.2 & 1 \\
\hline \multicolumn{4}{|c|}{ Result: Voltage stays at 9.2V } \\
\hline
\end{tabular}

Table 4-31: Previous and Next Voltage Comparisons for 3 Iterations for the 12V Radio (Trial 2)

\begin{tabular}{|c|c|c|c|}
\hline \multicolumn{4}{|c|}{ Trial 2 } \\
\hline $\begin{array}{c}\text { Previous Voltage } \\
\text { Comparison (Iteration 1) }\end{array}$ & $\begin{array}{c}\text { Previous Voltage } \\
\text { Comparison (Iteration 2) }\end{array}$ & $\begin{array}{c}\text { Previous Voltage } \\
\text { Comparison (Iteration 3) }\end{array}$ & $\begin{array}{c}\text { Lowest } \\
\text { Number }\end{array}$ \\
\hline 0.8 & 0.9 & 0.6 & 0.6 \\
\hline $\begin{array}{c}\text { Next Voltage } \\
\text { Comparison (Iteration 1) }\end{array}$ & $\begin{array}{c}\text { Next Voltage } \\
\text { Comparison (Iteration 2) }\end{array}$ & $\begin{array}{c}\text { Next Voltage Comparison } \\
\text { (Iteration 3) }\end{array}$ & $\begin{array}{c}\text { Lowest } \\
\text { Number }\end{array}$ \\
\hline 0.9 & 0.9 & 0.6 & 0.6 \\
\hline \multicolumn{4}{|c|}{ Result: Voltage Increases to 10V } \\
\hline
\end{tabular}

Table 4-32: Previous and Next Voltage Comparisons for 3 Iterations for the 12V Radio (Trial 3) 


\begin{tabular}{|c|c|c|c|}
\hline \multicolumn{4}{|c|}{ Trial 3 } \\
\hline $\begin{array}{c}\text { Previous Voltage } \\
\text { Comparison (Iteration 1) }\end{array}$ & $\begin{array}{c}\text { Previous Voltage } \\
\text { Comparison (Iteration 2) }\end{array}$ & $\begin{array}{c}\text { Previous Voltage } \\
\text { Comparison (Iteration 3) }\end{array}$ & $\begin{array}{c}\text { Lowest } \\
\text { Number }\end{array}$ \\
\hline 2 & 0.9 & 3 & 0.9 \\
\hline $\begin{array}{c}\text { Next Voltage } \\
\text { Comparison (Iteration 1) }\end{array}$ & $\begin{array}{c}\text { Next Voltage } \\
\text { Comparison (Iteration 2) }\end{array}$ & $\begin{array}{c}\text { Next Voltage Comparison } \\
\text { (Iteration 3) }\end{array}$ & $\begin{array}{c}\text { Lowest } \\
\text { Number }\end{array}$ \\
\hline 1.4 & 1.1 & 1.8 & 1.1 \\
\hline \multicolumn{4}{|c|}{ Result: Voltage stays at 9.2V } \\
\hline
\end{tabular}

Table 4-33: Previous and Next Voltage Comparisons for 3 Iterations for the 12V Radio (Trial 4)

\begin{tabular}{|c|c|c|c|}
\hline \multicolumn{4}{|c|}{ Trial 4 } \\
\hline $\begin{array}{c}\text { Previous Voltage } \\
\text { Comparison (Iteration 1) }\end{array}$ & $\begin{array}{c}\text { Previous Voltage } \\
\text { Comparison (Iteration 2) }\end{array}$ & $\begin{array}{c}\text { Previous Voltage } \\
\text { Comparison (Iteration 3) }\end{array}$ & $\begin{array}{c}\text { Lowest } \\
\text { Number }\end{array}$ \\
\hline 0.6 & 0.7 & 0.5 & 0.5 \\
\hline $\begin{array}{c}\text { Next Voltage } \\
\text { Comparison (Iteration 1) }\end{array}$ & $\begin{array}{c}\text { Next Voltage } \\
\text { Comparison (Iteration 2) }\end{array}$ & $\begin{array}{c}\text { Next Voltage Comparison } \\
\text { (Iteration 3) }\end{array}$ & $\begin{array}{c}\text { Lowest } \\
\text { Number }\end{array}$ \\
\hline 1.3 & 1.6 & 0.9 & 0.9 \\
\hline \multicolumn{4}{|c|}{ Result: Voltage stays at 9.2V } \\
\hline
\end{tabular}

Table 4-34: Previous and Next Voltage Comparisons for 3 Iterations for the 12V Radio (Trial 5)

\begin{tabular}{|c|c|c|c|}
\hline \multicolumn{4}{|c|}{ Trial 5 } \\
\hline $\begin{array}{c}\text { Previous Voltage } \\
\text { Comparison (Iteration 1) }\end{array}$ & $\begin{array}{c}\text { Previous Voltage } \\
\text { Comparison (Iteration 2) }\end{array}$ & $\begin{array}{c}\text { Previous Voltage } \\
\text { Comparison (Iteration 3) }\end{array}$ & $\begin{array}{c}\text { Lowest } \\
\text { Number }\end{array}$ \\
\hline 0.5 & 0.7 & 0.9 & 0.5 \\
\hline $\begin{array}{c}\text { Next Voltage } \\
\text { Comparison (Iteration 1) }\end{array}$ & $\begin{array}{c}\text { Next Voltage } \\
\text { Comparison (Iteration 2) }\end{array}$ & $\begin{array}{c}\text { Next Voltage Comparison } \\
\text { (Iteration 3) }\end{array}$ & $\begin{array}{c}\text { Lowest } \\
\text { Number }\end{array}$ \\
\hline 1.5 & 1 & 0.9 & 0.9 \\
\hline \multicolumn{4}{|c|}{ Result: Voltage stays at 9.2V } \\
\hline
\end{tabular}

Table 4-35: Previous and Next Voltage Comparisons for 3 Iterations for the 9V Radio (Trial 1) 


\begin{tabular}{|c|c|c|c|}
\hline \multicolumn{4}{|c|}{ Trial 1 } \\
\hline $\begin{array}{c}\text { Previous Voltage } \\
\text { Comparison (Iteration 1) }\end{array}$ & $\begin{array}{c}\text { Previous Voltage } \\
\text { Comparison (Iteration 2) }\end{array}$ & $\begin{array}{c}\text { Previous Voltage } \\
\text { Comparison (Iteration 3) }\end{array}$ & $\begin{array}{c}\text { Lowest } \\
\text { Number }\end{array}$ \\
\hline 0.9 & 0.7 & 0.9 & 0.7 \\
\hline $\begin{array}{c}\text { Next Voltage } \\
\text { Comparison (Iteration 1) }\end{array}$ & $\begin{array}{c}\text { Next Voltage } \\
\text { Comparison (Iteration 2) }\end{array}$ & $\begin{array}{c}\text { Next Voltage Comparison } \\
\text { (Iteration 3) }\end{array}$ & $\begin{array}{c}\text { Lowest } \\
\text { Number }\end{array}$ \\
\hline 1.1 & 1.4 & 1.1 & 1.1 \\
\hline \multicolumn{4}{|c|}{ Result: Voltage stays at 9.2V } \\
\hline
\end{tabular}

Table 4-36: Previous and Next Voltage Comparisons for 3 Iterations for the $9 \mathrm{~V}$ Radio (Trial 2)

\begin{tabular}{|c|c|c|c|}
\hline \multicolumn{4}{|c|}{ Trial 2 } \\
\hline $\begin{array}{c}\text { Previous Voltage } \\
\text { Comparison (Iteration 1) }\end{array}$ & $\begin{array}{c}\text { Previous Voltage } \\
\text { Comparison (Iteration 2) }\end{array}$ & $\begin{array}{c}\text { Previous Voltage } \\
\text { Comparison (Iteration 3) }\end{array}$ & $\begin{array}{c}\text { Lowest } \\
\text { Number }\end{array}$ \\
\hline 1.5 & 1.2 & 2 & 1.2 \\
\hline $\begin{array}{c}\text { Next Voltage } \\
\text { Comparison (Iteration 1) }\end{array}$ & $\begin{array}{c}\text { Next Voltage } \\
\text { Comparison (Iteration 2) }\end{array}$ & $\begin{array}{c}\text { Next Voltage Comparison } \\
\text { (Iteration 3) }\end{array}$ & $\begin{array}{c}\text { Lowest } \\
\text { Number }\end{array}$ \\
\hline 1.1 & 0.5 & 1 & 0.5 \\
\hline \multicolumn{4}{|c|}{ Result: Voltage Increases to 10V } \\
\hline
\end{tabular}

Table 4-37: Previous and Next Voltage Comparisons for 3 Iterations for the 9V Radio (Trial 3)

\begin{tabular}{|c|c|c|c|}
\hline \multicolumn{4}{|c|}{ Trial 3 } \\
\hline $\begin{array}{c}\text { Previous Voltage } \\
\text { Comparison (Iteration 1) }\end{array}$ & $\begin{array}{c}\text { Previous Voltage } \\
\text { Comparison (Iteration 2) }\end{array}$ & $\begin{array}{c}\text { Previous Voltage } \\
\text { Comparison (Iteration 3) }\end{array}$ & $\begin{array}{c}\text { Lowest } \\
\text { Number }\end{array}$ \\
\hline 1.9 & 4.4 & 2.8 & 1.9 \\
\hline $\begin{array}{c}\text { Next Voltage } \\
\text { Comparison (Iteration 1) }\end{array}$ & $\begin{array}{c}\text { Next Voltage } \\
\text { Comparison (Iteration 2) }\end{array}$ & $\begin{array}{c}\text { Next Voltage Comparison } \\
\text { (Iteration 3) }\end{array}$ & $\begin{array}{c}\text { Lowest } \\
\text { Number }\end{array}$ \\
\hline 1.2 & 1.8 & 0.8 & 0.8 \\
\hline \multicolumn{4}{|c|}{ Result: Voltage Increases to 9.2V } \\
\hline
\end{tabular}

Table 4-38: Previous and Next Voltage Comparisons for 3 Iterations for the 9V Radio (Trial 4) 


\begin{tabular}{|c|c|c|c|}
\hline \multicolumn{4}{|c|}{ Trial 4 } \\
\hline $\begin{array}{c}\text { Previous Voltage } \\
\text { Comparison (Iteration 1) }\end{array}$ & $\begin{array}{c}\text { Previous Voltage } \\
\text { Comparison (Iteration 2) }\end{array}$ & $\begin{array}{c}\text { Previous Voltage } \\
\text { Comparison (Iteration 3) }\end{array}$ & $\begin{array}{c}\text { Lowest } \\
\text { Number }\end{array}$ \\
\hline 3.3 & 3.2 & 2.5 & 2.5 \\
\hline $\begin{array}{c}\text { Next Voltage } \\
\text { Comparison (Iteration 1) }\end{array}$ & $\begin{array}{c}\text { Next Voltage } \\
\text { Comparison (Iteration 2) }\end{array}$ & $\begin{array}{c}\text { Next Voltage Comparison } \\
\text { (Iteration 3) }\end{array}$ & $\begin{array}{c}\text { Lowest } \\
\text { Number }\end{array}$ \\
\hline 0.7 & 0.8 & 0.7 & 0.7 \\
\hline \multicolumn{4}{|c|}{ Result: Voltage Increases to 10V } \\
\hline
\end{tabular}

Table 4-39: Previous and Next Voltage Comparisons for 3 Iterations for the $9 \mathrm{~V}$ Radio (Trial 5)

\begin{tabular}{|c|c|c|c|}
\hline \multicolumn{4}{|c|}{ Trial 5 } \\
\hline $\begin{array}{c}\text { Previous Voltage } \\
\text { Comparison (Iteration 1) }\end{array}$ & $\begin{array}{c}\text { Previous Voltage } \\
\text { Comparison (Iteration 2) }\end{array}$ & $\begin{array}{c}\text { Previous Voltage } \\
\text { Comparison (Iteration 3) }\end{array}$ & $\begin{array}{c}\text { Lowest } \\
\text { Number }\end{array}$ \\
\hline 1 & 0.7 & 0.9 & 0.7 \\
\hline $\begin{array}{c}\text { Next Voltage } \\
\text { Comparison (Iteration 1) }\end{array}$ & $\begin{array}{c}\text { Next Voltage } \\
\text { Comparison (Iteration 2) }\end{array}$ & $\begin{array}{c}\text { Next Voltage Comparison } \\
\text { (Iteration 3) }\end{array}$ & $\begin{array}{c}\text { Lowest } \\
\text { Number }\end{array}$ \\
\hline 1 & 1 & 1.2 & 1 \\
\hline \multicolumn{4}{|c|}{ Result: Voltage Increases to 10V } \\
\hline
\end{tabular}

Table 4-40: Previous and Next Voltage Comparisons for 3 Iterations for the 6V TV (Trial 1)

\begin{tabular}{|c|c|c|c|}
\hline \multicolumn{4}{|c|}{ Trial 1 } \\
\hline $\begin{array}{c}\text { Previous Voltage } \\
\text { Comparison (Iteration 1) }\end{array}$ & $\begin{array}{c}\text { Previous Voltage } \\
\text { Comparison (Iteration 2) }\end{array}$ & $\begin{array}{c}\text { Previous Voltage } \\
\text { Comparison (Iteration 3) }\end{array}$ & $\begin{array}{c}\text { Lowest } \\
\text { Number }\end{array}$ \\
\hline 4.1 & 5.4 & 3.8 & 3.8 \\
\hline $\begin{array}{c}\text { Next Voltage } \\
\text { Comparison (Iteration 1) }\end{array}$ & $\begin{array}{c}\text { Next Voltage } \\
\text { Comparison (Iteration 2) }\end{array}$ & $\begin{array}{c}\text { Next Voltage Comparison } \\
\text { (Iteration 3) }\end{array}$ & $\begin{array}{c}\text { Lowest } \\
\text { Number }\end{array}$ \\
\hline 4.2 & 2.5 & 3.3 & 2.5 \\
\hline \multicolumn{4}{|c|}{ Result: Voltage Decreases to 2.2V } \\
\hline
\end{tabular}

Table 4-41: Previous and Next Voltage Comparisons for 3 Iterations for the 6V TV (Trial 2) 


\begin{tabular}{|c|c|c|c|}
\hline \multicolumn{4}{|c|}{ Trial 2 } \\
$\begin{array}{c}\text { Previous Voltage } \\
\text { Comparison (Iteration 1) }\end{array}$ & $\begin{array}{c}\text { Previous Voltage } \\
\text { Comparison (Iteration 2) }\end{array}$ & $\begin{array}{c}\text { Previous Voltage } \\
\text { Comparison (Iteration 3) }\end{array}$ & $\begin{array}{c}\text { Lowest } \\
\text { Number }\end{array}$ \\
\hline 2.5 & 2.2 & 2.8 & 2.2 \\
\hline $\begin{array}{c}\text { Next Voltage } \\
\text { Comparison (Iteration 1) }\end{array}$ & $\begin{array}{c}\text { Next Voltage } \\
\text { Comparison (Iteration 2) }\end{array}$ & $\begin{array}{c}\text { Next Voltage Comparison } \\
\text { (Iteration 3) }\end{array}$ & $\begin{array}{c}\text { Lowest } \\
\text { Number }\end{array}$ \\
\hline 0.9 & 2.4 & 0.7 & 0.7 \\
\hline \multicolumn{4}{r|}{ Result: Voltage Increases to 2.4V } \\
\hline
\end{tabular}

Table 4-42: Previous and Next Voltage Comparisons for 3 Iterations for the 6V TV (Trial 3)

\begin{tabular}{|c|c|c|c|}
\hline \multicolumn{4}{|c|}{ Trial 3 } \\
\hline $\begin{array}{c}\text { Previous Voltage } \\
\text { Comparison (Iteration 1) }\end{array}$ & $\begin{array}{c}\text { Previous Voltage } \\
\text { Comparison (Iteration 2) }\end{array}$ & $\begin{array}{c}\text { Previous Voltage } \\
\text { Comparison (Iteration 3) }\end{array}$ & $\begin{array}{c}\text { Lowest } \\
\text { Number }\end{array}$ \\
\hline 0.6 & 0.5 & 1.3 & 0.5 \\
\hline $\begin{array}{c}\text { Next Voltage } \\
\text { Comparison (Iteration 1) }\end{array}$ & $\begin{array}{c}\text { Next Voltage } \\
\text { Comparison (Iteration 2) }\end{array}$ & $\begin{array}{c}\text { Next Voltage Comparison } \\
\text { (Iteration 3) }\end{array}$ & $\begin{array}{c}\text { Lowest } \\
\text { Number }\end{array}$ \\
\hline 0.6 & 0.8 & 0.9 & 0.6 \\
\hline \multicolumn{4}{|c|}{ Result: Voltage stays at 2.5V } \\
\hline
\end{tabular}

Table 4-43: Previous and Next Voltage Comparisons for 3 Iterations for the 6 V TV (Trial 4)

\begin{tabular}{|c|c|c|c|}
\hline \multicolumn{4}{|c|}{ Trial 4 } \\
\hline $\begin{array}{c}\text { Previous Voltage } \\
\text { Comparison (Iteration 1) }\end{array}$ & $\begin{array}{c}\text { Previous Voltage } \\
\text { Comparison (Iteration 2) }\end{array}$ & $\begin{array}{c}\text { Previous Voltage } \\
\text { Comparison (Iteration 3) }\end{array}$ & $\begin{array}{c}\text { Lowest } \\
\text { Number }\end{array}$ \\
\hline 3.6 & 4.4 & 6.2 & 3.6 \\
\hline $\begin{array}{c}\text { Next Voltage } \\
\text { Comparison (Iteration 1) }\end{array}$ & $\begin{array}{c}\text { Next Voltage } \\
\text { Comparison (Iteration 2) }\end{array}$ & $\begin{array}{c}\text { Next Voltage Comparison } \\
\text { (Iteration 3) }\end{array}$ & $\begin{array}{c}\text { Lowest } \\
\text { Number }\end{array}$ \\
\hline 4.2 & 4.7 & 4 & 4 \\
\hline \multicolumn{4}{|c|}{ Result: Voltage stays 2.2V } \\
\hline
\end{tabular}


Table 4-44: Previous and Next Voltage Comparisons for 3 Iterations for the 6V TV (Trial 5)

\begin{tabular}{|c|c|c|c|}
\hline \multicolumn{4}{|c|}{ Trial 5 } \\
$\begin{array}{c}\text { Previous Voltage } \\
\text { Comparison (Iteration 1) }\end{array}$ & $\begin{array}{c}\text { Previous Voltage } \\
\text { Comparison (Iteration 2) }\end{array}$ & $\begin{array}{c}\text { Previous Voltage } \\
\text { Comparison (Iteration 3) }\end{array}$ & $\begin{array}{c}\text { Lowest } \\
\text { Number }\end{array}$ \\
\hline 4.6 & 2.6 & 3 & 2.6 \\
\hline $\begin{array}{c}\text { Next Voltage } \\
\text { Comparison (Iteration 1) }\end{array}$ & $\begin{array}{c}\text { Next Voltage } \\
\text { Comparison (Iteration 2) }\end{array}$ & $\begin{array}{c}\text { Next Voltage Comparison } \\
\text { (Iteration 3) }\end{array}$ & $\begin{array}{c}\text { Lowest } \\
\text { Number }\end{array}$ \\
\hline 3.9 & 5.7 & 4.7 & 3.9 \\
\hline \multicolumn{4}{|c|}{ Result: Voltage Stays the same at 2.1V } \\
\hline
\end{tabular}

In summary, each method discussed earlier characterizes the concept of a "smart" wall plug because the methods can predict an appliance's behavior. Furthermore, the methods can detect the appliance's input voltage rating so that the wall plug can supply the appropriate voltage for the appliance. The initial design for the "smart" wall plug to determine an appliance's input voltage rating is Method \#1, where if current exists at the input of the appliance, then the appliance is on. Method \#1 is not fully valid because the $9 \mathrm{~V}$ radio and $6 \mathrm{~V}$ TV have current at the input, even when the appliance is not operating. Method \#2 is developed to improve Method \#1, where the microcontroller takes the difference of two currents for two output voltages to determine the "jump." The "jump" indicates when the appliance is on and that information can be used to tell the microcontroller to stop supplying voltage to the appliance. Because output current fluctuates, it is difficult to determine a condition for the microcontroller to know when to stop supplying voltage. Therefore, Method \#3 is created to accurately define Method \#2, where the microcontroller records 10 trials of the fluctuating current. By observing the behavior of the current, it is assumed that current "stabilizes" at the appliance's rated voltage. Current stability is defined when two different currents have a difference of 0,1 , or 2 for at least 8 trials out of the 10 trials. Method \#3 is successful for detecting the minimum input voltage rating for all 3 appliances, but the "smart" plug's goal is to find the rated voltage. To improve 
Method \#3, Method \#4 uses an accuracy algorithm where the microcontroller increases the output voltage to meet the appliance's voltage rating (assuming that the microcontroller knows the minimum rated voltage). Test trials are conducted and show that the accuracy algorithm does not increase the voltage when necessary or supply over the voltage rating. Therefore, Method \#4 must be improved upon further investigation. 


\section{CHAPTER 5: CONCLUSIONS AND RECOMMENDATIONS}

In this thesis, a method to achieve a "smart" DC wall plug is presented. The proposed wall plug enables direct connection between the main $48 \mathrm{~V} \mathrm{DC}$ bus of the DC House to any voltage level DC electrical appliances such as cell phone charger, tablet charger, radio, fan and TV. The output voltage of the dc-dc converter employed by the proposed wall plug automatically adjusts to any load voltage required to operate the load. Based on the data collected from various DC appliances, the proposed DC wall plug has its output range between $5 \mathrm{~V}$ to $15 \mathrm{~V}$. The output voltage adjustment of the wall plug is done by incorporating output current sensing mechanism in conjunction with a digital resistor in the feedback path of the buck converter used in the wall

plug. Four algorithms were developed and tested to demonstrate the functionality of the proposed wall plug as well as to attempt improvement on the accuracy of the voltage targeted by the proposed wall plug. A total of three DC appliances were tested: a $12 \mathrm{~V}$ radio, a 9V radio, and a 6V TV. Each appliance holds different characteristics and behaviors; therefore research, design, and test were necessary to determine the universal behavior of the wall plug.

Results of the tests conducted on the proposed DC wall plug show that the wall plug successfully outputs sufficient voltage, easily at the minimum voltage level, to operate the three appliances being tested. More specifically for the $9 \mathrm{~V}$ radio, the wall plug is able to meet its rated voltage. This is not the case for the $12 \mathrm{~V}$ radio and the $6 \mathrm{~V}$ radio where the proposed wall-plug stops at slightly higher than the minimum voltage requirement which is still enough to operate both appliances. This may easily be improved by increasing percentage amount of the voltage outputted by the wall plug once the wall plug finds the minimum voltage. This, however, may run into the risk of providing a voltage exceeding the maximum rating of the appliance. 
Further recommendations and improvements are needed to acquire better operation and accuracy than the current design. For example, the present wall plug design has the $15 \mathrm{~V}$ voltage limit which can be made higher by designing a dc-dc converter or using an evaluation board that can provide a larger range. This is important since some dc load operates at larger than $15 \mathrm{~V}$ nominal voltage, and in turn will make the proposed dc wall plug more universal. The digital potentiometer with lesser value than the one currently used (e.g. $1 \mathrm{k} \Omega$ digital potentiometer). This means more digital steps can be achieved such that a better step increase of $0.1 \mathrm{~V}$ steps can be provided instead of the $0.5 \mathrm{~V}$ steps found in the present design. In turn, this will enable the proposed wall plug to yield a more accurate output voltage required by the load. Improved accuracy of the proposed wall plug may also be obtained by utilizing a better algorithm when sensing the output current and adjusting the output voltage. Further tests should also be conducted on more dc appliances to verify the functionality of the wall plug. 


\section{BIBLIOGRAPHY}

[1] Chaidez, Jessica. "DC House Modeling and System Design." Electrical Engineering. Digital Commons@Cal Poly, June 2011. Web.01 Dec. 2012.

$<$ http://digitalcommons.calpoly.edu/eesp/117/>.

[2] Crowfoot, Joseph. "Design and Modeling of the Cal Poly DC House Power Distribution System." Electrical Engineering. Digital Commons @ Cal Poly, June 2011. Web. 01 Dec. 2012. $<$ http://digitalcommons.calpoly.edu/theses/523/>.

[3] Perez, Luis, and Hao Ming Mai. "Photovoltaic System Design for DC House." Electrical Engineering. Digital Commons @ Cal Poly, June 2011. Web. 01 Dec. 2012.

$<$ http://digitalcommons.calpoly.edu/eesp/87/>.

[4] Lim, Evan, and Samson Liu. "Wind Power Generator Design for the DC House Project." Electrical Engineering. Digital Commons @ Cal Poly, June 2011. Web. 01 Dec. 2012. $<$ http://digitalcommons.calpoly.edu/eesp/78/>.

[5] Kwan, Dennis, and Mitchell Krug. "Hydro-Electric Generation System for the DC House Project." Electrical Engineering. Digital Commons @ Cal Poly, June 2011. Web. Nov. 2012. $<$ http://digitalcommons.calpoly.edu/eesp/71/>.

[6] Goguely, Louis, and Brandon Hayes. "Bicycle Power Generator Design for DC House: Off Grid Energy Solutions." The DC House Project. N.p., June 2011. Web. Nov. 2012.

$<$ http://www.calpoly.edu/ taufik/dchouse/download/GoguelyHayes.pdf>.

[7] Wong, Taffy. "A Multiple-Input Single-Output DC-DC Converter for the DC House Project." Digital Commons @ Cal Poly. N.p., Oct. 2011. Web. Nov. 2012.

$<$ http://digitalcommons.calpoly.edu/theses/632/>.

[8] Detmers, Michael, and Tyler Blauvelt. "Variable DC Voltage Wall Outlet for The DC House Project." Digital Commons @ Cal Poly. Cal Poly, June 2011. Web. 08 Oct. 2012.

$<$ http://digitalcommons.calpoly.edu/eesp/79/>.

[9] Jong, Owen. "Multiple Input Single Output DC-DC Converter for the DC House Project." The DC House Project. N.p., June 2012. Web. 01 Dec. 2012.

<http://www.calpoly.edu/ taufik/dchouse/projects.html>.

[10] Lant, Dylan, and Chenxi Zhang. "12 Volt Wall Outlet for The DC House Project." Digital Commons @ Cal Poly. N.p., June 2012. Web. Nov. 2012.

$<$ http://digitalcommons.calpoly.edu/eesp/153/>.

[11] Varsh, William, and Jeffrey Healy. "Human Powered Generation - Seesaw: A DC House Project." Digital Commons @ Cal Poly. N.p., June 2012. Web. Nov. 2012.

$<$ http://digitalcommons.calpoly.edu/eesp/151/>. 
[12] Carrillo, Ervin. "Equating a Car Alternator with the Generated Voltage Equation." Digital Commons @ Cal Poly. N.p., June 2012. Web. Nov. 2012.

$<$ http://digitalcommons.calpoly.edu/eesp/137/>.

[13] Cabaj, Mark. "DC House Model Design and Construction." Digital Commons @ Cal Poly. N.p., June 2012. Web. Nov. 2012. <http://digitalcommons.calpoly.edu/eesp/156/>.

[14] Liang, Kent. "Design of DC Light Bulb for the DC House Project." Digital Commons @ Cal Poly. N.p., June 2012. Web. Nov. 2012. <http://digitalcommons.calpoly.edu/theses/742/>.

[15] Hefner, Andrew, and Antonio Magdaleno. "Cell Phone Charger for the DC House Project." Digital Commons @ Cal Poly. N.p., June 2012. Web. Nov. 2012.

$<$ http://digitalcommons.calpoly.edu/eesp/148/>.

[16] Taufik. "The DC House Project." The DC House Project. N.p., n.d. Web. 01 Dec. 2012. $<$ http://www.calpoly.edu/ taufik/dchouse/>.

[17] Msnbc.com. "Could You Live without Electricity?" Msnbc.com. Msnbc Digital Network, 22 Apr. 2010. Web. 05 Oct. 2012. <http://www.msnbc.msn.com/id/36712257/ns/world_newsworld_environment/t/could-you-live-without-electricity/>.

[18] "Energy Poverty: The Missing Millennium Development Goal?" IEA. N.p., n.d. Web. 05 Oct. 2012. <http://www.iea.org/index_info.asp?id=1847>.

[19] Techakittiroj, K.; Patumtaewapibal, S.; Wongpaibool, V.; Threevithayanon, W.; , "Roadmap for implementation of DC system in future houses," Harmonics and Quality of Power, 2008.

ICHQP 2008. 13th International Conference on, vol., no., pp.1-5, Sept. 28 2008-Oct. 12008 doi: 10.1109/ICHQP.2008.4668827

URL: http://ieeexplore.ieee.org/stamp/stamp.jsp?tp=\&arnumber=4668827\&isnumber $=4668740$

[20] N. Rasmuseen, “AC and DC Power Distribution for Data Centers,” APC

White Paper \#63.

URL: http://www.apcmedia.com/salestools/SADE-5TNRLG_R6_EN.pdf

[21] Techakittiroj, K.; , "Electrical plug and outlet for the DC distribution system in buildings," Control, Automation and Systems, 2008. ICCAS 2008. International Conference on , vol., no., pp.2667-2670, 14-17 Oct. 2008

doi: 10.1109/ICCAS.2008.4694212

URL: http://ieeexplore.ieee.org/stamp/stamp.jsp?tp=\&arnumber=4694212\&isnumber=4694179

[22] “LM5117/LM5117Q Wide Input Range Synchronous Buck Controller with Analog Current Monitor," Technical Datasheet. April 2012. <http://www.ti.com/lit/ds/symlink/lm5117.pdf>

[23] Lee, Eric, National Semiconductor, "LM5117 Evaluation Board," Technical Datasheet. May 25, 2011. < http://www.ti.com/lit/ug/snva466a/snva466a.pdf>

[24] "Arduino Uno." Arduino. N.p., n.d. Web. Nov. 2012.

<http://www.arduino.cc/en/Main/arduinoBoardUno>. 
[25] "Arduino - AnalogRead." Arduino. N.p., n.d. Web. Oct. 2012.

$<$ http://arduino.cc/en/Reference/analogRead $>$.

[26] "AD5204/AD5206." 4-/6-Channel Digital Potentiometers. Analog Devices, 2010. Web. Oct. 2012. <http://www.analog.com/static/imported-files/data_sheets/AD5204_5206.pdf>.

[27] Igoe, Tom. "Arduino - SPI." Arduino. N.p., 10 Aug. 2010. Web. 29 Nov. 2012. $<$ http://arduino.cc/en/Reference/SPI 


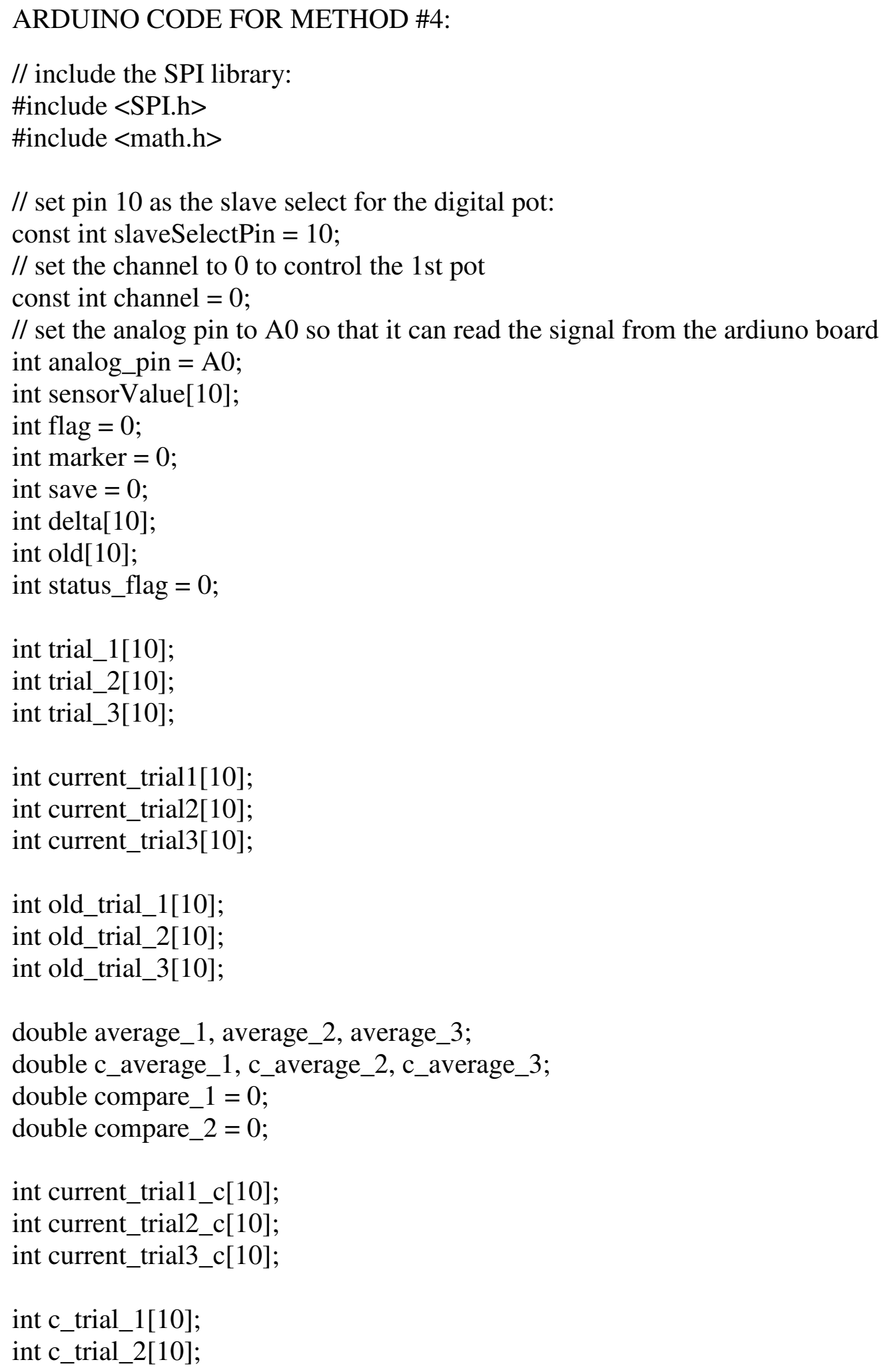


int c_trial_3[10];

//int trial_4[10]; //Add Later

// int trial_5[10]; //Add later

void $\operatorname{setup}()\{$

// set the slaveSelectPin as an output:

pinMode (slaveSelectPin, OUTPUT);

// initialize SPI:

SPI.begin();

// initialize serial communication at 9600 bits per second:

Serial.begin(9600);

\}

$\operatorname{void} \operatorname{loop}()\{$

//Sample the 10 analog pins inputs for one voltage

//Store them into an array

//Compare all voltages and take the common voltage and store into variable

//Take the "2nd" Voltage and subtract from the "1st" Voltage and store this into variable

//Have a condition where it checks the variable and see if it's dramatically bigger than the previous number

$/ /($ Going to have to take the real digital values for the current) -Must test in lab

//(Must determines the "jump") - See what values look different - Record all values on excel

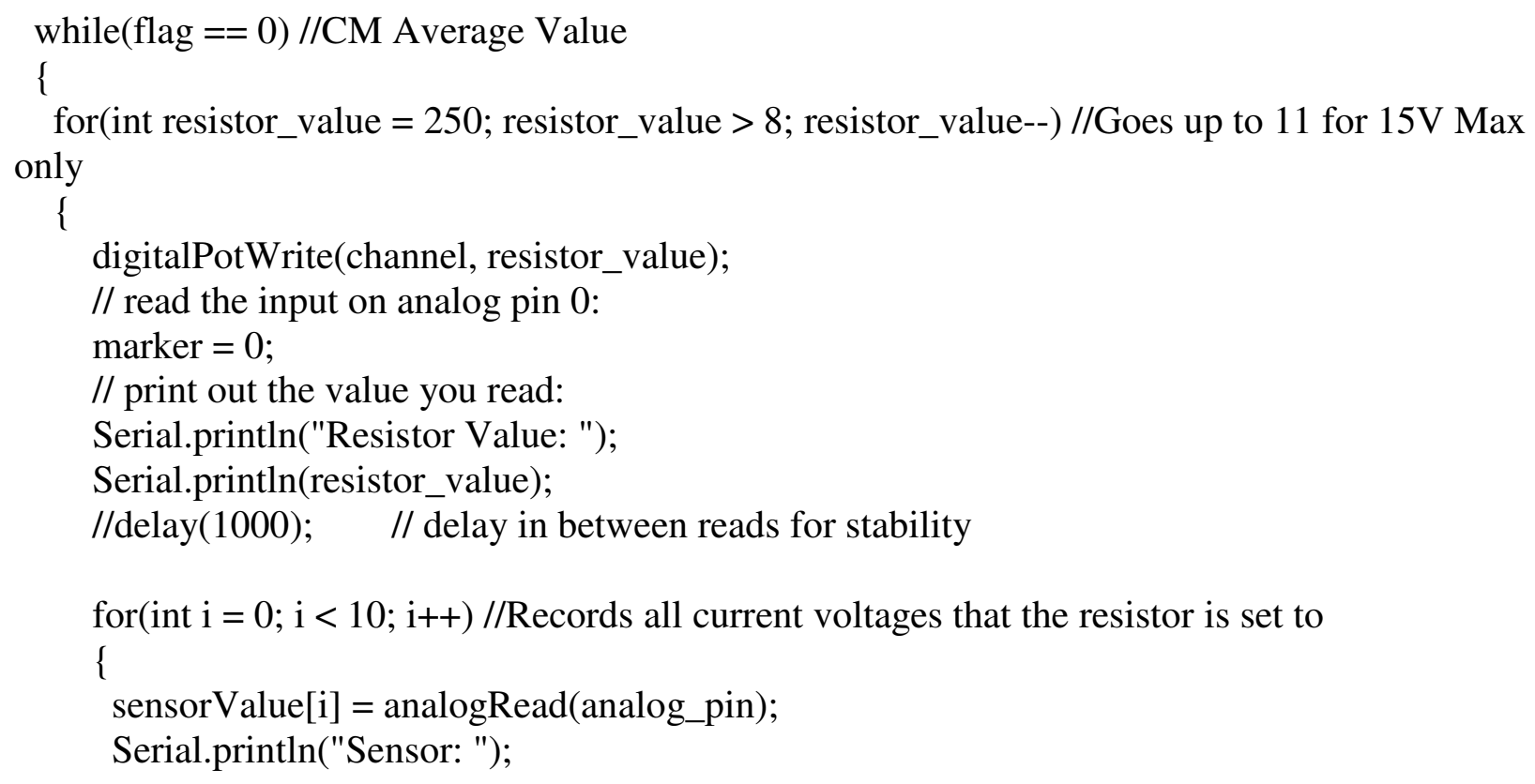




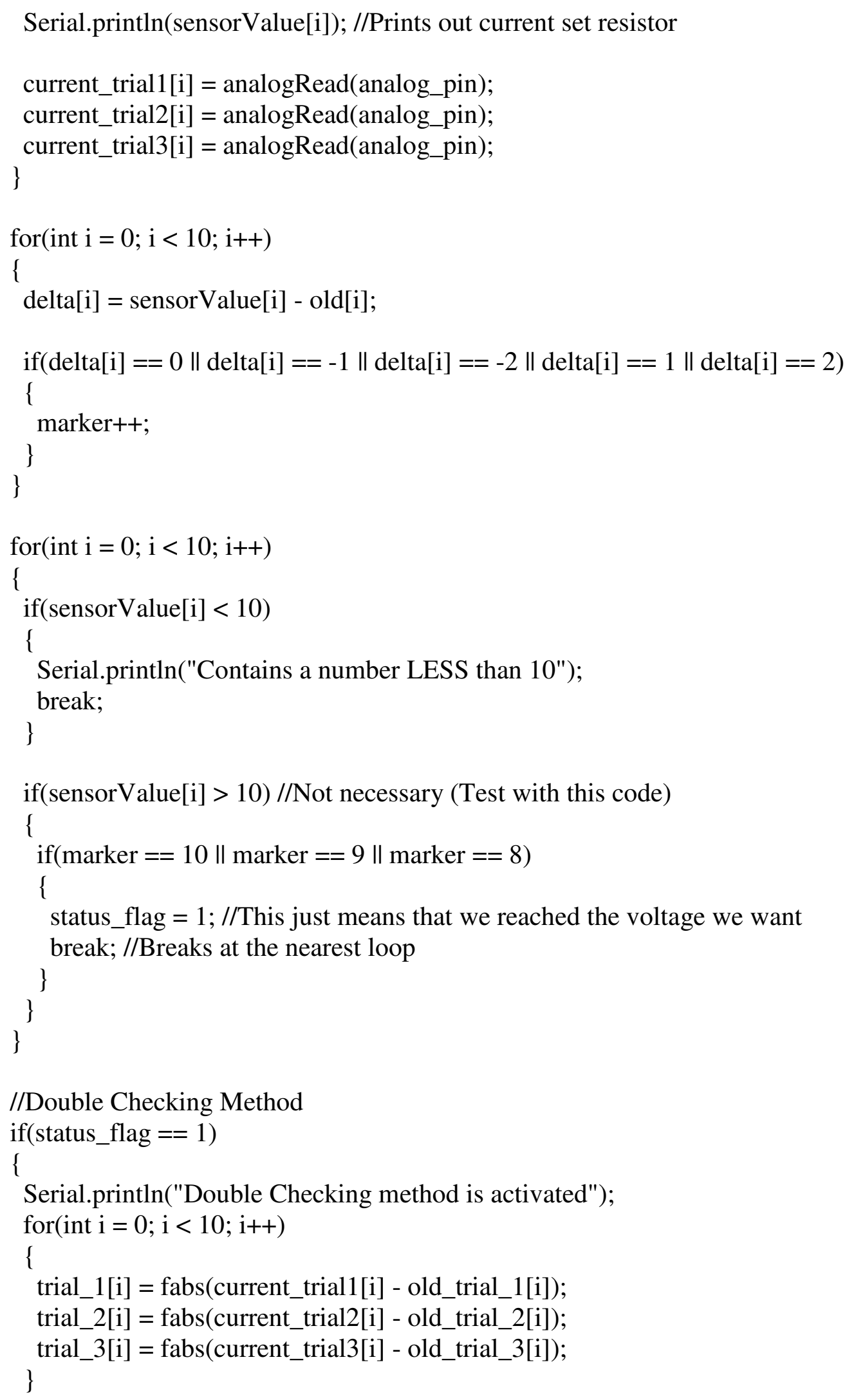


//Case 1: Voltage before

average_1 $=($ trial_1[0] + trial_1[1] + trial_1[2] + trial_1[3] + trial_1[4] + trial_1[5] + trial_1[6] + trial_1[7] + trial_1[8] + trial_1[9]);

average_1 = (average_1 / 10);

Serial.println(average_1);

average_2 $=$ trial_2 $[0]+$ trial_2[1] + trial_2[2] + trial_2[3] + trial_2[4] + trial_2[5] + trial_2[6] + trial_2[7] + trial_2[8] + trial_2[9];

average_2 = (average_2 / 10);

Serial.println(average_2);

average_3 $=$ trial_3[0] + trial_3 $[1]+$ trial_3 $[2]+$ trial_3[3] + trial_3 $[4]+$ trial_3[5] + trial_3[6] + trial_3[7] + trial_3[8] + trial_3[9];

average_3 = (average_3 / 10);

Serial.println(average_3);

//Compare the three numbers \& takes the lowest number

if(average_1 < average_2)

\{

if(average_1 $<$ average_3)

\{

compare_1 = average_1; //1 is the smallest number

\}

else

\{

compare_1 = average_3; //3 is the smallest number

\}

\}

else

\{

if(average_2< average_3)

\{

compare_1 = average_2;

\}

else

\{

compare_1 = average_3;

\}

\}

//Case 2: Voltage after

resistor_value $=$ resistor_value -1 ; //Increases Vout

Serial.println("Vout just increased");

digitalPotWrite(channel, resistor_value);

Serial.println("Newest Resistor Value: ");

Serial.println(resistor_value); 


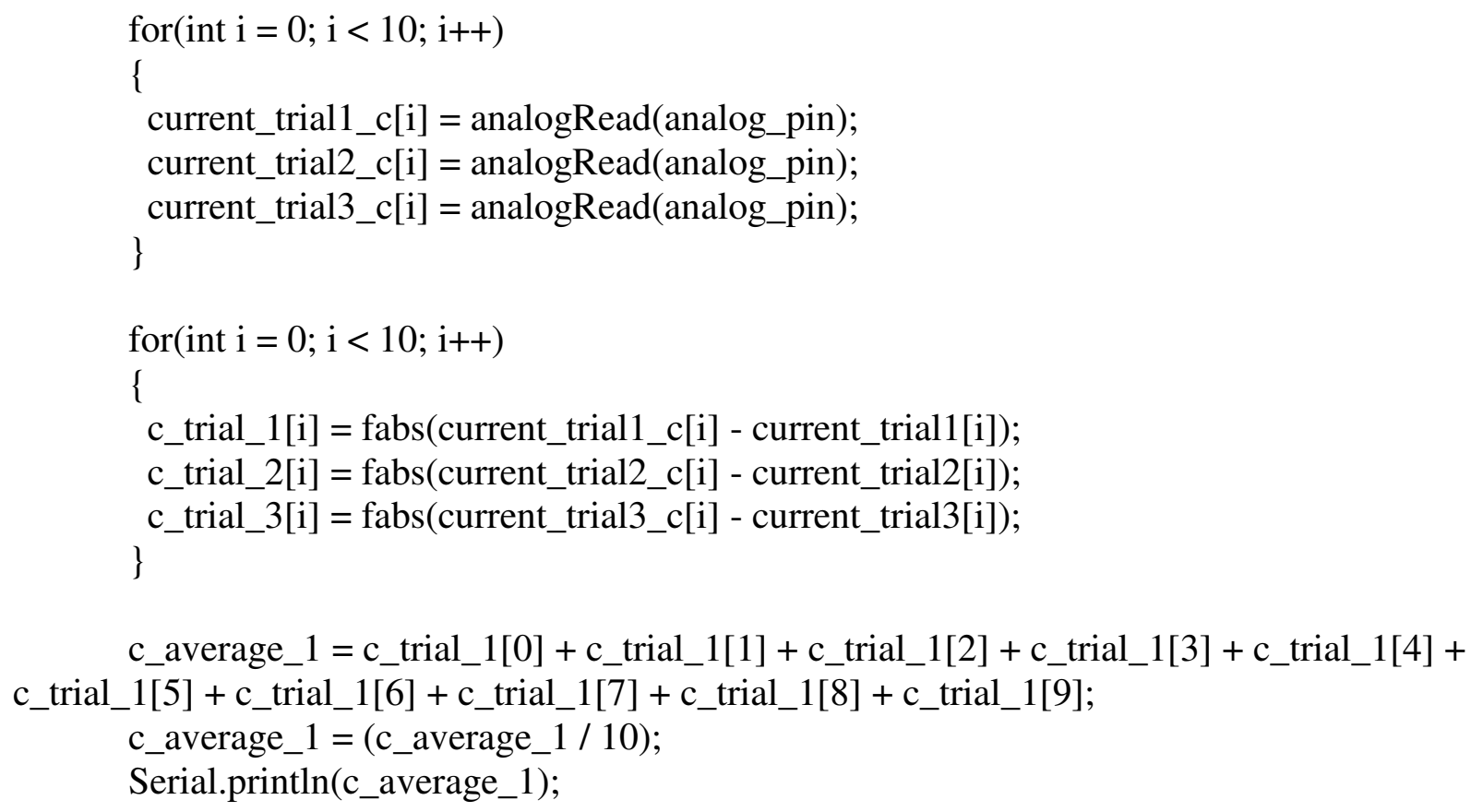

//Compare the three numbers

//Compare the three numbers \& takes the lowest number

if(c_average_1 < c_average_2)

\{

if(c_average_1 < c_average_3)

\{ compare_2 = c_average_1; //1 is the smallest number 


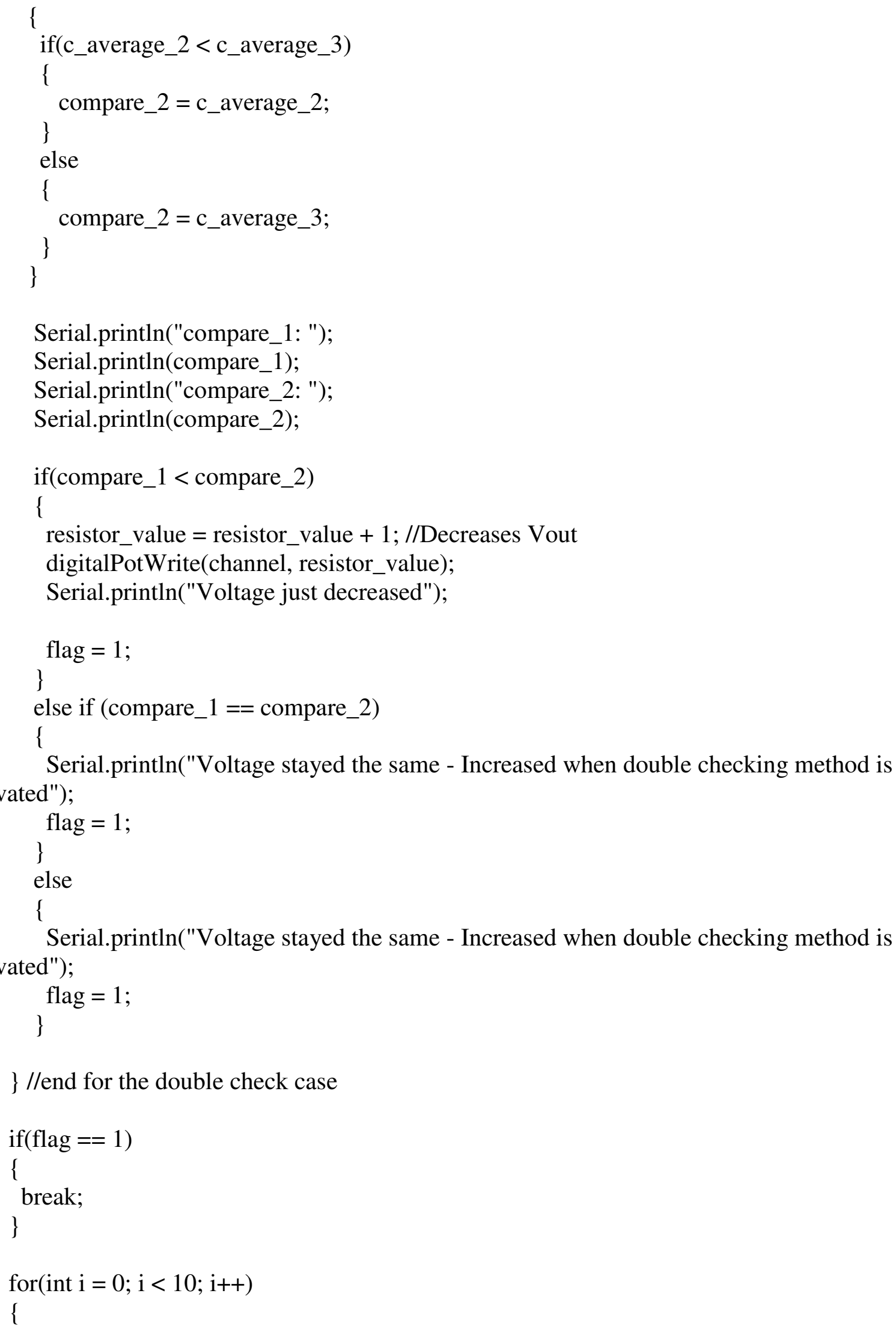

Serial.println("Voltage stayed the same - Increased when double checking method is activated"); 


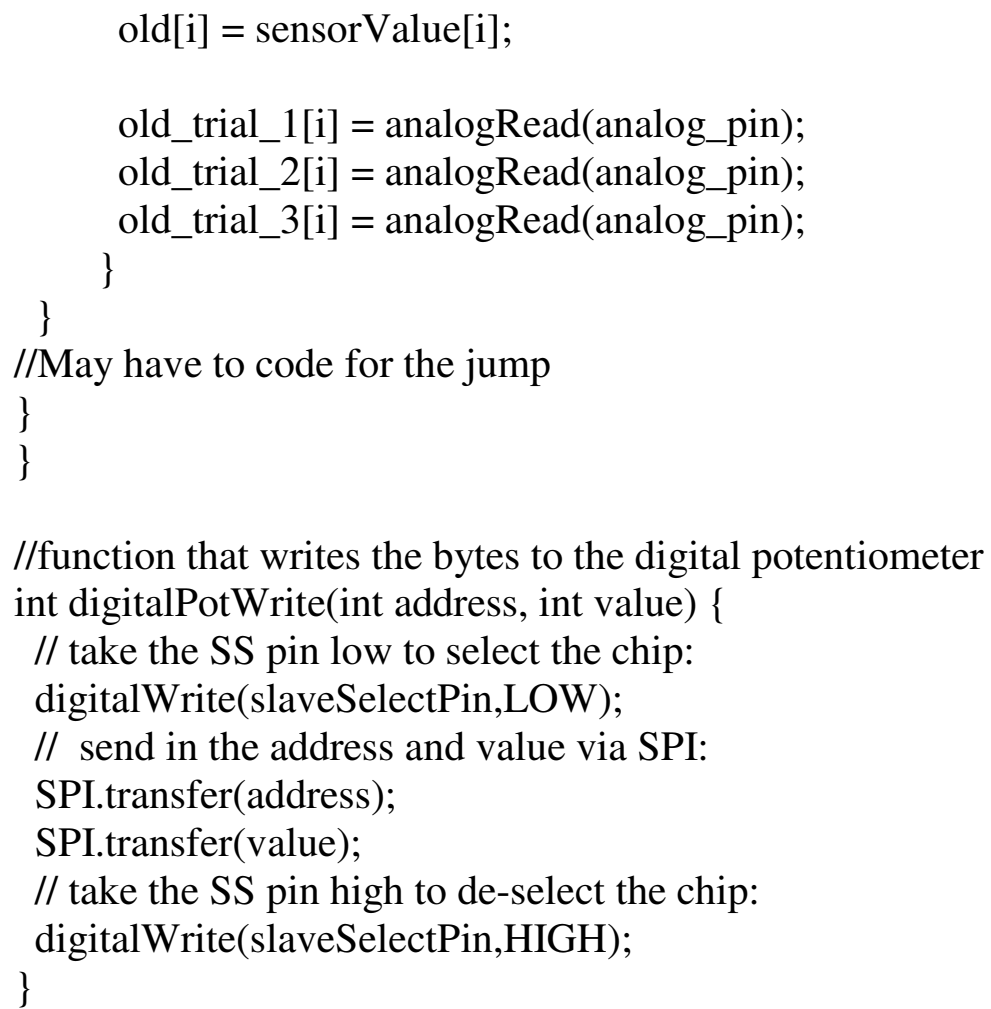

//function that writes the bytes to the digital potentiometer int digitalPotWrite(int address, int value) \{ // take the SS pin low to select the chip: digitalWrite(slaveSelectPin,LOW);

// send in the address and value via SPI:

SPI.transfer(address);

SPI.transfer(value);

// take the SS pin high to de-select the chip: digitalWrite(slaveSelectPin,HIGH); \} 


\section{ARDUINO CODE FOR METHOD \#3:}

// include the SPI library:

\#include <SPI.h>

// set pin 10 as the slave select for the digital pot:

const int slaveSelectPin $=10$;

// set the channel to 0 to control the 1 st pot

const int channel $=0$;

// set the analog pin to A0 so that it can read the signal from the ardiuno board

int analog_pin = A0;

int sensorValue[10];

int flag $=0$;

int marker $=0$;

int save $=0$;

int delta[10];

int old[10];

void $\operatorname{setup}()\{$

// set the slaveSelectPin as an output:

pinMode (slaveSelectPin, OUTPUT);

// initialize SPI:

SPI.begin();

// initialize serial communication at 9600 bits per second:

Serial.begin(9600);

\}

void $\operatorname{loop}()\{$

//Sample the 10 analog pins inputs for one voltage

//Store them into an array

//Compare all voltages and take the common voltage and store into variable

//Take the "2nd" Voltage and subtract from the "1st" Voltage and store this into variable

//Have a condition where it checks the variable and see if it's dramatically bigger than the previous number

$/ /$ (Going to have to take the real digital values for the current) -Must test in lab

//(Must determines the "jump") - See what values look different - Record all values on excel

while(flag ==0) //CM Average Value

\{

for(int resistor_value $=250$; resistor_value $>19$; resistor_value--) $/ /$ Goes up to 11 for $15 \mathrm{~V}$ Max only 
digitalPotWrite(channel, resistor_value);

$/ /$ read the input on analog pin 0 :

marker $=0$;

// print out the value you read:

Serial.println("Resistor Value: ");

Serial.println(resistor_value);

//delay(1000); // delay in between reads for stability

for(int $\mathrm{i}=0 ; \mathrm{i}<10 ; \mathrm{i}++) / /$ Records all current voltages that the resistor is set to \{

sensorValue[i] = analogRead(analog_pin);

Serial.println("Sensor: ");

Serial.println(sensorValue[i]); //Prints out current set resistor \}

for $($ int $\mathrm{i}=0 ; \mathrm{i}<10 ; \mathrm{i}++)$

\{

delta[i] = sensorValue[i] - old[i];

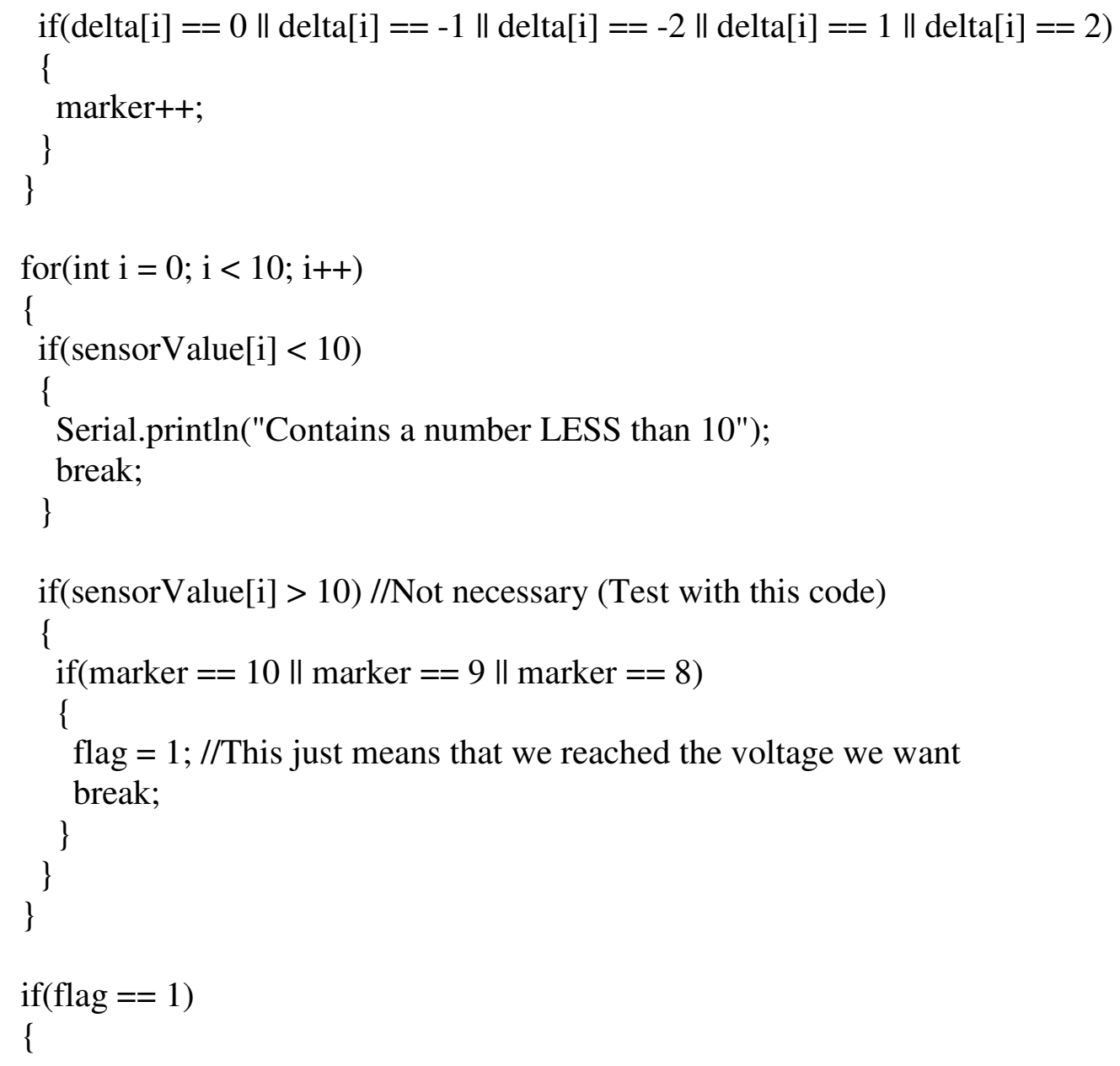




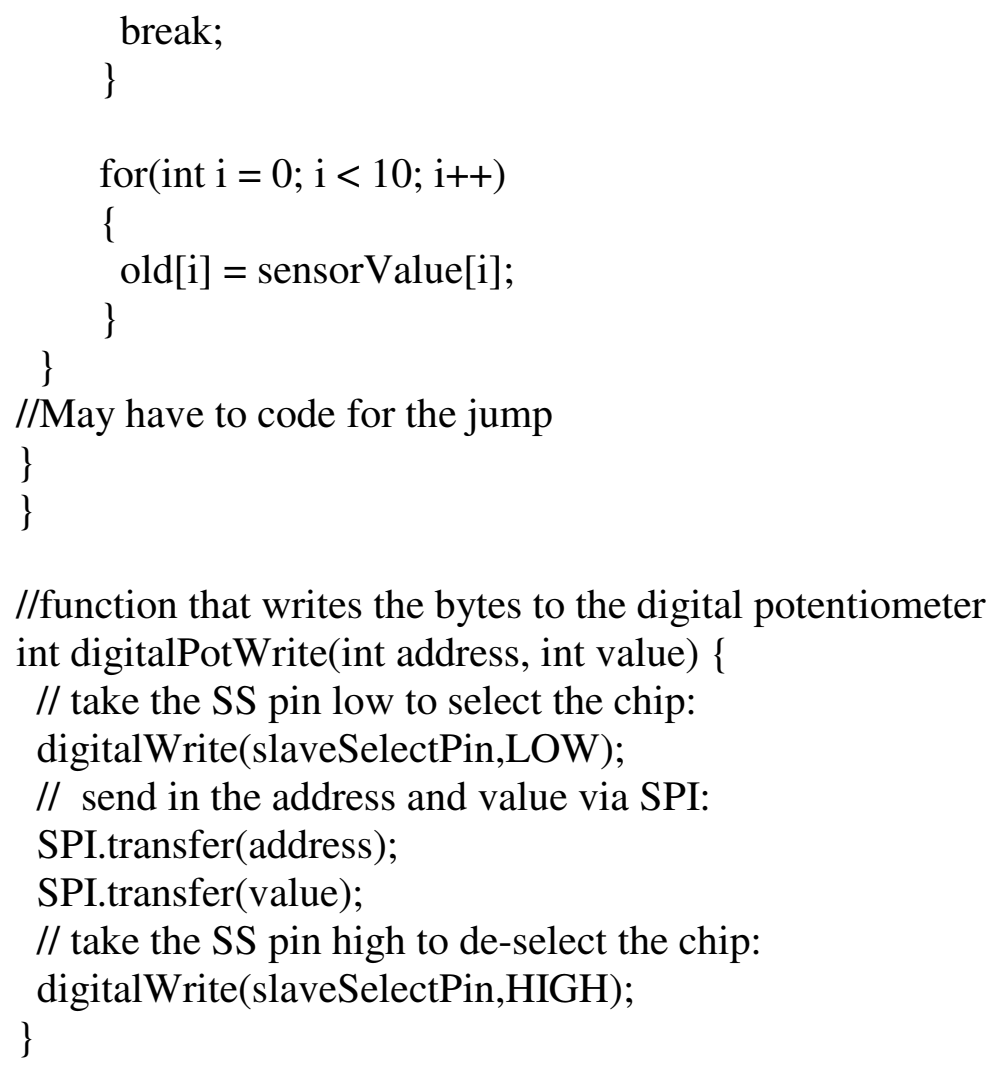

//function that writes the bytes to the digital potentiometer int digitalPotWrite(int address, int value) \{ // take the SS pin low to select the chip: digitalWrite(slaveSelectPin,LOW);

// send in the address and value via SPI:

SPI.transfer(address);

SPI.transfer(value);

// take the SS pin high to de-select the chip: digitalWrite(slaveSelectPin,HIGH); \} 


\section{APPENDIX B: FLOWCHARTS FOR METHOD \#1, \#2, \#3, \& \#4}

Method \#1 Flowchart:

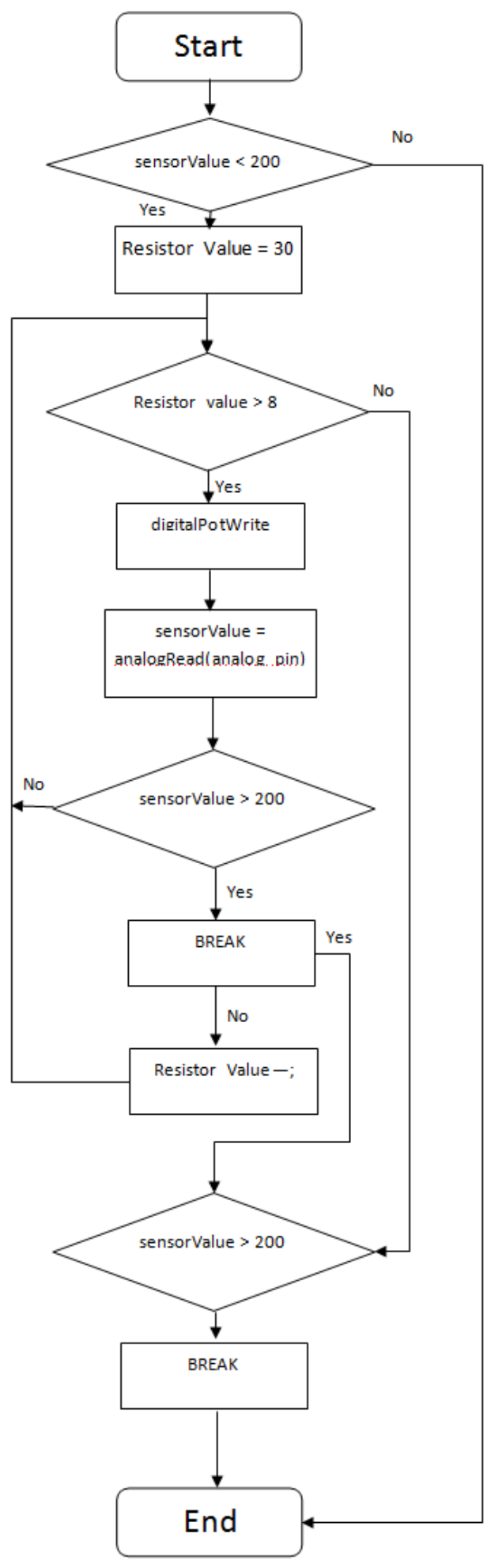


Method \#2 Flowchart:

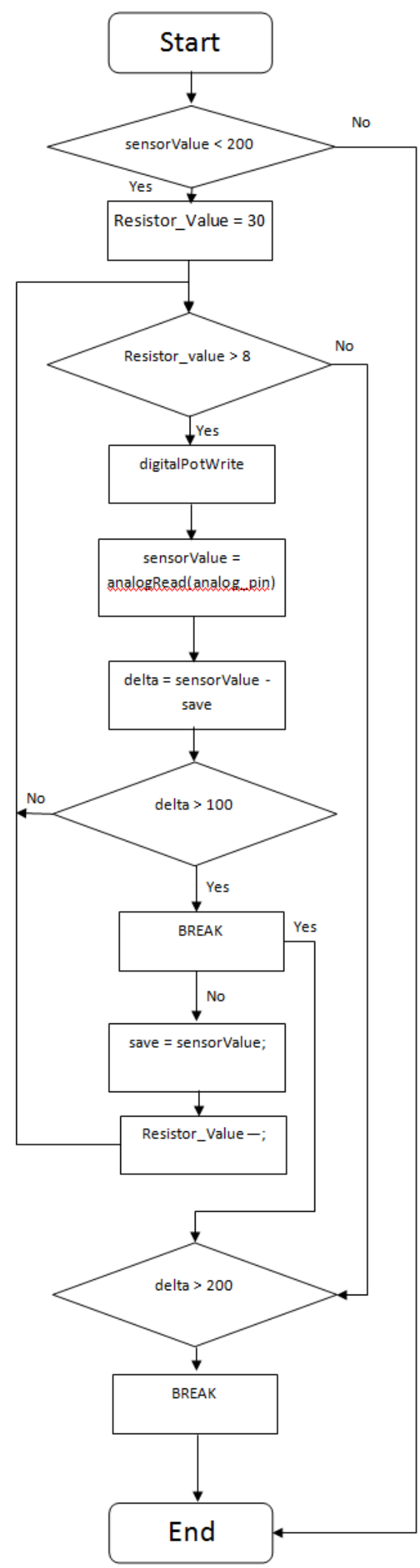


Method \#3 Flowchart:

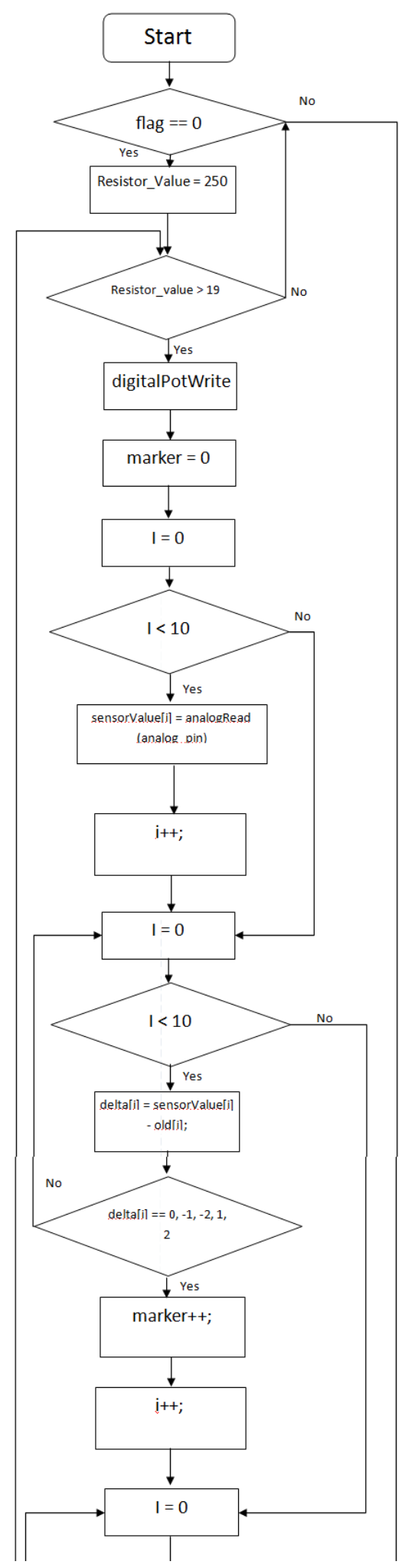


Method \#3 Flowchart (Continued):

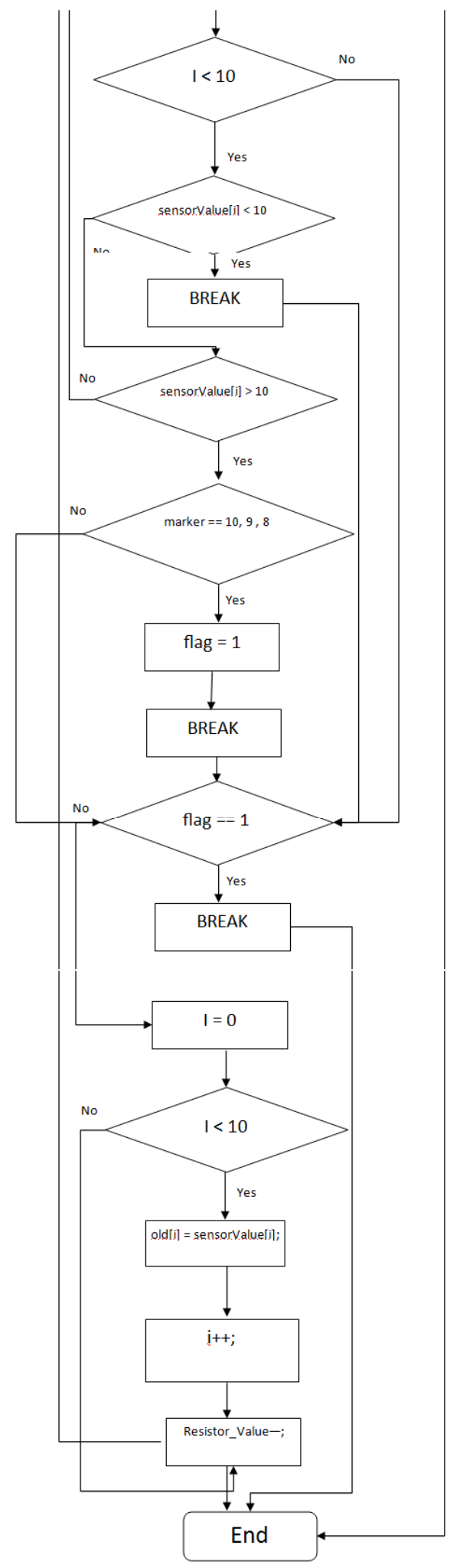


Method \#4 Flowchart:

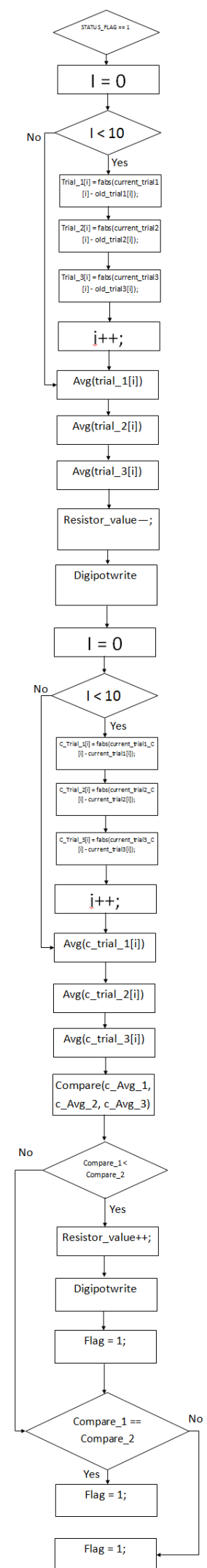

